\title{
New Zealand's Assistance with Invasive Species Management in the Pacific
}

\author{
Simon Lovatt
}

Thesis submitted in partial fulfilment of the Requirements for the Master of International Relations

School of History, Philosophy, Political Science and International Relations

Victoria University of Wellington

March 2011 


\section{Executive Summary}

Invasive species are one of the biggest threats to development and well-being in the Pacific. They have wide-ranging impacts on economies, the environment, and societies; in addition to causing USD $\$ 1.4$ trillion of losses each year. Invasive species are also the primary cause of biodiversity loss on islands which could significantly affect the ecosystem services which Pacific Islanders depend on. Every year New Zealand spends NZD \$500 million on biosecurity, and Australia has spent AUD $\$ 175$ million on a single eradication project. In comparison, in the Pacific there are only six people working fulltime on invasive species issues at a regional level and there is limited funding available.

This thesis assesses the role of four New Zealand agencies that assist with invasive species management in the Pacific: the International Development Group of the Ministry of Foreign Affairs, the Biosecurity New Zealand division of the Ministry of Agriculture and Forestry, the Department of Conservation, and Landcare Research. Together these agencies provide funding, build capacity, offer technical advice, and occasionally implement projects. While there are important gains to New Zealand in assisting the Pacific with invasive species management, such as a reduced biosecurity threat and learning opportunities for staff, the desire to help the region for its own sake is a major driver.

Suggestions for future improvement include having more information on the economic impacts of invasive species in the Pacific, increased coordination between donors, and including invasive species measures in regional trade agreements. It is hoped that New Zealand will continue to play its critical leadership role in invasive species management in the region. 


\section{Acknowledgements}

I would like to thank all participants for their generosity and helpfulness; my supervisor John Leslie and mentor Susan Elliott for their help and guidance; my fellow MIR students; and my partner Jo, without whose patience, support, and endless proof-reading this research would not have been possible.

\section{Disclaimer:}

While every attempt has been made to ensure the accuracy of information in this thesis, any errors or misrepresentations are my own and are entirely unintentional. 


\section{Contents}

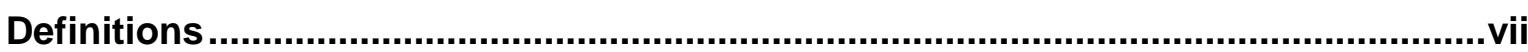

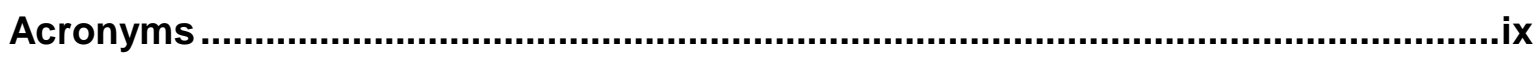

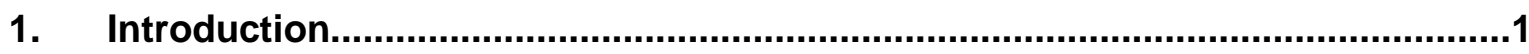

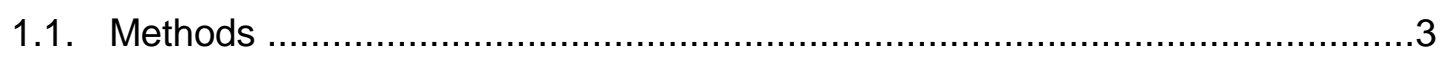

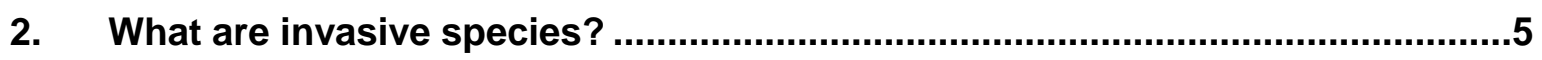

2.1. What makes them invasive? .................................................................

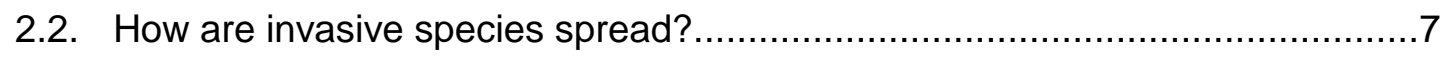

2.3. What are the causes of invasive species? ……………………………....

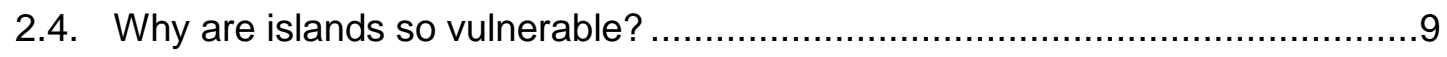

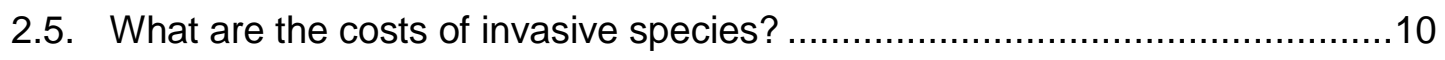

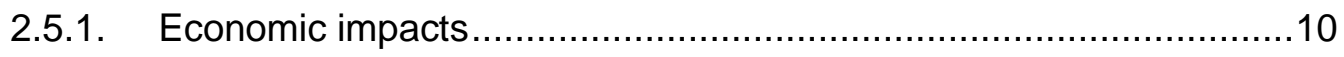

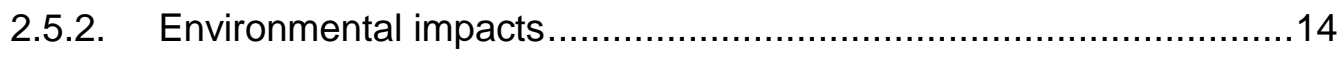

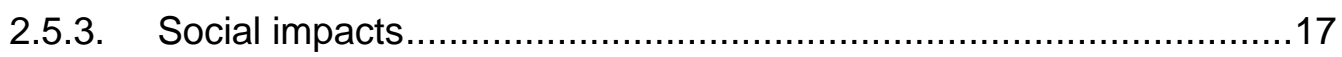

2.6. Climate change and invasive species .....................................................21

2.6.1. How climate change affects invasive species................................22

2.6.2. How invasive species affect climate change ................................23

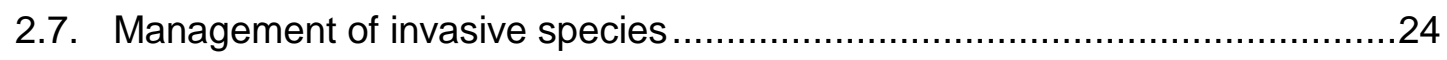

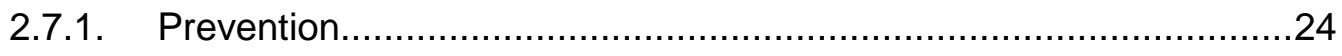

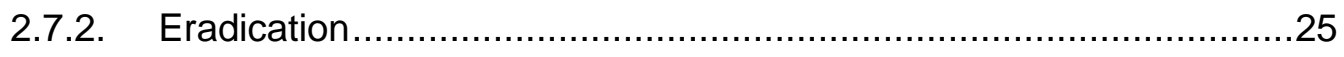

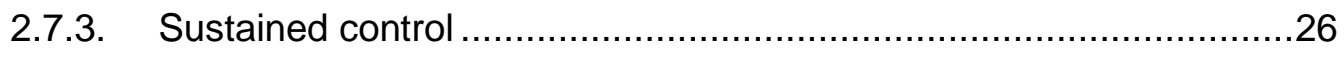

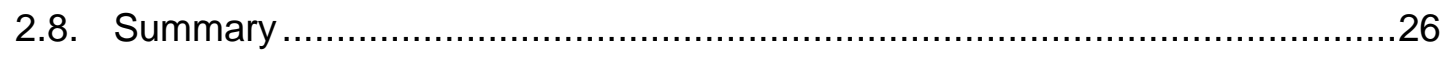

3. Regional architecture for invasive species management in the Pacific ...........28

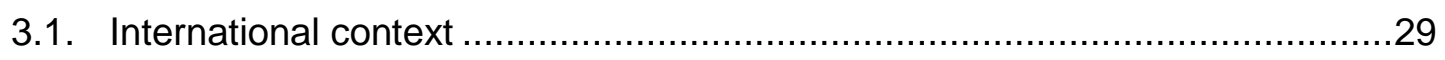

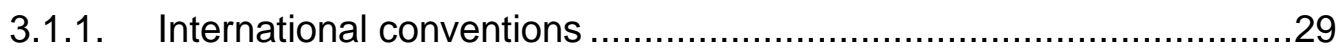


3.1.2. International organisations

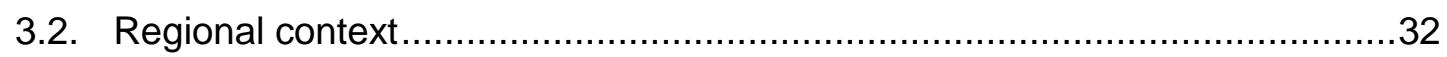

3.2.1. Regional plans and actions strategies ................................... 33

3.2.2. Regional actors and organisations .......................................... 38

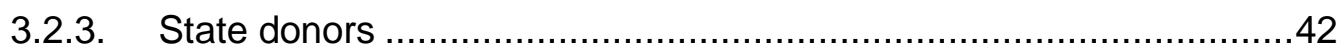

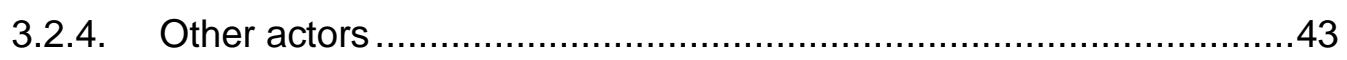

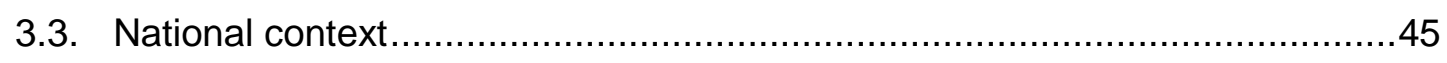

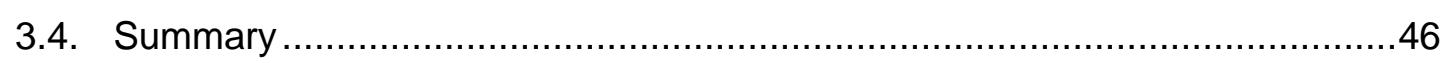

4. The role of New Zealand actors in invasive species management .................47

4.1. International Development Group of the Ministry of Foreign Affairs and Trade

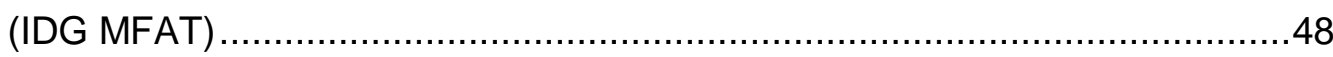

4.1.1. How does IDG MFAT assist with invasive species work in the Pacific?50

4.1.2. Assessing IDG MFAT's aid and leadership role .........................52

4.2. Ministry of Agriculture and Forestry Biosecurity New Zealand (MAFBNZ)......53

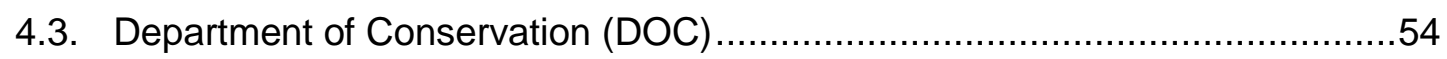

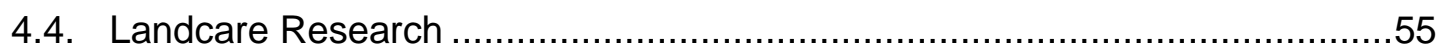

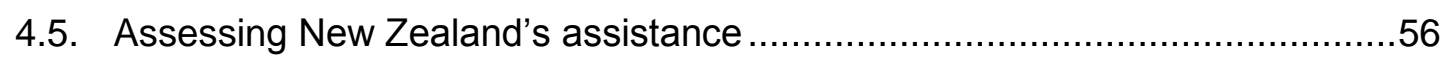

4.5.1. Motivations of New Zealand agencies for assisting the Pacific.........57

4.5.2. How much collaboration is there between New Zealand agencies?.58

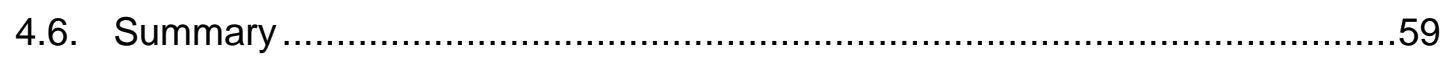

5. Improving invasive species management...............................................60

5.1. Why have invasive species not been given more attention? ......................60

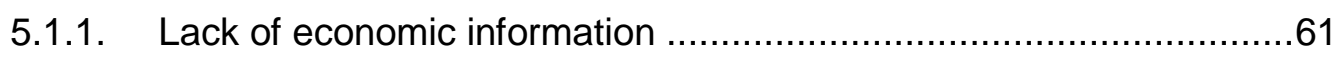

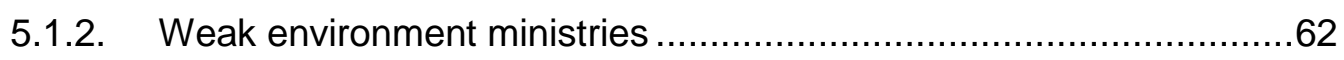

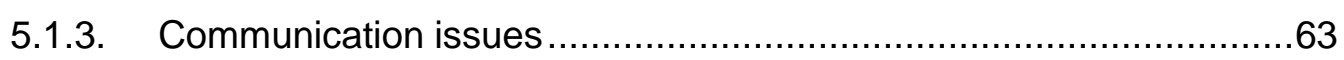

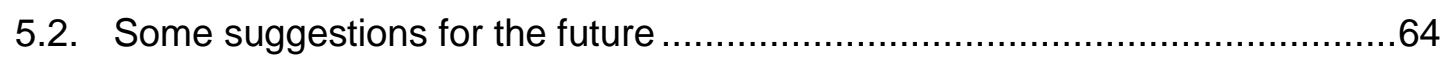

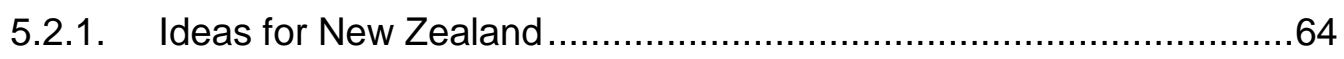

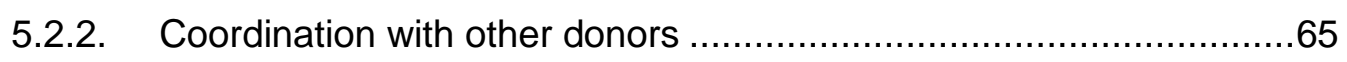




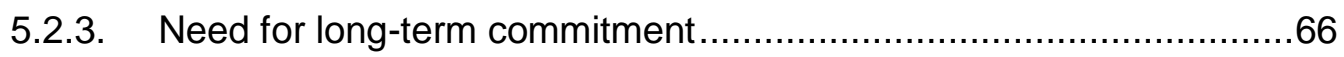

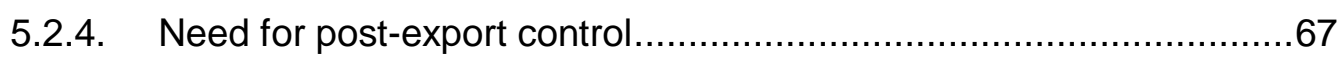

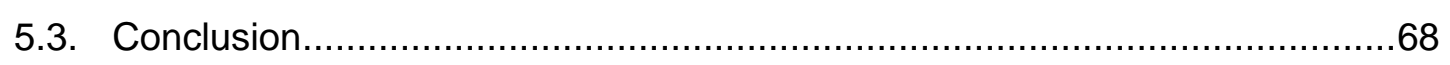

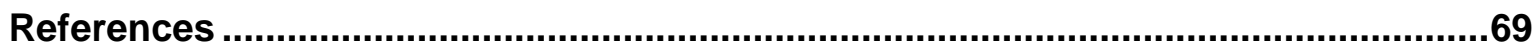

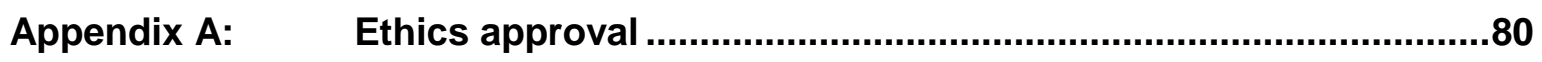

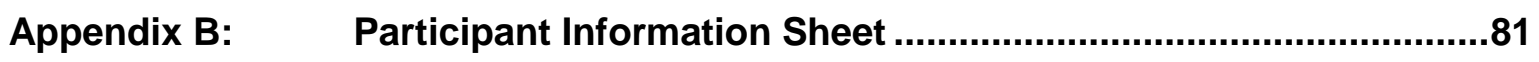

Appendix C: $\quad$ Participant Consent Form ........................................................82

Appendix D: $\quad$ Sample Interview Questions .................................................. 83

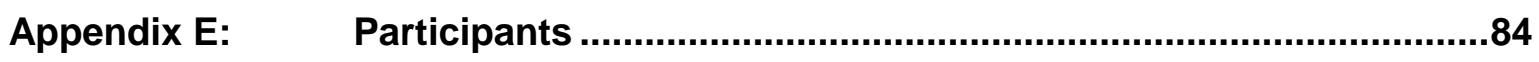




\section{Definitions ${ }^{1}$}

Alien species

Biodiversity

(biological diversity)

Biosecurity

Intentional

introduction

Invasive species
Plants, animals and other organisms taken beyond their natural range by people, intentionally or unintentionally. This term is synonymous with introduced species and I use the two interchangeably.

The variability among living organisms from all sources, including, terrestrial, marine, and other aquatic ecosystems, and the ecological complexes of which they are part: this includes diversity within species, between species, and of ecosystems. A somewhat simpler definition is the totality of all genes, species, and ecosystems of a region.

Preventing the spread of invasive species across international or internal borders, including between islands. This can involve techniques such as quarantine and fumigation.

The deliberate movement of a species outside its natural range by people (such introductions may be authorised or unauthorised).

Introduced species that become destructive to the environment or human interests. $^{2}$ This can also include some native species that proliferate and become destructive following environmental changes caused by human activities. Note, that although this definition covers all species, many invasive species management programmes deal with mainly vertebrates, invertebrates, or weeds. This is synonymous with "invasive alien species" -

\footnotetext{
${ }^{1}$ IUCN/SSC Invasive Species Specialist Group (ISSG), IUCN guidelines for the prevention of biodiversity loss caused by alien invasive species (Gland Switzerland,: International Union for Conservation of Nature (IUCN), February 2000), http://intranet.iucn.org/webfiles/doc/SSC/SSCwebsite/Policy_statements/IUCN_Guidelines_for_the_Prevention_of _Biodiversity_Loss_caused_by_Alien_Invasive_Species.pdf.;

Alan Tye, Guidelines for invasive species management in the Pacific: a Pacific strategy for managing pests, weeds and other invasive species (Apia, Samoa: SPREP, 2009), http://www.sprep.org/att/publication/000699_RISSFinalLR.pdf.

${ }^{2}$ This definition is broader than the Convention on Biological Diversity which only mentions species that threaten native biodiversity. 
although some native species can also become invasive in a new habitat.

Invasive species management

Native species

Pacific

Unintentional introduction
Covers the entire spectrum from prevention (biosecurity), eradication, and sustained control (suppression or containment).

Plants, animals, and other organisms that occur naturally on an island or in a specified area, having either evolved there or arrived there without human intervention.

The Pacific Island Countries and Territories (PICT) that are members of the Secretariat of the Pacific Community: American Samoa, Cook Islands, Federated States of Micronesia, Fiji Islands, French Polynesia, Guam, Kiribati, Marshall Islands, Nauru, New Caledonia, Niue, Northern Mariana Islands, Palau, Papua New Guinea, Pitcairn Islands, Samoa, Solomon Islands, Tokelau, Tonga, Tuvalu, Vanuatu, and Wallis and Futuna.

This list excludes New Zealand, Australia, France, USA, and UK, as well as islands off the coast of North and South America (for example, the Galapagos Islands).

The unintended movement of a species outside its natural range as a result of a species utilising humans or human delivery systems as vectors. 


\section{Acronyms}

\begin{tabular}{ll} 
CBD & Convention on Biological Diversity \\
CEPF & Critical Ecosystem Partnership Fund \\
CII & Cooperative Islands Initiative \\
CNMI & Commonwealth of the Northern Mariana Islands \\
CROP & Council of Regional Organisations of the Pacific \\
DOC & Department of Conservation \\
FSM & Federated States of Micronesia \\
GDP & Gross Domestic Product \\
GEF & Global Environment Facility \\
GISP & Global Invasive Species Programme \\
GNI & Gross National Income \\
IDG MFAT & International Development Group of the Ministry of Foreign Affairs \\
IEAG & and Trade (formerly NZAID) \\
IMO & Island Eradication Advisory Group \\
IPPC & International Maritime Organisation \\
IUCN & International Plant Protection Convention \\
IUCN-ISSG & International Union for the Conservation of Nature \\
MAF & Invasive Species Specialist Group of the International Union for \\
MAFBNZ & Conservation of Nature \\
MDG & Ministry of Agriculture and Forestry \\
MEA & Millennium Development Goals \\
\hline
\end{tabular}




$\begin{array}{ll}\text { NBSAP } & \text { National Biodiversity Strategy Action Plan } \\ \text { NISAP } & \text { National Invasive Species Action Plan } \\ \text { NZAID } & \text { New Zealand Agency for International Development (this is now } \\ & \text { known as IDG MFAT) } \\ \text { ODA } & \text { Official Development Assistance } \\ \text { OECD } & \text { Organisation for Economic Co-operation and Development } \\ \text { OECD-DAC } & \text { Development Assistance Committee of the Organisation for } \\ \text { PAAG } & \text { Economic Co-operation and Development } \\ \text { PAPP } & \text { Pacific Activities Advisory Group } \\ \text { PICT } & \text { Pacific Ant Prevention Programme } \\ \text { PII } & \text { Pacific Island Country and Territory } \\ \text { PILN } & \text { Pacific Invasives Initiative } \\ \text { PIP } & \text { Pacific Invasives Learning Network } \\ \text { PIPA } & \text { Pacific Invasives Partnership } \\ \text { PNG } & \text { Phoenix Islands Protected Area } \\ \text { PPPO } & \text { Papua New Guinea } \\ \text { PSF } & \text { Pacific Plant Protection Organisation } \\ \text { SPC } & \text { Pacific Security Fund } \\ \text { SPREP } & \text { Secretariat of the Pacific Community } \\ \text { SPS } & \text { Secretariat of the Pacific Regional Environment Programme } \\ \text { SSDPF } & \text { Sanitary and Phytosanitary } \\ \text { TPP } & \text { State Sector Development Partnerships Fund } \\ \text { UNEP } & \text { Trans Pacific Partnership } \\ \text { USP } & \text { United Nations Environment Programme } \\ \text { WTO } & \text { Universanisation }\end{array}$




\section{Introduction}

"Far too many governments have failed to grasp the scale of the threat from invasive species. ${ }^{\text {,3 }}$

Achim Steiner, Executive Director, United Nations Environment Programme

The Pacific is one of the most biologically, culturally, and linguistically ${ }^{4}$ diverse regions on the planet. The region contains approximately 30,000 islands ${ }^{5}$ spread over 30 million km ${ }^{2,}{ }^{6}$ and is home to around 8 million people.7 There are 22 Pacific Island Countries and Territories (PICTs) 8 which are divided into three main island groups: Melanesia, Micronesia, and Polynesia.9 PICTs range in size from under 2,000 people (Tokelau and Niue) to Papua New Guinea which has almost 6 million. ${ }^{10}$

Pacific island ecosystems make up one of the world's biodiversity hotspots, with high levels of species that are found nowhere else in the world. ${ }^{11}$ For example, a single reef in the Western Pacific had over 3,000 species of fish which is the highest ever recorded. ${ }^{12}$ This biodiversity, and the ecosystem services which they support, are critical for the well-being of Pacific Islanders; the great majority of whom depend on subsistence agriculture and fishing for their survival. However, the Pacific environment faces a number of challenges including illegal

\footnotetext{
${ }^{3}$ Achim Steiner, "Counting the cost of alien invasions," April 13, 2010, http://news.bbc.co.uk/2/hi/science/nature/8615398.stm.

${ }^{4}$ Peter Hunnam, Lessons in Conservation for People and Projects in the Pacific Islands Region (New York: United Nations Development Programme (UNDP), 2002), 1, www.undp.org.ws/Portals/12/pdf/lessons.pdf.

${ }^{5}$ lbid.

${ }^{6}$ M McIntyre, Pacific Environment Outlook - Special Edition for the Mauritius International Meeting for the 10-year Review of the Barbados Programme of Action for the Sustainable Development of Small Island Developing States (United Nations Environment Programme (UNEP), 2005), 12, http://www.unep.org/pdf/sids/Pacific_EO_final.pdf.

${ }^{7}$ New Zealand Aid Programme, "Pacific countries overview," n.d., http://www.aid.govt.nz/programmes/c-paccountries.html.

${ }^{8}$ American Samoa, Cook Islands, Federated States of Micronesia (FSM), Fiji, French Polynesia, Guam, Kiribati, Marshall Islands, Nauru, New Caledonia, Niue, Northern Mariana Islands (CNMI) Palau, Papua New Guinea (PNG), Pitcairn Islands, Samoa, Solomon Islands, Tokelau, Tonga, Tuvalu, Vanuatu, and Wallis and Futuna. Many of these islands maintain close associations with or are even overseas territories of the USA (American Samoa, FSM, Guam, Marshall Islands, CNMI, and Palau), France (French Polynesia, New Caledonia, and Wallis and Futuna), New Zealand (Cook Islands, Niue, and Tokelau), or the United Kingdom (Pitcairn Islands).

${ }^{9}$ In this thesis Hawaii and the islands off the South American coast, such as the Galapagos Islands, are excluded from the definition of the "Pacific".

${ }^{10}$ New Zealand Agency for International Development (NZAID), Pacific Strategy 2007- 2015: Te Ara Tupu - the pathway of growth / Tackling Poverty in our Region (Wellington, New Zealand: NZAID, June 2008), 11, http://www.aid.govt.nz/programmes/wln-pacific-regional-strategy-2007-2015-full-june08.pdf.

${ }^{11}$ Global Environment Facility (GEF), "GEF-PAS Project Identification Form," 2007, 5, http://www.gefonline.org/ProjectDocs/Pacific Alliance for Sustainability (PAS)/Regional - Prevention, Control -Invasive Alien - GEF ID 3664/10-17-08 PIF document revised ID3664.doc.

12 Mclntyre, Pacific Environment Outlook, 43.
} 
logging, habitat destruction, and overexploitation; ${ }^{13}$ with invasive species being the primary cause of biodiversity loss in the region. ${ }^{14}$

The Pacific also faces significant development challenges. Population densities are high, and the population is expected to double over the next 30 years. ${ }^{15}$ Around half the people in the region live below the poverty line, ${ }^{16}$ and the level of human development (as measured by the Human Development Index), ranges from 0.677 in Tonga to 0.431 in PNG. ${ }^{17,18}$ On the whole, the Pacific is one of the regions least on track to achieve progress in the Millennium Development Goals (the international poverty reduction and development targets agreed to by the United Nations). ${ }^{19}$ Invasive species, with their impacts on food security, human health, economic sectors, and climate change, are expected to put further pressure on the ability of PICTs to meet these development challenges.

Alien species are species that move outside their natural range either with the deliberate assistance of humans (e.g. the international trade of ornamental plants), or unintentionally (e.g. tramp ants "hitchhiking" in shipping containers). Many alien species are beneficial to human well-being: more than $90 \%$ of the world's food supply derives from introduced grasses (wheat, rice, corn), mammals (cattle, sheep, pigs), and birds (chickens and ducks). ${ }^{20}$ However, a small percentage of alien species can become invasive, and when they do they can have severe impacts on the environment, the economy, and society. ${ }^{21}$ One estimate of the global economic cost of invasive species was USD 1.4 trillion, representing $5 \%$ of the world economy at the time. ${ }^{22}$ Islands are especially vulnerable to these impacts, due to their fragile ecosystems, high levels of international trade, and often limited government capacity.

\footnotetext{
13 Ibid., 47.

${ }^{14}$ Millennium Ecosystem Assessment, Ecosystems and Human Well-being: Synthesis (Washington D.C.: Island Press, 2005), 16, http://www.maweb.org/documents/document.356.aspx.pdf.

${ }^{15}$ Mclntyre, Pacific Environment Outlook, 1.

${ }^{16}$ B Coates, "Getting serious about achieving the Millennium Development Goals in the Pacific: Strengthening Economic Development," Policy Quarterly 5, no. 3 (August 2009): 28.

V. Naidu, "Changing Gears on the Millennium Development Goals in Oceania," Policy Quarterly 5, no. 3 (August 2009): 11.

17 United Nations Development Programme (UNDP), Human Development Index and its components (UNDP, 2010), 2-3, http://hdr.undp.org/en/media/HDR_2010_EN_Tables_reprint.pdf.

${ }^{18}$ Some Pacific Island Territories have higher HDI scores. For example Palau had a score of 0.861 in 1998. McIntyre, Pacific Environment Outlook, 16.

${ }^{19}$ New Zealand Agency for International Development (NZAID), Pacific Strategy 2007 - 2015, 1.

${ }^{20}$ Charles Perrings, "The economics of biological invasions," Land Use and Water Resources Research 1, no. 3 (2001): 6 .

21 J. A. McNeely et al., eds., A global strategy on invasive alien species (Gland, Switzerland, and Cambridge, UK: IUCN, 2001), viii.

22 This study underestimates the true cost of invasive species as it does not assign monetary value to species extinctions, losses in ecosystem services, or aesthetics.

D. Pimentel et al., "Economic and environmental threats of alien plant, animal, and microbe invasions," Agriculture, Ecosystems \& Environment 84, no. 1 (2001): 14.
} 
While there is a significant quantity of literature discussing invasive species management, in addition to that for aid and conservation; there is currently a lack of literature focussing on aid for invasive species assistance. This research attempts to bridge this gap by examining the role of four New Zealand government agencies who assist with invasive species management issues in the Pacific: the International Development Group of the Ministry of Foreign Affairs (IDG MFAT), the Biosecurity New Zealand division of the Ministry of Agriculture and Forestry (MAFBNZ), the Department of Conservation (DOC), and Landcare Research.

Chapter Two explains what invasive species are, how they are spread, and what the causes of their increasing transportation are. It then describes the economic, environmental, and social costs of invasive species, as well as some of the techniques used to manage their impacts.

Chapter Three examines the current invasive species management architecture in the Pacific. It studies the international context and examines regional development strategies to see how much priority is given to invasive species. Finally, the various state and intergovernmental agencies involved with invasive species management in the Pacific are investigated. Although NGOs and private foundations provide a large amount of the funding and implement a lot of invasive species work, they are not part of this research.

Chapter Four assesses the four New Zealand agencies that provide funding, build capacity, offer technical advice, and occasionally implement projects in the Pacific. It describes how they assist the Pacific, their motivations for doing so, and how much they collaborate with each other.

The final chapter examines some possible explanations as to why there is not a greater level of awareness and attention given to invasive species management in the Pacific. It also offers some suggestions for possible improvements in the future.

\subsection{Methods}

This project was granted ethics approval by the Human Ethics Committee, Victoria University of Wellington (RM\#18222) (Appendix A). Information sheets detailing the project aims and interview process were sent to potential participants from key agencies working on invasive species in the Pacific (Appendix B). Sample questions were also given to participants at this time (Appendix C). Signed consent forms were returned before an interview took place (Appendix D). 
A review of the literature pertaining to invasive species issues and their management was performed. This included literature relating to donor motivations for giving environmental aid. Regional and organisational strategies and annual reports were examined to determine if they included reference to invasive species.

Semi-structured interviews were conducted face-to-face and by telephone with representatives from key agencies working on invasive species in the Pacific. Correspondance via email took place with representatives from key agencies, where interviews were not possible (Appendix E).

Finally, the "Resilience in the Pacific: Addressing the Critical Issues" conference was attended to see first-hand how much attention was given to invasive species issues in the Pacific. This conference was held in Wellington and focussed on the key challenges facing the region. 


\section{What are invasive species?}

For thousands of years people have transported and traded species to new areas outside of their original ranges. However, this process has only occurred on a truly global scale over the last 500 years or so, and has accelerated significantly over the last 50 years with the rapid movement of goods and people in increasingly large quantities. ${ }^{23}$ The total number of alien species in a country can be quite large. For example, in the USA there are approximately 50,000 alien species, ${ }^{24}$ and in New Zealand there are about 27,000 ${ }^{25}$ introduced species compared to $80,000^{26}$ native animals, plants, and fungi. Many of these alien species have been relatively benign, and some have been very beneficial: Pimental et al. note that in the USA introduced species such as corn, wheat, rice, and other food crops; and cattle, poultry, and other livestock; provide more than $98 \%$ of the food system at a value of approximately USD $\$ 800$ billion per year. ${ }^{27}$

Nevertheless, while some alien species are very important and valuable, there are some that, once established in a habitat, ${ }^{28}$ can have dramatic negative impacts on economies, livelihoods, the environment, and social wellbeing. ${ }^{29}$ These particular species are known as invasive species and are usually, although not always, introduced unintentionally. ${ }^{30}$ Invasive

\footnotetext{
${ }^{23}$ Hulme describes three major phases of global species redistribution: beginning around 1500 AD with the European rediscovery of the Americas and the start of global exploration; during the Industrial Revolution with increased levels of trade and emigration and the construction of canals and railways; and over the last 50 years with large volumes of trade and the movement of people.

P. E Hulme, "Trade, transport and trouble: managing invasive species pathways in an era of globalization," Journal of Applied Ecology 46, no. 1 (2009): 10-11.

${ }^{24}$ D. Pimentel, R. Zuniga, and D. Morrison, "Update on the environmental and economic costs associated with alien-invasive species in the United States," Ecological Economics 52, no. 3 (2005): 273.

${ }^{25}$ New Zealand Biodiversity, "Pests and weeds," n.d., https://www.biodiversity.govt.nz/picture/biodiversity/state/pests.html.

${ }^{26}$ Department of Conservation (DOC), "What is biodiversity," n.d., http://www.doc.govt.nz/getting-involved/eventsand-awards/international-year-of-biodiversity/what-is-biodiversity/.

${ }^{27}$ Pimentel, Zuniga, and Morrison, "Update on the environmental and economic costs associated with alieninvasive species in the United States," 273.

${ }^{28}$ The risk of an introduced species surviving, establishing, and becoming invasive is typically very low, although it has been noted that this risk may be as high as $17 \%$ for some weedy species.

Perrings, "The economics of biological invasions," 4.

${ }^{29}$ Native species can also be invasive when outside of their natural range - Metrosideros excelsa's natural range is limited to the northern part of the North Island, New Zealand. However, it is now becoming widespread and hybridising with southern Metrosideros species.
}

CBD Executive Secretary, Invasive Alien Species, Case-studies and Country Comments on Invasive Alien Species, Subsidiary Body on Scientific, Technical and Technological Advice (Montreal: Convention on Biological Diversity, 2001), 15, http://www.issg.org/cii/Electronic references/pii/CBD_IAS case studies.pdf.

${ }^{30}$ An example of an intentional introduction is the Australian brushtail possum which was introduced in New Zealand in 1837 to establish a fur trade. Without their natural controlling factors such as natural predators, bush fires, and the low nutritional value of eucalyptus leaves, possums numbers in New Zealand are able to reach many 
species predate on, or are able to out-compete, native species or other beneficial species, which can lead to biodiversity declines and ultimately less resilient ecosystems. They occur in all major taxonomic groups, including viruses, fungi, algae, mosses, ferns, higher plants, invertebrates, fish, amphibians, reptiles, birds, and mammals, ${ }^{31,32}$ and occur in terrestrial, marine, and marine ecosystems. ${ }^{33}$ Also, some alien species that currently do not cause harm to the environment or human interests may do so if environment conditions change in the future, for example with climate change. ${ }^{34}$

\subsection{What makes them invasive?}

Invasive species are typically fast growing and have rapid reproduction, high dispersal ability, tolerance to a wide range of environmental conditions, and the ability to live off a wide range of food types. ${ }^{35}$ They tend to be good at colonising disturbed ground, such as when people convert habitats or when new ground is exposed due to landslides, erosion, or natural disasters. $^{36}$ Invasive species often arrive in a new habitat without the natural predators, competitors, diseases, and parasites that keep their numbers in check in their natural range. ${ }^{37}$ Some invasive species also use tactics that native species are less able to deal with - the leaf litter of the various species of Eucalyptus contain chemical compounds that prevent other species from growing. ${ }^{38}$

\footnotetext{
tens of millions. As well as damaging native forests and predating on native birds, the possum can also spread bovine tuberculosis which could greatly affect the dairy and deer industry.

Department of Conservation (DOC), "The threat of Possums," n.d., http://www.doc.govt.nz/conservation/threatsand-impacts/animal-pests/animal-pests-a-z/possums/the-threat/.

${ }^{31}$ McNeely et al., A global strategy on invasive alien species, 6.

${ }^{32}$ Most invasive species management programmes target mammals, invertebrates, and weeds. Although diseases and pathogens can cause the largest impacts, even this sub-section of invasive species can cause significant damage.

Alan Saunders, “Landcare Research,” interview by Simon Lovatt, January 25, 2011.

${ }^{33}$ CBD Executive Secretary, Pilot Assessments: The Ecological and Socio-economic Impact of Invasive Alien Species on Island Ecosystems, Subsidiary Body on Scientific, Technical and Technological Advice (Montreal: Convention on Biological Diversity, 2003), 27, http://www.issg.org/cii/Electronic references/pii/CBD_IAS island impacts.doc.

${ }^{34}$ One study found some species may take decades to become "invasive", which could mean that many more potentially destructive species may already be present in the Pacific than is currently realised.

Alister Doyle, "Invasive Species Lie in Wait, Strike After Decades," ABC News, December 20, 2010, http://abcnews.go.com/Technology/wireStory?id=12442736\&page=1.

${ }^{35}$ Praseeda Sanu and Jeyanth Newport, "Invasive alien species dispersal: the millennium biodiversity disaster," Disaster Prevention and Management 19, no. 3 (2010): 295.

${ }^{36}$ For example, in Niue invasive species became more prevalent in areas disturbed by Cyclone Heta in 2004. James Space et al., Report to the Government of Niue and the United Nations Development Programme: Invasive Plant Species on Niue following Cyclone Heta (United Nations Development Programme (UNDP), December 17, 2004), 3-4, http://www.sprep.org/att/IRC/eCOPIES/INVASIVE SPECIES/niue.pdf.

${ }^{37}$ CBD Executive Secretary, Invasive Alien Species, Case-studies and Country Comments on Invasive Alien Species, 14.

${ }^{38}$ McNeely et al., A global strategy on invasive alien species, 13.
} 


\subsection{How are invasive species spread?}

Invasive species may be spread to new regions both intentionally and unintentionally by a variety of different mechanisms - on land (cars, jeeps, trucks, buses, carts, trains); in air (airplanes and other airborne devices); and in water (ships, boats, canals), ${ }^{39}$ with ships and planes likely to be the most significant vector for islands. ${ }^{40}$ Many invasive species may be transported unintentionally on a wide variety of substrates; for example on ship hull fouling or in ballast water, ${ }^{41}$ in freight containers, in soil, in packaging material, in freight (especially food or wood products), and on machinery. Invasive species may also be intentionally released acclimatisation societies released plants and animals for food, recreational, or aesthetic reasons to recreate similar conditions to those of the colonists' origin, or to try to "improve" local biodiversity. ${ }^{42}$ More recently, in the 1990s, Australian rainbow lorikeets were deliberately released in New Zealand by breeders, and the species now competes with native birds for food and nesting sites, as well as potentially carrying avian diseases and impacting the commercial fruit growing industry. ${ }^{43}$

\subsection{What are the causes of invasive species?}

International trade and tourism are the major causes of the spread of invasive species, where rapid transport and repeat invasions help ensure the survival and establishment, as well as providing greater genetic diversity, for the introduced population. ${ }^{44}$ Indeed, several studies note a positive correlation between the level of trade, gross domestic product (GDP), and the number of invasive species in a country or region. ${ }^{45}$ It is worth noting that invasive species can spread within a country as well. ${ }^{46}$ New roads, plantations, irrigation systems, canals, tunnels, and even undersea cables can provide routes for species to spread. ${ }^{47}$ People can

\footnotetext{
39 Sanu and Newport, "Invasive alien species dispersal," 292.

${ }^{40}$ CBD Executive Secretary, Pilot Assessments: The Ecological and Socio-economic Impact of Invasive Alien Species on Island Ecosystems, 27.

${ }^{41}$ One study estimates that ballast water alone transports 10,000 species globally every day. See: Hulme, "Trade, transport and trouble," 13.

${ }^{42}$ Carl Walrond, "Acclimatisation - Improving upon nature -," Te Ara Encyclopedia of New Zealand, March 2009, http://www.teara.govt.nz/en/acclimatisation/1.

${ }^{43}$ Department of Conservation (DOC), "Rainbow lorikeet," n.d., http://www.doc.govt.nz/conservation/threats-andimpacts/animal-pests/animal-pests-a-z/rainbow-lorikeet/.

${ }^{44}$ L. A Meyerson and H. A Mooney, "Invasive alien species in an era of globalization," Frontiers in Ecology and the Environment 5, no. 4 (2007): 201.

${ }^{45}$ C. Perrings et al., "How to manage biological invasions under globalization," Trends in Ecology \& Evolution 20 , no. 5 (2005): 212.

P. Pyšek et al., "Disentangling the role of environmental and human pressures on biological invasions across Europe," Proceedings of the National Academy of Sciences 107, no. 27 (2010): 12157.

${ }^{46}$ D. R Paini et al., "Threat of invasive pests from within national borders," Nature Communications 1 , no. 115 (2010): 2.

47 Hulme, "Trade, transport and trouble," 15.
} 
also be responsible for transporting invasive species - in Fiji, despite an Emergency Biosecurity Declaration prohibiting the movement of animals or eggs, locals were transporting American iguanas around the islands as pets not realizing they were different from the native Fijian iguana. ${ }^{48}$

Major economic sectors can be sources of invasive species, ${ }^{49}$ especially in agriculture and horticulture where some plants are selected for their survival in the local climate and easy propagation. ${ }^{50}$ Invasive species can also escape from aquaculture and mariculture facilities; personal aquariums, pets, and ornamental plants; be released for fishing and hunting; or even be failed biocontrol attempts - the cane toad was introduced to Australia in an unsuccessful attempt to control the greyback cane beetle and has now become a serious invasive pest in its own right. ${ }^{51}$ Less obvious sources can be the military, ${ }^{52}$ and aid and disaster relief responses (both from the workers themselves and contaminated food supplies $^{53}$ ). The brown tree snake is thought to have been introduced to Guam on American military equipment after World War 2 , and has dramatically reduced native bird, mammal, and lizard populations. In addition, the snake eats poultry and pets, occasionally attacks people, and also cause power outages from climbing along power lines. The annual cost of this pest is estimated at about USD $\$ 12$ million per year. ${ }^{54}$

\footnotetext{
${ }^{48}$ Pacific Invasives Initiative (PII), The PII News, December 2010, 4, http://www.issg.org/cii/Electronic references/pii/PII_News/2010/the_pii_news_dec_2010.pdf.

American iguanas are herbivores and so they eat the vegetables and fruits that subsistence villages depend on. They are also possible vectors for pathogens and parasites that might infect the endangered Fijian iguanas. Finally, they pose a threat to human health as they have sharp claws and are known carriers of Salmonella. Ministry of Primary Industries, "Silent and sinister - is the American iguana here to stay?," December 2, 2010, http://www.agriculture.org.fj/index.cfm?si=main.resources\&cmd=forumview\&cbegin=0\&uid=aigcampaign\&cid=139 3.

${ }^{49}$ McNeely et al., A global strategy on invasive alien species, 12. IUCN/SSC Invasive Species Specialist Group (ISSG), IUCN guidelines for the prevention of biodiversity loss caused by alien invasive species, 8.

${ }^{50}$ Perrings et al., "How to manage biological invasions under globalization," 213.

${ }^{51}$ CBD Executive Secretary, Invasive Alien Species, Case-studies and Country Comments on Invasive Alien Species, 19.

52 The Australian Defense Force undertook a major exercise (300 staff operating 20 wash stations 18 hours every day for three months) to remove all potential alien species contamination from military equipment being returned to Australia from East Timor.

lbid., 16.

${ }^{53}$ Global Invasive Species Programme (GISP), Invasive Species and Poverty: Exploring the Links (Cape Town, South Africa: Global Invasive Species Programme (GISP), 2007), 10, http://www.gisp.org/publications/reports/invasivesandpoverty.pdf.

${ }^{54}$ Pimentel, Zuniga, and Morrison, "Update on the environmental and economic costs associated with alieninvasive species in the United States," 277.
} 


\subsection{Why are islands so vulnerable?}

Although islands are geographically isolated and thus potentially less susceptible to invasions by alien species, they are considered to be particularly vulnerable to the impacts of any invasive species that do manage to establish themselves for ecological and socioeconomic reasons. ${ }^{55}$ Half to two-thirds of all species extinctions have occurred on islands, ${ }^{56}$ and invasive species are the primary cause of this biodiversity loss. ${ }^{57}$ Indeed, the largest number of documented extinctions worldwide has occurred in Oceania, which also currently has more threatened species than any other region. ${ }^{58}$

The isolation of islands has encouraged the evolution of unique species, many of which are endemic and so are not found anywhere else in the world. These species may also have few defense mechanisms as they have evolved without predators - for instance many New Zealand birds are flightless and tend to be more odiferous than continental birds which makes it easier for introduced predators such as stoats and weasels to locate them. ${ }^{59}$ Islands generally have small land areas meaning that there tends to be fewer and smaller populations of species, and the species are generally less capable of moving elsewhere. ${ }^{60}$ Islands tend to have a limited range of ecosystems, and the ones they have are fragile. ${ }^{61}$ In particular, the islands in the Pacific are also prone to natural disasters such as cyclones, flooding, and landslides, ${ }^{62}$ in addition to earthquakes, tsunamis, and volcanoes for countries located on the Pacific Rim of Fire. Invasive species tend to have an advantage in recolonising these disturbed habitats.

As mentioned above, international trade is a major factor in the movement of invasive species, and island economies have a higher proportion of merchandise imports as a share of GDP than continents $(38 \%$ vs. $27 \%){ }^{63}$ Islands also have large volumes of migration. Mclntyre

\footnotetext{
${ }^{55}$ CBD Executive Secretary, Pilot Assessments: The Ecological and Socio-economic Impact of Invasive Alien Species on Island Ecosystems, 1.

${ }^{56}$ S. W Burgiel and A. A Muir, Invasive Species, Climate Change and Ecosystem-Based Adaptation: Addressing Multiple Drivers of Global Change (Washington, DC, USA, and Nairobi, Kenya: Global Invasive Species

Programme (GISP), September 2010), 4.

${ }^{57}$ Millennium Ecosystem Assessment, Ecosystems and Human Well-being, 16.

${ }^{58}$ Mclntyre, Pacific Environment Outlook, 44.

59 100\%Pure New Zealand, "Smelly NZ birds may need odour protection > New Zealand," September 24, 2010, http://www.newzealand.com/travel/media/press-releases/2010/9/nature_smelly-nz-birds-may-need-odourprotection_press-release.cfm.

${ }^{60}$ CBD Executive Secretary, Pilot Assessments: The Ecological and Socio-economic Impact of Invasive Alien Species on Island Ecosystems, 5.

61 There is often more than one species performing a given role in an ecosystem, but because islands tend to have less biodiversity there is less redundancy to maintain ecosystem functioning and services.

62 From 1990 to 1999 the Pacific led the entire world in rates of disaster-related mortality, percentage of population affected and disaster damage costs per capita gross national product (GNP).

McIntyre, Pacific Environment Outlook, 2.

${ }^{63}$ Hulme, "Trade, transport and trouble," 11.
} 
notes that there are approximately three million visitors to the Pacific each year; ${ }^{64}$ which could potentially introduce large numbers of alien species to the region. High rates of population growth can create pressure to clear natural ecosystems to provide extra land for agriculture or forestry either for domestic use or for export. Not only are these disturbed habitats more susceptible to colonisation by invasive species, but the resulting crops tend to have low levels of biodiversity which makes them vulnerable to introduced pests and diseases. ${ }^{65}$ Having a high dependence on marine resources may also encourage aquaculture or mariculture enterprises, which species can then escape from or can carry diseases that affect local varieties. ${ }^{66}$ Additionally, many islands have limited human, institutional, and financial capacity to manage invasive species; both in terms of skilled staff and adequate facilities, appropriate biosecurity legislation and emergency response plans, and the ability to pay for the above.

\subsection{What are the costs of invasive species?}

Invasive species can have rapid and wide-ranging impacts in their host countries. These impacts broadly fall into three categories: economic (lost productivity, effects on related industries, trade bans, and the cost of managing invasive species); environmental (lost biodiversity and resultant changes in ecosystem functioning); and social (health, nutrition, culture, and well-being from ecosystem services). Please note, that these categories are all interlinked and cannot really be separated, especially on islands, where people depend on healthy ecosystems for their livelihoods and well-being.

\subsubsection{Economic impacts}

Although the risk of invasive species establishing tends to be low, the economic costs can be very large. These costs include:

- the direct effects on economic sectors (e.g., agriculture, forestry, shipping);

- indirect costs to the economic sector, for example from trade bans and/or loss of markets, or damage to the tourism industry;

- effects on human health, resulting in lost productivity and medical costs; and

- the direct and indirect costs of prevention, eradication, or control (including delays to the movement of goods and passengers). ${ }^{67}$

\footnotetext{
${ }^{64}$ Mclntyre, Pacific Environment Outlook, 12.

${ }^{65} \mathrm{C}$. Perrings et al., "Biological invasion risks and the public good: an economic perspective," Conservation Ecology 6, no. 1 (2002): 3.

${ }^{66}$ CBD Executive Secretary, Invasive Alien Species, Case-studies and Country Comments on Invasive Alien Species, 16.

67 Ibid., 22.
} 
Just as economic activities can be a source of invasive species, invasive species also have major impacts on agriculture, fisheries, infrastructure, tourism, and human and animal health. For example, Mikania micrantha, is a fast-growing and fast-spreading weed also known as "Mile-a-minute", as it can grow up to $8 \mathrm{~cm}$ per day. It is capable of rapidly smothering large trees, causing significant losses in plantations, native forests, and home gardens. ${ }^{68}$ Miconia calvescens (also known as green cancer) was introduced to French Polynesia in 1937. It can grow up to $15 \mathrm{~m}$ tall with leaves up to $75 \mathrm{~cm}$ in length, which shade out other plants and prevent them from growing. Its shallow roots also promote landslides and erosion, and the weed is easily spread by birds, walking shoes, and construction equipment. ${ }^{69}$

\section{Fisheries}

The lionfish is a voracious predator native to the South Pacific, Indian Ocean, and the Red Sea. It was released from aquariums in Florida in the mid-1980s and has now become established throughout the Caribbean and the Atlantic Coast of the USA. ${ }^{70}$ Because of their venomous spikes lionfish have no natural predators in the region, and so high density populations can establish. Lionfish eat large quantities of reef fish, which negatively impacts commercial fisheries as well as overall reef health. ${ }^{71}$

\section{Infrastructure}

The Asian subterranean termite has recently been found in Fiji, where it has infested and damaged houses, trees, timber, as well as root crops. ${ }^{72}$ Similarly, the Formosan subterranean termite is the most economically damaging pest in Hawaii; the cost to prevent or control infestations and to repair the damage has been conservatively estimated at more than USD $\$ 60$ million a year. ${ }^{73}$

\section{Animal health}

Chilean needle grass is a plant pest that has been found in the Marlborough, Hawke's Bay, and recently Canterbury regions of New Zealand. It produces sharp, cork-screw shaped seed heads that can burrow into animal skin, damaging the hides and causing the meat to

\footnotetext{
${ }^{68}$ Asia-Pacific Forest Invasive Species Network (APFISN), "Invasives: Newsletter of the," February 2007, 3 , http://www.fs.fed.us/global/topic/invasives/feb2007.pdf.

${ }^{69}$ CBD Executive Secretary, Invasive Alien Species, Case-studies and Country Comments on Invasive Alien Species, 11.

${ }^{70}$ Burgiel and Muir, Invasive Species, Climate Change and Ecosystem-Based Adaptation, 16.

71 Jacqui Goddard, "Lionfish devastate Florida's native shoals," The Times, October 20, 2008, http://www.timesonline.co.uk/tol/news/environment/article4974396.ece.

72 SPC Land Resources Division, "SPC assists Fiji in efforts to manage the termite problem," August 5, 2010, http://www.spc.int/lrd/index.php?option=com_content\&view=article\&id=496:taropest\&catid=23\&ltemid=18.

${ }^{73}$ CBD Executive Secretary, Invasive Alien Species, Case-studies and Country Comments on Invasive Alien Species, 14.
} 
callus, which reduces the value of the carcasses. Animals can also become blind if the seeds penetrate their eyes. ${ }^{74}$

\section{Multiple Impacts}

Many invasive species can affect multiple economic sectors simultaneously. Rats spoil crops and destroy stored grains (agriculture), pollute food products and act as vectors for diseases such as leptospirosis (human health), and cause fires by gnawing on electrical wires (infrastructure). ${ }^{75}$ In addition, rats also prey on vertebrates like seabirds which can have impacts not only on tourism revenue, but also on entire ecosystems. Seabirds are a keystone species ${ }^{76}$ and they play a critical role in cycling nutrients from marine environments to terrestrial ecosystems in the form of droppings, spilt regurgitations, addled eggs, and corpses. $^{77}$ This provides food for invertebrates, who are in turn eaten by other species such as lizards.

From a socio-economic and ecological perspective, ants are probably the most harmful group of invasive insects on islands. ${ }^{78}$ Some species form high density supercolonies with thousands of mounds per hectare, and up to 2250 foraging ants per square metre. ${ }^{79}$ Ants feed on agricultural crops, their mounds impede crop harvesting vehicles and can damage the machinery itself, ${ }^{80}$ and swarms of ants can prevent harvesting of plantations and home gardens. ${ }^{81}$ Ants are responsible for stock losses (especially during birth), ${ }^{82}$ and some species cause blindness when they spray formic acid into animal eyes. Their stings are very painful and result in blistering of the skin (and occasionally life-threatening allergic reactions ${ }^{83}$ ), which not only affects local people but can also discourage tourists. Ants also prey on the native species such as birds that tourists come to see. They are attracted to electrical fields and

\footnotetext{
${ }^{74}$ Environment Canterbury, "Plant Pest: Chilean Needle Grass," n.d., http://www.ecan.govt.nz/publications/General/ChileanNeedleGrassFlyerA.pdf.

${ }^{75}$ Pimentel, Zuniga, and Morrison, "Update on the environmental and economic costs associated with alieninvasive species in the United States," 276.

${ }^{76}$ A keystone species is a species whose importance and impact on an ecosystem is far greater than would be expected given its biomass. Removing a keystone species can lead the ecosystem to collapse, similar to removing the keystone of an archway.

77 Department of Conservation (DOC), "Mana Island Scientific Reserve," n.d., http://www.doc.govt.nz/parks-andrecreation/places-to-visit/wellington-kapiti/kapiti/mana-island-scientific-reserve/features/conservation/.

${ }^{78}$ CBD Executive Secretary, Pilot Assessments: The Ecological and Socio-economic Impact of Invasive Alien Species on Island Ecosystems, 16.

${ }^{79}$ K. L. Abbott, "Supercolonies of the invasive yellow crazy ant, Anoplolepis gracilipes, on an oceanic island: forager activity patterns, density and biomass," Insectes Sociaux 52, no. 3 (2005): 266.

${ }^{80}$ Pacific Invasive Ant Group (PIAG), Pacific Ant Prevention Plan (Pacific Plant Protection Organisation and Regional Technical Meeting For Plant Protection, March 2004), 14, http://www.issg.org/database/species/reference_files/PAPP.pdf.

81 Saunders, "Landcare Research."

82 Pacific Invasive Ant Group (PIAG), Pacific Ant Prevention Plan, 14.

${ }^{83}$ S. Moloney and C. Vanderwoude, "Red Imported Fire Ants: A threat to eastern Australia's wildlife?," Ecological Management \& Restoration 3, no. 3 (2002): 167.
} 
can cause expensive damage to electrical and irrigation equipment. Ants can also dramatically alter ecosystems by direct predation, habitat alteration, or competition for food. For example, yellow ants kill land crabs (another keystone species) which are the dominant consumers of rainforest detritus. Without the crabs large leaf litters accumulate, causing rapid changes in the entire ecosystem because nutrients are no longer cycling through the soil as quickly. Ants promote the growth of sooty mould on trees which can decrease photosynthesis rates and reduce tree survival. They also reduce numbers of fruit-eating birds which affects pollination and seed dispersal which is crucial for maintaining the structure and diversity of some ecosystems. ${ }^{84}$

\section{The cost of invasive species}

In 2001, Pimental et al. calculated that the economic cost of invasive species worldwide was USD $\$ 1.4$ trillion annually, which equates to $5 \%$ of the global economy at that time. ${ }^{85} \mathrm{~A}$ more recent assessment using the same parameters estimated the cost of damages and managing invasive species in the USA alone was USD\$120 billion per year. This included USD \$27 billion for agriculture weeds, $\$ 21.5$ billion for plant pathogens, $\$ 19$ billion for rats, $\$ 17$ billion for cats, $\$ 14.5$ billion for arthropod agriculture pests, $\$ 14$ billion for livestock diseases, and $\$ 7.5$ billion for human diseases. ${ }^{86}$ Both of these figures are conservative estimates that did not assign any monetary value to species extinctions, or losses in biodiversity, ecosystem services, and aesthetics - if these had been included the total values would have been several times higher.

In Samoa, the taro industry was decimated in 1993 by the taro leaf blight fungus (Phytophthora colocasiae). Taro was a staple food crop and Samoa's most important export, as well as being culturally important. ${ }^{87}$ The disease is estimated to have cost the country USD $\$ 40$ million to replace domestic consumption, lost exports, and the cost of measures to control the disease. ${ }^{88}$ It has taken almost 20 years for the industry to recover. ${ }^{89}$

\footnotetext{
${ }^{84}$ CBD Executive Secretary, Pilot Assessments: The Ecological and Socio-economic Impact of Invasive Alien Species on Island Ecosystems, 12.

85 This included damage from plants, mammals, birds, reptiles, amphibians, fish, arthropods, molluscs, livestock diseases, and human diseases including HIV Aids and influenza; as well as the cost of managing these species. Pimentel et al., "Economic and environmental threats of alien plant, animal, and microbe invasions," 14.

${ }^{86}$ Pimentel, Zuniga, and Morrison, "Update on the environmental and economic costs associated with alieninvasive species in the United States," 274.

${ }^{87}$ Mary Anne Plummer, "Farming Systems Project: Samoa," AusAID, n.d., http://www.ausaid.gov.au/publications/focus/focuspdfs/997/99729.pdf.

${ }^{88}$ To put this in perspective, this is higher than the impact of three cyclones.

Secretariat of the Pacific Regional Environment Programme (SPREP), "Factsheet: Invasive Species," n.d., http://www.sprep.org/factsheets/invasives/index.htm.

${ }^{89}$ Radio New Zealand International, "Samoa resumes taro export after blight debacle," July 7, 2010, http://www.rnzi.com/pages/news.php?op=read\&id=54570.
} 
New Zealand has approximately 27,000 alien species, ${ }^{90} 222$ of which are considered to be invasive. $^{91}$ The annual loss of productivity and cost of managing invasive species was calculated at $\sim 2 \%$ of GDP, or NZD $\$ 3.3$ billion. $^{92}$ This value was calculated from the loss of productivity, the impacts on upstream and downstream industries, and the cost of prevention and management of introduced pests. Some of the most economically important invasive species are clover root weevil (\$312 million), Argentine Stem Weevil (\$160 million), possums (\$52 million), rabbits (\$50 million), and gorse (\$31 million). ${ }^{93}$ The parasitic Varroa mite was detected in New Zealand in 2000, and it has impacts not only on the beekeeping industry but is also potentially damaging for crop pollination and pollination of pasture legumes. It is estimated that one third of the food we eat relies on honey bees for pollination, ${ }^{94}$ so the economic cost could be far greater than the $\$ 15$ million calculated. Another recent invasive pest is the bacteria Pseudomonas syringae pv. actinidiae (PSA) which infects kiwifruit vines. This could affect the country's $\$ 1.5$ billion export industry, particularly as Australia and the USA have banned imports of New Zealand kiwifruit plants (although currently they still accept the fruit). ${ }^{95}$

\subsubsection{Environmental impacts}

While most economic impact studies have focused on alien species in the primary production sectors, invasive species can also have large environmental and biodiversity impacts. ${ }^{96}$ They are the primary cause of extinctions on islands, ${ }^{97}$ and one of the leading causes of biodiversity loss worldwide. As McNeely et al. note, invasive species often alter ecosystems drastically; upsetting species composition, changing soil chemistry, hydrology, and fire frequency. ${ }^{98}$

Invasive species can impact all levels of biodiversity - genes (hybridisation); species (predation, competition, parasitism), habitats (fragmentation, alteration, destruction), and

\footnotetext{
${ }^{90}$ New Zealand Biodiversity, "Pests and weeds."

91 M. A McGeoch et al., "Global indicators of biological invasion: species numbers, biodiversity impact and policy responses," Diversity and Distributions 16, no. 1 (2010): 16.

92 Nick Giera and Brian Bell, Economic Costs of Pests to New Zealand (Ministry of Agriculture and Forestry, September 2009), 3, http://www.biosecurity.govt.nz/files/pests/surv-mgmt/economic-costs-of-pests-to-newzealand.pdf.

93 Ibid., 39.

${ }^{94}$ MAF Biosecurity New Zealand, "Varroa Mite," June 30, 2009, http://www.biosecurity.govt.nz/pests/varroa.

953 News, "Imports of NZ kiwifruit cuttings banned," November 10, 2010, http://www.3news.co.nz/Imports-of-NZkiwifruit-cuttings-banned/tabid/423/articleID/185663/Default.aspx.

${ }^{96}$ CBD Executive Secretary, Invasive Alien Species, Case-studies and Country Comments on Invasive Alien Species, 22.

${ }_{97}$ Millennium Ecosystem Assessment, Ecosystems and Human Well-being, 16.

${ }^{98}$ McNeely et al., A global strategy on invasive alien species, 21.
} 
ecosystems (resource cycling and renewal, demand for resources, disturbance regimes). ${ }^{99}$ The impacts of invasive species can be direct or indirect, be cumulative over time, and can be long-term or even irreversible. They can also have cascading effects throughout an ecosystem. For example, in New Zealand the introduced brown trout predates on the native galaxiid (whitebait) fish as well as invertebrates. This increases the amount of algae in a stream (due to less invertebrate grazing), which alters nutrient flows throughout the food chain. $^{100}$

In Hawaii, introduced mangroves have altered coastline hydrodynamics and nearshore sedimentation, led to habitat loss for wetland birds, and provided a refuge for shorebird predators such as rats and mongoose, as well as the non-native mangrove crab. ${ }^{101}$

European cheatgrass (Bromus tectorum) has changed the shrub-steppe habitat of the Great Basin in Idaho and Utah, USA, by altering the fire regime, as the dead litter accumulates as fuel. Previously, fires occurred every 60-110 years, allowing shrubs to become well established. Because of the cheatgrass, fires now occur every 3-5 years and shrubs and other vegetation is diminished, leaving monocultures of cheatgrass on 5 million hectares in Idaho and Utah. Animals dependent on the shrubs and other original vegetation have been reduced or eliminated. ${ }^{102}$

An example of indirect effects can be seen by observing how invasive plants affect birds. They may replace native vegetation needed for food, shelter, or nesting. ${ }^{103}$ The fruit may be of lesser nutritional value to birds, or be unpalatable or even toxic to insects which reduces the availability of food to birds. ${ }^{104}$ Trees spreading on treeless islands such as the highlands of Santa Cruz Island, Galapagos, can also reduce the area available for ground nesting birds. $^{105}$

As this next example demonstrates, invasive species rarely impact on only one aspect of the economy, environment, or society. Water hyacinth (Eichornia crassipes) is a free-floating and

\footnotetext{
${ }^{99}$ CBD Executive Secretary, Pilot Assessments: The Ecological and Socio-economic Impact of Invasive Alien Species on Island Ecosystems, 9.

${ }^{100}$ C.R. Townsend and K.S. Simon, "Consequences of Brown Trout Invasion for Stream Ecosystems," Biological Invasions in New Zealand 186 (2006): 218.

${ }^{101}$ CBD Executive Secretary, Pilot Assessments: The Ecological and Socio-economic Impact of Invasive Alien Species on Island Ecosystems, 11.

102 Pimentel, Zuniga, and Morrison, "Update on the environmental and economic costs associated with alieninvasive species in the United States," 275.

103 Schmidt and Whelan found increased predation of birds that built their nests in the shorter, non-spiky invasive plants than in native shrubs.

K. A Schmidt and C. J Whelan, "Effects of exotic Lonicera and Rhamnus on songbird nest predation," Conservation Biology 13, no. 6 (1999): 1502.

${ }^{104}$ Carey Minteer, "I am a Bird Watcher. Why should I care about invasive species?," February 24, 2010, http://www.invasive.org/101/BirdWatcher.html.

${ }^{105}$ McNeely et al., A global strategy on invasive alien species, 10.
} 
fast growing freshwater plant native to Brazil. From the 1950s to the 1970s it was spread through mass campaigns in China for use as an ornamental plant, to provide livestock food, and to control pollution as it absorbs heavy metals. ${ }^{106}$ However, it is now regarded as the world's worst water weed and is among the 100 most troublesome invasive alien species globally. ${ }^{107}$ Water hyacinth is currently found throughout the Pacific, where it has huge environmental and social impacts.

\section{Environmental impacts of water hyacinth}

Water hyacinth forms dense mats of interlocking plants that choke slow-moving rivers and cover lakes, affecting water flow. It blocks the sunlight required for photosynthesis from entering the water column, which affects the growth and survival of the phytoplankton that form a vital part of freshwater food chains. It causes anaerobic conditions ${ }^{108}$ that reduce levels of fish and other species; and it absorbs large amounts of nitrogen, phosphorous, and other nutrients, denying them to other species. Water hyacinth also has rates of evapotranspiration ${ }^{109}$ three times higher than normal evaporation in open water. ${ }^{110}$ This can be a serious issue for irrigation or livestock watering ponds in dry areas.

\section{Social Impacts of water hyacinth}

Water hyacinth can greatly impede water transportation by canoes, dinghies, and larger vessels. This can obstruct access to communication, schools, health centres, government services, food gardens, fishing grounds, and local markets for the sale of crops. ${ }^{111}$ Loss of fishing habitats reduces protein intake for subsistence fisherpeople, and the weed increases the effort required to catch each fish. ${ }^{112}$ The weed can also impact human health by providing a breeding ground for mosquitoes and a species of freshwater snail known to host a parasitic flatworm that causes schistosomiasis. Large build-ups of water hyacinth can also damage infrastructure such as fence lines, low bridges, and its growth in dams, irrigation canals, and floodwater drainage systems in urban areas can result in serious and costly damage to these structures. ${ }^{113}$

\footnotetext{
106 J. McNeely, "Invasive species: a costly catastrophe for native biodiversity," Land Use and Water Resources Research 1, no. 2 (2001): 6.

107 S Lowe et al., 100 of the World's Worse Invasive Alien Species: A selection from the Global Invasive Species Database (Auckland, New Zealand: The Invasive Species Specialist Group (ISSG), 2004), 6 , http://www.issg.org/pdf/publications/worst_100/english_100_worst.pdf.

${ }^{108}$ Due to lower rates of photosynthesis and less physical mixing by the wind.

${ }^{109}$ Water loss to the air.

${ }^{110}$ Burgiel and Muir, Invasive Species, Climate Change and Ecosystem-Based Adaptation, 19.

${ }^{111}$ Secretariat of the Pacific Community (SPC), "Welcome to the Plant Protection Service Homepage," May 12, 2008, http://www.spc.int/pps/.

112 Sanu and Newport, "Invasive alien species dispersal," 293.

113 Secretariat of the Pacific Community (SPC), "Welcome to the Plant Protection Service Homepage."
} 


\subsubsection{Social impacts}

The social impacts of invasive species are especially important when the ecological impacts influence the ability of the ecosystems to provide goods and services which all people rely on. ${ }^{114}$ Subsistence farmers, fishers, and foresters who derive their livelihoods from nature are the most vulnerable to the effects of invasive species, although invasive species do affect everyone. In addition to loss of ecosystem services and the health and nutrition benefits they provide, invasive species can also directly affect food security, human health, cultures and traditions, and recreation and aesthetics.

Everyone in the world depends completely on Earth's ecosystems, ${ }^{115}$ and the goods and services they provide are essential to human well-being and survival. The Millennium Ecosystem Assessment, a four year study involving more than 1,300 scientists worldwide, defined four categories of ecosystem services: ${ }^{116}$

- provisioning - resources such as food, fibre, water, building material, medicine, and fuel;

- regulating - climate, floods, diseases, water and air purification;

- supporting - nutrient cycles, crop pollination, seed dispersal, soil formation, photosynthesis; and

- cultural - recreational, spiritual, educational, and aesthetic benefits.

All of these services are underpinned by biodiversity. Thus, biodiversity helps maintain ecosystem resilience, which is a measure of the ability of a system to maintain its integrity or health in the face of stresses or shocks. ${ }^{117}$ Any changes to or loss of biodiversity, for example due to invasive species, may potentially impact the ability of ecosystems to continue to provide these goods and services. ${ }^{118}$

Three quarters of the world's population directly depend on ecosystem services for their daily welfare, ${ }^{119}$ and as The Economics of Ecosystems and Biodiversity (TEEB) study notes, loss of biodiversity and ecosystems is inextricably intertwined with poverty. Subsistence livelihoods, particularly those relating to farming, animal husbandry, fishing, and forestry (i.e. most of the world's poor), are the most immediate beneficiaries of healthy ecosystems and their services. Livelihood flows from nature comprise more than half their welfare, which they

\footnotetext{
${ }^{114}$ CBD Executive Secretary, Pilot Assessments: The Ecological and Socio-economic Impact of Invasive Alien Species on Island Ecosystems, 15.

${ }^{115}$ Millennium Ecosystem Assessment, Ecosystems and Human Well-being, 1.

116 Ibid., v.

117 Perrings, "The economics of biological invasions," 5.

${ }^{118}$ CBD Secretariat, Global Biodiversity Outlook 3 (Montreal: Convention on Biological Diversity, 2010), 9, http://www.cbd.int/doc/publications/gbo/gbo3-final-en.pdf.

${ }^{119}$ United Nations, "Preserving Biodiversity Vital For Economic Growth," February 12, 2010, http://www.scoop.co.nz/stories/WO1002/S00300.htm.
} 
would find impossible to replace. ${ }^{120}$ This is true for the Pacific, where there is a high cultural and economic dependence on marine and terrestrial resources for daily needs such as food, water, shelter, and medicine. ${ }^{121}$

\section{Food security impacts}

In many countries in Africa, where an estimated 200 million people are chronically undernourished, ${ }^{122}$ nearly half of all crops are lost to invasive species. The parasitic plant Striga hermonthica causes annual losses in maize of USD \$7 billion, which adversely affects 300 million Africans. The maize weevil (Sitophilus zeamais), a common pest in most African countries, can destroy up to $40 \%$ of stored crops. Similarly, the larger grain borer (Prostephanus truncatus) can destroy $70 \%$ of dried stores, resulting in crop losses of up to USD $\$ 800$ million in West Africa alone. ${ }^{123}$ These and other invasive species have been estimated to cause losses in yield of eight of Africa's principal crops amounting to approximately USD $\$ 12.8$ billion per annum. ${ }^{124}$

\section{Human health impacts}

Several examples of the health impacts of invasive species have already mentioned, such as bites from the slightly venomous brown tree snake, stings from certain ant species, ${ }^{125}$ diseases carried by rats and freshwater snails, and freshwater weeds providing habitats for mosquitoes. A further example is the coqui frog which was accidentally introduced to Hawaii from Puerto Rico in 1988. In addition to posing substantial risks to the native Hawaiian biota, it has a call that is loud enough $\left(70-100\right.$ decibels $\left.^{126}\right)$ to potentially cause hearing loss with sustained exposure. ${ }^{127}$

\section{Cultural impacts}

Invasive species can cause the loss or replacement of culturally important native species, for example through predation by rats, browsing by goats, or habitat loss due to weeds. This can result in the loss of traditional knowledge (and changed practices) of food and medicine. The crown-of-thorns starfish has caused massive coral dieback, and hence the loss of viable

\footnotetext{
120 The Economics of Ecosystems and Biodiversity (TEEB), The Economics of Ecosystems and Biodiversity: An Interim Report (Brussels, Belgium: European Communities, 2008), 5, http://www.unep.ch/etb/publications/TEEB/TEEB_interim_report.pdf.

${ }^{121}$ McIntyre, Pacific Environment Outlook, 43.

122 Global Invasive Species Programme (GISP), Invasive Species and Poverty: Exploring the Links, 12.

${ }^{123}$ Burgiel and Muir, Invasive Species, Climate Change and Ecosystem-Based Adaptation, 20.

124 Global Invasive Species Programme (GISP), Invasive Species and Poverty: Exploring the Links, 10.

${ }^{125}$ For example, the red imported fire ant, the yellow crazy ant, and the little fire ant.

${ }^{126}$ See http://www.hear.org/alienspeciesinhawaii/species/frogs/index.html for audio examples.

127 The frog has also greatly reduced the property value of houses near the infestations.

Meyerson and Mooney, "Invasive alien species in an era of globalization," 203.
} 
habitat for hundreds of reef species, culturally damaging islander communities. ${ }^{128}$ Invasive plants and weeds can also cause damage to areas of cultural importance - for example in French Polynesia Miconia has invaded cultural sites, causing stone walls to rupture. ${ }^{129}$

Invasive ants can also severely disrupt social practises and routines. In Tokelau, the yellow crazy ant (which sprays formic acid that can burn the skin and cause severe eye irritations) is often found in houses, where they crawl over food, babies, and sleeping people. The Tokelauan (and indeed much of the Pacific) lifestyle is centred on sitting, eating, sleeping, weaving, and conducting other activities on the ground, and these ants severely interfere, and may potentially even threaten, this way of life. ${ }^{130}$ The little fire ant has drastically altered the 4000-year old practise of gardening of the Kanak people in the Mount Panié region of New Caledonia. The ants bite so badly that people now only garden at night (when the ants are less active), and they garden naked because the ants get into clothes and continue to bite for hours afterwards. The women no longer take their children to the family gardens, so gardening knowledge and thus the Kanak gardening culture may not be passed onto the next generation. ${ }^{131}$ The little fire ant also affects other countries in the Pacific. Many Solomon Islanders report that their dogs have been gradually blinded by the ants' venom, and hunting of wild pigs in French Polynesia has been adversely affected as hunting dogs are no longer able to hunt effectively due to vision impairment caused by the ants. ${ }^{132}$

However, invasive species do not always have negative cultural effects over the long term. ${ }^{133}$ Pfeiffer and Voeks note that many invasive plants that have been present in a country for more than 100 years have become "culturally enriching" through their incorporation into local cuisines, pharmacopoeias, and rituals. For example, in the USA invasive species have culturally symbolic statuses as state flowers or state birds. ${ }^{134}$

\footnotetext{
${ }^{128}$ Marine resources are used for food, medicine cultural and religious customs. The sharing of these resources among family and neighbors during gatherings (e.g., birthdays, weddings, funerals) reinforces important cultural and social relationships.

M. P. Crosby, G. Brighouse, and M. Pichon, "Priorities and strategies for addressing natural and anthropogenic threats to coral reefs in Pacific Island Nations," Ocean \& Coastal Management 45, no. 2 (2002): 123.

${ }^{129}$ CBD Executive Secretary, Pilot Assessments: The Ecological and Socio-economic Impact of Invasive Alien Species on Island Ecosystems, 14.

${ }^{130}$ Pacific Invasives Initiative (PII), "Tokelau: Nukunonu and Fakaofo Atolls -

Yellow crazy ant (Anoplolepis gracilipes)," July 6, 2009, http://www.issg.org/cii/PII/demo/tokelauAnt.html.

131 Saunders, "Landcare Research."

132 Pacific Invasive Ant Group (PIAG), Pacific Ant Prevention Plan, 19.

133 These species will still have had negative environmental and economic effects.

134 J. M Pfeiffer and R. A Voeks, "Biological invasions and biocultural diversity: linking ecological and cultural systems," Environmental Conservation 35, no. 04 (2008): 288.
} 


\section{Recreational and aesthetical impacts}

Didymosphenia geminate, commonly known as didymo or "rock snot", is an invasive algae of freshwater streams, rivers, and lakes first reported in New Zealand in $2004 .^{135}$ It forms large mats on the bottom of waterways that smothers rocks, plants, and other materials. As such it can interfere with recreational activities such as fishing or swimming, and decrease aesthetic appeal. It can cause eye irritations to swimmers, and although water containing didymo is safe to drink it may require treatment for an unpleasant odour and taste. In terms of economic impacts it can reduce tourist expenditures on freshwater activities, impact commercial eel fisheries, and clog water intake screens for hydroelectricity as well as municipal and agricultural water at an estimated cost of NZD \$24 million annually. ${ }^{136}$

\section{Conflict Species}

Some invasive species that are culturally, spiritually, or economically important can be desired despite their negative ecological impacts. These are known as conflict species. The Polynesian rat, also known as kiore, is regarded as taonga ${ }^{137}$ by Māori. However, rats also prey on birds, lizards, and invertebrates, as well as competing with native birds for food sources such as flowers, fruits, and seeds. ${ }^{138}$ In New Caledonia, rusa deer are highly valued as a food source and for recreational hunting purposes, but they can cause severe damage to native forests through browsing and trampling. ${ }^{139}$ Similarly, wild pigs are valued for hunting and food, although they damage crops and native vegetation, in addition to carrying diseases. ${ }^{140}$ The Nile Perch, introduced into Lake Victoria, Africa in the 1950s, has caused the extinction of over 200 native fish species and has greatly changed the food web of the lake. However it is known by the local people as Mkombosli, "the Saviour", as it is a significant source of food as well as the basis of a large export industry and a growing sport angler fishing industry. ${ }^{141}$ In New Zealand, the recreational salmonid industry, which includes brown trout, is worth NZD $\$ 800$ million annually. However, the full costs in terms of loss of

\footnotetext{
${ }^{135}$ MAF Biosecurity New Zealand, "Didymosphenia geminata Economic Impact Report-March 2006," April 30, 2008, http://www.biosecurity.govt.nz/pests-diseases/plants/didymo/economic-impact.htm.

${ }^{136}$ Giera and Bell, Economic Costs of Pests to New Zealand, 40.

${ }^{137}$ A treasured thing.

${ }^{138}$ Department of Conservation (DOC), "Rats," n.d., http://www.doc.govt.nz/conservation/threats-andimpacts/animal-pests/animal-pests-a-z/rats/.

${ }^{139}$ Pacific Invasives Initiative (PII), The PII News, 3.

${ }^{140}$ Lowe et al., 100 of the World's Worse Invasive Alien Species: A selection from the Global Invasive Species Database, 8.

${ }^{141}$ Global Invasive Species Programme (GISP), "GISP Phase I: Human Dimensions of Invasive Species," 2008, http://www.gisp.org/about/phase1/human.asp.
} 
native species and changes in ecosystem functioning, which potentially have wide-ranging impacts, is currently not known. ${ }^{142}$

Conflict species need to be managed carefully, with extensive stakeholder engagement and explanations of the full economic, environmental, and social costs and benefits.

\subsection{Climate change and invasive species}

Climate change is caused by anthropogenic emissions of carbon dioxide and other greenhouse gases, and it is expected to have large economic, ecological, and social impacts in the Pacific. It will affect water security, coastlines, food security, health, biodiversity based resources, as well as having social dimensions. ${ }^{143}$ Some of the impacts that can be expected include: losses of coastal infrastructure and land, more intense cyclones and droughts, failure of subsistence crops and coastal fisheries, losses of coral reefs and mangroves due to rises in temperature, and the spread of certain diseases such as mosquito-borne malaria. ${ }^{144}$ As the President of Kiribati said in his speech at the 2009 Copenhagen United Nations Climate Change Conference "climate change is overarching and it is a matter of national security". ${ }^{145}$

Individually, climate change and invasive species present two of the greatest threats to biodiversity and the provision of valuable ecosystem services. ${ }^{146}$ Worldwide costs of invasive species are estimated at about $5 \%$ of global GDP, ${ }^{147}$ and economic projections of global climate change-induced losses may range from 5-20\% of GDP. ${ }^{148}$ However, climate change and invasive species factors can also interact with each other, which will make the overall impacts more complex, more likely to occur, and more costly than for each of the drivers separately. Burgiel and Muir note that climate change will facilitate the introduction, establishment, and/or spread of invasive species; and that invasive species can reduce the

\footnotetext{
142 Townsend and Simon, "Consequences of Brown Trout Invasion for Stream Ecosystems," 223.

143 David Sheppard, "Building Resilience to Climate Change in the Pacific" (presented at the Resilience in the Pacific: Addressing the Critical Issues, Wellington, New Zealand, February 17, 2011), 40, http://ips.ac.nz/events/downloads/2011/Pacific Resilience presentations/Session 6 david sheppard.pdf.

144 Secretariat of the Pacific Regional Environment Programme (SPREP), "Factsheet: Pacific Climate Change," n.d., http://www.sprep.org/factsheets/climate/index.htm.

145 David Sheppard, "Pacific Biodiversity National Reports," April 4, 2010, http://www.sprep.org/article/news_detail.asp?id=758.

${ }^{146}$ Burgiel and Muir, Invasive Species, Climate Change and Ecosystem-Based Adaptation, 4.

${ }^{147}$ Pimentel et al., "Economic and environmental threats of alien plant, animal, and microbe invasions," 14.

${ }^{148}$ This calculation is based on the potential costs over the next 200 years of a business-as-usual (no mitigation or attempts to reduce emissions) scenario.

N. Stern, The Economics of Climate Change: the Stern Review (Executive Summary) (London, UK: HM Treasury, 2006), 10, http://siteresources.worldbank.org/INTINDONESIA/Resources/226271-1170911056314/34281091174614780539/SternReviewEng.pdf.
} 
ability of ecosystems to sequester greenhouse gasses and increase the impact of climate change-related events such as flooding and storm surges. ${ }^{149}$

\subsubsection{How climate change affects invasive species}

Climate change is anticipated to have significant implications for both native and non-native species. A shift in variables such as temperature or water availability may cause stress to species, particularly if this is outside their tolerance range. As invasive species are generally viewed as having a broader range of tolerances, this will give them a direct competitive advantage against native species as well as increase the types of suitable habitats to spread to. ${ }^{150}$ If native species are unable to migrate, climatically-induced stress might reduce their ability to resist invaders, and they might also become more prone to insect or pathogen damage. ${ }^{151}$ Changing climates can also make host environments more suitable to invasive species - there is already a detectable influence on terrestrial and marine pathogens, such as coral diseases and oyster pathogens, ${ }^{152}$ and with warming ocean temperatures other invasive species will potentially be able to extend their ranges towards the poles. ${ }^{153}$ New Zealand winters are much milder than in Europe which, in addition to the lack of natural predators, allows introduced wasp populations to reach some of the highest densities in the world. ${ }^{154}$ Rising temperatures may allow new invasive species to survive in New Zealand, and ones already present to extend their ranges further south. Alien species that are already present but currently do not cause harm to the environment or human interests may do so if environment conditions change in the future. ${ }^{155}$

Climate change will also increase the frequency and severity of extreme weather events such as flooding and cyclones. These in turn can facilitate the movement of invasive species at a regional and global scale. ${ }^{156}$ These events will also disturb ecosystems or make them more vulnerable to invasions. For example, droughts may leave gaps in vegetation, while erosion and landslides can create open spaces that invasive species, being generally faster growing than native species, are able to colonise. ${ }^{157}$ Relief efforts responding to such natural

\footnotetext{
${ }^{149}$ Burgiel and Muir, Invasive Species, Climate Change and Ecosystem-Based Adaptation, 5.

150 lbid., 10.

${ }^{151}$ McNeely et al., A global strategy on invasive alien species, 10.

152 International Fund for Agricultural Development (IFAD), Climate Change Impacts - Pacific Islands (International Fund for Agricultural Development, April 2009), 2, http://www.ifad.org/events/apr09/impact/islands.pdf.

${ }^{153}$ Burgiel and Muir, Invasive Species, Climate Change and Ecosystem-Based Adaptation, 17-18.

${ }^{154}$ MAF Biosecurity New Zealand, "Common wasp," October 22, 2008, http://www.biosecurity.govt.nz/pests/common-wasp.

${ }^{155}$ Doyle, "Invasive Species Lie in Wait, Strike After Decades."

${ }^{156}$ Burgiel and Muir, Invasive Species, Climate Change and Ecosystem-Based Adaptation, 7.

${ }^{157}$ McNeely et al., A global strategy on invasive alien species, 10.
} 
disasters have the potential to unintentionally introduce invasive species through foodstuffs containing non-native seeds or on construction, fire fighting, military, or other vehicles. ${ }^{158}$ Social responses to mitigate climate change may also promote the establishment of invasive species - building wind farms may disturb intact ecosystems, and $75 \%$ of almost 40 potential biofuel crops had a record of being invasive in some parts of the world. ${ }^{159}$

\subsubsection{How invasive species affect climate change}

Invasive species can affect climate change by compromising the ability of intact ecosystems to sequester carbon. For example, the North American mountain pine beetle has increased tree mortality, thereby reducing the amount of carbon dioxide that can be stored. Similarly invasive grasses, and the resultant changes in fire regimes, can displace native forest which also affects sequestration. ${ }^{160}$ Some invasive species can actually increase carbon sequestration, such as the Chinese tallow tree which has occupied wetland prairies and marshes in some southern states of the USA. However, this has had negative impacts on the rare plants and animals that used to live there, as well as caused the loss of productive grasslands. ${ }^{161}$

Invasive species can also increase the impacts of climate change. Healthy ecosystems such as floodplain forests and coastal mangroves provide storm protection and act as safety barriers against natural hazards such as floods, hurricanes, and tsunamis. ${ }^{162}$ Wetlands and estuaries can help protect against flooding, and dunes can help delay seawater from inundating coastal areas as well as supplying sand to replenish eroded areas. ${ }^{163}$ Hence, as one of the leading causes of biodiversity loss, invasive species reduce the ability of these ecosystems to resist climate change-related events. For example, nutria (a type of aquatic rodent) have converted large areas of marshland into open water, greatly increasing the vulnerability of inland areas to storm surges and erosion. ${ }^{164}$

\footnotetext{
${ }^{158}$ Burgiel and Muir, Invasive Species, Climate Change and Ecosystem-Based Adaptation, 10.

159 These crops tend to be fast-growing, tolerant of dry conditions or poor soils, and resistant to (or having few) pests.

Global Invasive Species Programme (GISP), Biofuel Crops and the use of Non-native Species: Mitigating the Risks of Invasion (Nairobi, Kenya: Global Invasive Species Programme (GISP), May 2008), 4-7, http://www.sprep.org/att/IRC/eCOPIES/Global/155.pdf.

${ }^{160}$ Burgiel and Muir, Invasive Species, Climate Change and Ecosystem-Based Adaptation, 8-9.

161 USDA Forest Service - Southern Research Station, "Invasive tallowtree spreading rapidly across Gulf coast," October 6, 2010, http://www.sciencedaily.com/releases/2010/06/100608135038.htm.

${ }^{162}$ World Bank, Convenient Solutions to an Inconvenient Truth: Ecosystem-based Approaches to Climate Change (Washington D.C.: World Bank, June 2009), 10, http://siteresources.worldbank.org/ENVIRONMENT/Resources/ESW_EcosystemBasedApp.pdf.

163 "Helping Islands Adapt - Concept Paper," April 2010, 2, http://www.conference.co.nz/files/docs/info doc 1 docdm-552471 concept paper v10 high res.pdf.

${ }^{164}$ Burgiel and Muir, Invasive Species, Climate Change and Ecosystem-Based Adaptation, 13-14.
} 


\subsection{Management of invasive species}

Management of invasive species covers the entire spectrum from prevention (biosecurity) to sustained control (suppression or containment) and eradication. Management is an intensive, slow, and difficult process, however given the potentially large costs and impacts of invasive species it should be seen as an investment rather than a burden. For example, the six year programme to eradicate the red imported fire ant from Queensland, Australia cost AUD \$175 million. However, if the ants had not been managed they would have caused AUD \$8.9 billion of damage to the Australian economy over 30 years. ${ }^{165}$ Managing invasive species can also be a cheap way to secure ecosystem services. In South Africa, a country which suffers from droughts and where millions of people do not have access to potable water, about $9 \%$ of the country's water was lost to invasive tree species. An analysis showed that removing the trees was a lower-cost way to increase water supplies than building new dams. ${ }^{166}$

\subsubsection{Prevention}

Prevention is the first line of defence against invasive species, and is generally the most costeffective $^{167}$ - once an alien species has become a widespread invasive, the economic and often environmental costs of eradicating the invader, or even reducing it to a modest level, can be prohibitive. ${ }^{168}$ Prevention is more difficult against unintended introductions, and its effectiveness depends on a number of factors such as the salary and training of biosecurity personnel, and having appropriate facilities such as fumigation chambers, inspection apparatus, and quarantine areas. ${ }^{169}$ The rate of invasions can be further reduced by backing up the border control system with surveillance around the entry points to allow early detection and immediate eradication of new incursions. ${ }^{170}$ Biosecurity needs to be performed internally as well as on international borders to stop invasive species spreading within a country. ${ }^{171}$

\footnotetext{
${ }^{165}$ It is estimated there were 65,000 colonies of fire ants across 30,000 hectares of land when the eradication project began in 2001.

Genevieve Hussey, "Fire Ant Battle," Radio Australia, June 11, 2007, http://www.abc.net.au/ra/innovations/stories/s1928616.htm.

${ }^{166}$ CBD Executive Secretary, Invasive Alien Species, Case-studies and Country Comments on Invasive Alien Species, 22-23.

Department of Water Affairs, "Welcome to the Working For Water Webpage," n.d., http://www.dwaf.gov.za/wfw/.

${ }^{167}$ CBD Executive Secretary, Invasive Alien Species, Case-studies and Country Comments on Invasive Alien Species, 12.

${ }^{168}$ McNeely et al., A global strategy on invasive alien species, 24.

169 lbid., 25.

${ }^{170}$ CBD Executive Secretary, Invasive Alien Species, Case-studies and Country Comments on Invasive Alien Species, 15.

${ }^{171}$ Paini et al., "Threat of invasive pests from within national borders," 2.
} 


\subsubsection{Eradication}

Eradication means completely eliminating all individuals of an invasive species. While this can be expensive, especially eradicating the last few individuals, the benefits tend to be permanent as long as re-invasions are prevented. Eradication methods include: mechanical (physical removal by hand or machine, use of firearms or traps); chemical (use of herbicides, insecticides, or rodenticides); habitat management (such as prescribed burning or grazing); and biological (releasing sterile males of the target species, inducing resistance in the host, or releasing natural enemies of the target species). ${ }^{172}$

The latter method is known as biocontrol, and while it can be a valuable (as well as cheap and self-sustaining) option, it also involves some risks:

- The Indian Mongoose was introduced to Fiji, Hawaii, the West Indies, and Mauritius in the late 1800 s to control rats, particularly in sugar cane fields. The mongoose controlled the Asiatic rat but not the European rat, ${ }^{173}$ and preyed heavily on native ground nesting birds, mammals, reptiles, amphibians, and invertebrates. The mongoose is also a vector for rabies. ${ }^{174}$

- The giant African Snail was introduced to the Pacific, the Caribbean and parts of Asia as a source of protein for human consumption. ${ }^{175}$ However, it became a major agricultural pest, and so the carnivorous Rosy Wolf Snail was introduced from the 1950s onwards as a biocontrol agent. This fast-moving predator has instead become an ecological disaster and is responsible for a significant loss of endemic snail species. ${ }^{176}$

- In New Zealand ferrets, weasels, and stoats (mustelids) were introduced in the 1880 s to control rabbits and hares. ${ }^{177}$ However, they also prey on native birds (such as the kiwi, yellow-eyed penguin, blue duck, and royal albatross), lizards (such as skinks and geckos), and invertebrates (such as the giant weta), and can carry tuberculosis. The government changed its policy on mustelids in 1903, although it was only in 1936 that all legal protection for mustelids was removed. ${ }^{178}$ These animals continue to threaten New

\footnotetext{
172 McNeely et al., A global strategy on invasive alien species, 27.

${ }^{173}$ Pimentel, Zuniga, and Morrison, "Update on the environmental and economic costs associated with alieninvasive species in the United States," 276.

${ }^{174}$ Lowe et al., 100 of the World's Worse Invasive Alien Species: A selection from the Global Invasive Species Database, 10.

175 Sanu and Newport, "Invasive alien species dispersal," 293.

${ }^{176}$ Lowe et al., 100 of the World's Worse Invasive Alien Species: A selection from the Global Invasive Species Database, 10.

${ }^{177}$ Rabbits and hares were themselves introduced species that had become serious agricultural pests by the mid1870s.

${ }^{178}$ Department of Conservation (DOC), "Weasels," n.d., http://www.doc.govt.nz/conservation/threats-andimpacts/animal-pests/animal-pests-a-z/weasels/.
} 
Zealand's biodiversity, and some native species, such as the kakapo, are only found on mustelid-free islands. ${ }^{179}$

\subsubsection{Sustained control}

The same methods that are used for eradication can also be used to control invasive species by reducing their populations to acceptable thresholds. Other control methods can include containment measures, such as fencing to protect vegetation from pigs and deer, or quarantine islands. ${ }^{180}$ In the long run effective suppression is more expensive than a successful eradication programme. ${ }^{181}$

Prevention, eradication, and control can be very costly so countries, especially developing countries, need to prioritise their efforts so that scarce resources are targeted to where they will achieve optimal benefits. ${ }^{182}$ Legislation can also be an important strategy to prevent invasions, such as making it illegal to keep certain species of plants and fish in aquariums, and ensuring high standards for ship anti-fouling and ballast water discharges. ${ }^{183}$

\subsection{Summary}

As has been shown, invasive species can have large and wide-ranging impacts on economies, societies, and the environment. They are the number one driver of biodiversity loss on islands, and can undermine livelihoods and ecosystem services upon which all people, but especially subsistence fishers and farmers, depend on for their survival. Indeed, as Ministers at the 21st Meeting of the Pacific Regional Environment Programme (SPREP) noted recently, biological diversity is the foundation of the well-being of Pacific communities and cultures. ${ }^{184}$

It is possible to conceptualise invasive species in a number of ways: they affect biodiversity; national economies, trade, and livelihoods; food security; climate change adaptation; human health; culture and traditions; well-being from ecosystem services; and they are a biosecurity issue. Invasive species are thus not "just an environmental issue". Rather they have ramifications throughout modern economies and societies, involving such issues as global

\footnotetext{
${ }^{179}$ Department of Conservation (DOC), "Ferrets," n.d., http://www.doc.govt.nz/conservation/threats-andimpacts/animal-pests/animal-pests-a-z/ferrets/.

${ }^{180}$ CBD Executive Secretary, Invasive Alien Species, Case-studies and Country Comments on Invasive Alien Species, 19.

${ }^{181}$ Global Invasive Species Programme (GISP), "Ecology and Management of Invasive Alien Species:

Management," 2008, http://www.gisp.org/ecology/strategies.asp.

182 Ibid., 25.

183 Hulme, "Trade, transport and trouble," 15.

${ }^{184}$ Secretariat of the Pacific Regional Environment Programme (SPREP), "Pacific Environment Ministers' Communique," September 9, 2010, http://www.sprep.org/article/news_detail.asp?id=822.
} 
trade, agriculture, economics, health, water management, development, and climate change. In other words, the issue of invasive species goes to the heart of the problems most politicians are spending much time debating, although usually without reference to invasive species. ${ }^{185}$ As Achim Steiner, Executive Director of the United Nations Environment Programme (UNEP) stated: "far too many governments have failed to grasp the scale of the threat from invasive species, or are far too casual in their response". ${ }^{186}$

\footnotetext{
${ }^{185}$ McNeely, "Invasive species," 1.

186 Steiner, "Counting the cost of alien invasions."
} 


\section{Regional architecture for invasive species management in the Pacific}

It is important that islands turn their geographic isolation into an advantage to prevent the spread of invasive species. ${ }^{187}$ Because of the scale of the problem, and the multiple sources $^{188}$ and causes ${ }^{189}$ of invasions it is important to have a multi-country, regional, or even global approach to managing invasive species in a strategic, timely, and holistic manner. This allows countries and organisations to coordinate efforts and avoid duplication, pool resources and experiences, as well as legislate for and enforce agreed standards and protocols.

Additional reasons to cooperate include:

- Achieving economies of scale, where the cost per person of providing a service can be reduced if the number of people benefiting from the service is increased;

- Donors may not want to see the development gains from agriculture, health etc lost to invasive species; and

- Management programmes may be ineffective unless bordering countries also act to stop repeated re-invasions. ${ }^{190}$

Pacific Island countries and territories have realised the shortcomings of having very few skilled people at a national level, which is why they have a regional approach. ${ }^{191}$

This chapter investigates the international, regional, and national context of invasive species management in the Pacific. While there appears to be many conventions, organisations, and work programmes relevant to invasive species, many of them have very small staffs and limited budgets. Invasive species, if they feature at all in regional plans, tend to have far less

\footnotetext{
187 IUCN/SSC Invasive Species Specialist Group (ISSG), IUCN guidelines for the prevention of biodiversity loss caused by alien invasive species, 3 .

188 Including the national and international movements of people and goods by air, ground, or sea; forestry, horticulture, and aquaculture; construction projects; and the pet trade.

189 Including the use of exotic species in a wide range of economic activities, the conversion and fragmentation of habitat, the liberalisation/deregulation of markets, the expansion in the trade of goods and services, and the increasing mobility of people.

Perrings, "The economics of biological invasions," 2.

${ }^{190}$ Meyerson and Mooney note it is far more effective to help other countries control or prevent invasive species at their source than try to prevent their importation.

Meyerson and Mooney, "Invasive alien species in an era of globalization," 207.

191 Shyama Pagad, "Invasive Species Specialist Group (IUCN-ISSG)," interview by Simon Lovatt, February 9 , 2011.
} 
prominence than, and almost no connection with, the main sources and pathways of their spread - international trade and tourism, infrastructure projects, and economic activities such as aquaculture and horticulture.

Please note that the actual implementation of invasive species management initiatives is undertaken by PICT government and civil society actors. All other regional actors serve as coordinators, enablers, facilitators, capacity builders, networkers, funders etc (refer to Figure 1).

\subsection{International context}

Because invasive species issues influence such a wide variety of sectors (agriculture, human health, environment etc), no single international agreement will provide comprehensive policy coverage. ${ }^{192}$ The major international treaties relating to invasive species include the Convention on Biological Diversity (CBD), the International Plant Protection Convention (IPPC), and the Convention on Wetlands of International Importance, especially as Waterfowl Habitat (Ramsar). Major international organisations include the International Maritime Organisation (IMO), and the World Trade Organisation (WTO).

\subsubsection{International conventions}

\section{Convention on Biological Diversity (CBD)}

The $\mathrm{CBD}^{193}$ is an international treaty enacted in 1993 that addresses the global loss of biodiversity, and recognises threats at multiple levels - genes, species, habitats, and ecosystems. Article $8(\mathrm{~h})$ of the CBD states that "each Contracting Party shall, as far as possible and as appropriate, prevent the introduction of, control or eradicate those alien species which threaten ecosystems, habitats or species." ${ }^{194}$ This is a binding but broadly phrased obligation, which leaves Parties free to choose appropriate means by which to implement it. ${ }^{195}$ As of 2008 , only $55 \%$ of the 193 Parties $^{196}$ had relevant invasive species

\footnotetext{
192 Jamie Reaser et al., "Environmental Diplomacy and the Global Movement of Invasive Alien Species: A U.S. Perspective," in Invasive species: vectors and management strategies, ed. Gregory M. Ruiz and James T. Carlton (Washington D.C.: Island Press, 2003), 371.

${ }^{193}$ Convention on Biological Diversity, 2011, http://www.cbd.int/.

194 Convention on Biological Diversity (CBD), "Article 8. In-situ Conservation," March 30, 2007, http://www.cbd.int/convention/articles/?a=cbd-08.

${ }^{195}$ Clare Shine, Nattley Williams, and Lothar Gündling, A guide to designing legal and institutional frameworks on alien invasive species, Environmental policy and law paper, IUCN environmental policy and law paper (Gland, Switzerland,: International Union for Conservation of Nature (IUCN), 2000), 14, http://data.iucn.org/dbtwwpd/edocs/EPLP-040-En.pdf.

${ }^{196}$ Andorra and the Holy See have not signed the Convention. The USA has signed the Convention but has not ratified it.

Convention on Biological Diversity (CBD), "List of Parties," n.d., http://www.cbd.int/convention/parties/list/.
} 
legislation, and, according to McGeoch et al., those that did often had inadequate strategies, insufficient management plans, and ineffective implementation of such plans. ${ }^{197}$

The Cartagena Protocol on Biosafety (2000) is a further protocol to the CBD, and seeks to protect biological diversity from the potential risks posed by living modified organisms resulting from modern biotechnology.

\section{International Plant Protection Convention (IPPC)}

The IPPC ${ }^{198}$ aims to protect plant biodiversity by preventing the spread and introduction of pests of all plants ${ }^{199}$ and plant products through the use of sanitary and phytosanitary (SPS) measures. The convention includes both direct and indirect damage by pests so it includes weeds, and it also covers vehicles, aircraft, vessels, containers, storage places, soil, and other objects or material that can harbour or spread pests. ${ }^{200}$ Parties to the IPPC are required to adopt legislative, technical, and administrative procedures and standards to identify pests, assess their risks, and prevent their introduction and spread. Parties are also required to distribute information regarding plant pests and means of prevention and control. ${ }^{201}$

\section{The Ramsar Convention on Wetlands}

The Ramsar Convention on Wetlands ${ }^{202}$ addresses issues relating to freshwater, estuary, and coastal ecosystems (including coral reefs, mangroves, and sea grass beds). ${ }^{203}$ The original 1971 convention does not contain any explicit provision on alien invasive species. However, in 1999 the Invasive Species and Wetlands resolution (Resolution VII.14) was adopted which emphasises the threat that alien species pose to the ecological character of wetlands and to wetland species. ${ }^{204}$ The resolution urges Parties to prepare an inventory and risk assessment of alien species in wetlands and to establish programmes to target priority invasive species for control or eradication. It also urges Parties to address the environmental,

\footnotetext{
${ }^{197}$ McGeoch et al., "Global indicators of biological invasion," 100,104.

198 International Plant Protection Convention (IPPC), n.d., https://www.ippc.int/.

${ }^{199}$ i.e. native plants as well as cultivated ones.

200 International Plant Protection Convention (IPPC), "Convention, model instruments and related information," January 21, 2010, https://www.ippc.int/index.php?id=convention\&no_cache=1\&L=0.

${ }^{201}$ Shine, Williams, and Gündling, A guide to designing legal and institutional frameworks on alien invasive species, 23.

202 The Ramsar Convention on Wetlands, n.d., http://www.ramsar.org/cda/en/ramsarhome/main/ramsar/1_4000_0_.

203 The Ramsar Convention on Wetlands, "Resolution VIII.11: Additional guidance for identifying and designating under-represented wetland types as Wetlands of International Importance," November 2002 http://www.ramsar.org/cda/en/ramsar-documents-resol-resolution-viii-11/main/ramsar/1-31107\%5E21521_4000_0_.

204 The Ramsar Convention on Wetlands, "Resolution VII.14: Invasive species and wetlands," May 1999, http://www.ramsar.org/cda/en/ramsar-documents-resol-resolution-vii-14/main/ramsar/1-31107\%5E20830_4000_0_.
} 
economic, and social impact of the movement and transport of alien species on the global spread of invasive wetland species.

\subsubsection{International organisations}

\section{International Maritime Organisation (IMO)}

The $\mathrm{IMO}^{205}$ is the United Nations specialised agency responsible for the safety and security of shipping and the prevention of marine pollution by ships. The IMO potentially plays a very important role in invasive species management, as more than $90 \%$ of global trade is carried by sea. ${ }^{206}$ The IMO aims to stop the spread of invasive species through the International Convention for the Control and Management of Ships' Ballast Water and Sediments. This requires all ships to implement ballast water management systems (such as exchanging ballast water in ocean far away from land ${ }^{207}$ ) in order to reduce the estimated 10,000 species that are transported in ballast water every day. ${ }^{208}$ The IMO is also preparing draft guidelines for the control and management of ships' biofouling (where organisms attach themselves to ship surfaces), which is another major route for invasive species. ${ }^{209}$ Over 2,000 species have been associated with biofouling, any number of which could be present on the average 3,000 international vessels that arrive in New Zealand annually. ${ }^{210}$

\section{World Trade Organisation (WTO)}

The $\mathrm{WTO}^{211}$ seeks to liberalise international trade, and provides binding rules to ensure that governments extend free market access to each others products and services. ${ }^{212}$ One of the WTO agreements relevant to invasive species is the Agreement on the Application of Sanitary and Phytosanitary Measures (SPS Agreement). ${ }^{213}$ This allows Members to:

\footnotetext{
205 International Maritime Organization (IMO), 2010, http://www.imo.org/Pages/home.aspx.

206 International Maritime Organization (IMO), "Introduction to IMO," 2010, http://www.imo.org/About/Pages/Default.aspx.

207 MAF Biosecurity New Zealand, "Importing Ballast Water from all Countries," June 13, 2005, http://www.biosecurity.govt.nz/imports/non-organic/standards/ballastwater.htm.

208 Hulme, "Trade, transport and trouble," 13.

209 International Maritime Organization (IMO), "Sub-Committee on Bulk Liquids and Gases (BLG), 14th session: 8 to 12 February 2010," February 2010, http://www.imo.org/MediaCentre/MeetingSummaries/BLG/Pages/BLG-14thSession.aspx.

${ }^{210}$ Andrew Bell et al., Risk Analysis: Vessel Biofouling (Wellington, New Zealand: Ministry of Agriculture and Forestry, February 15, 2011), 3,4, http://www.biosecurity.govt.nz/files/regs/imports/risk/vessel-biofouling-riskanalysis-0211.pdf.

${ }^{211}$ World Trade Organization (WTO), n.d., http://www.wto.org/.

212 Shine, Williams, and Gündling, A guide to designing legal and institutional frameworks on alien invasive species, 24-27.

${ }^{213}$ World Trade Organisation (WTO), "The WTO Agreement on the Application of Sanitary and Phytosanitary Measures (SPS Agreement)," n.d., http://www.wto.org/english/tratop_e/sps_e/spsagr_e.htm.
} 
- adopt national measures or standards to protect human, animal, and plant life and health from the risks arising from the entry, establishment, or spread of pests, diseases, diseasecarrying or disease-causing organisms; and

- prevent or limit other damage within the territory of the Member from the entry, establishment, or spread of pests.

Members who do apply SPS measures must make sure they are based on scientific risk assessments, ${ }^{214}$ be the option least restrictive to trade (i.e. only applied to the extent necessary to protect human, animal, or plant life or health), be transparent, and nondiscriminatory.

Although there is provision for the precautionary principle in the SPS Agreement (Article 5, paragraph 7), ${ }^{215}$ in this author's opinion this does not adequately cover the potential for alien species that are currently benign to become invasive in the future. ${ }^{216}$ McNeely notes that risk assessments can often be extremely expensive - the risk assessment for the proposed import of raw Siberian larch cost the USA Government about USD $\$ 500,000 .^{217}$ This cost is probably prohibitively expensive for developing nations. Also, there is currently no SPSrecognised source of international standards regarding general environmental and biodiversity protection against alien invasive species, except the IPPC as it relates to plant pests. $^{218}$

\subsection{Regional context}

At a regional level, there are several layers of strategies, organisations, and programmes working on invasive species, as well as NGOs, private foundations, state donors, and

\footnotetext{
${ }^{214}$ Risk assessment asks what could go wrong, how likely is it to go wrong, and what would the consequences be? For example, if Tonga wanted to export pineapples to New Zealand, New Zealand would need to find out what species Tonga has that New Zealand does not, and what steps, such as fumigation, need to be taken to mitigate these risks.

MAF Biosecurity New Zealand, Balance in Trade: Understanding how the Sanitary and Phytosanitary (SPS) Agreement helps protect New Zealand's people, economy and environment while improving trade opportunities (Wellington, New Zealand: Ministry of Agriculture and Forestry, 2009), http://www.biosecurity.govt.nz/files/biosec/policy-laws/intl/sps/resources/new-zealand/balance-in-trade.pdf.

215 "In cases where relevant scientific evidence is insufficient, a Member may provisionally adopt sanitary or phytosanitary measures on the basis of available pertinent information, including that from the relevant international organizations as well as from sanitary or phytosanitary measures applied by other Members. In such circumstances, Members shall seek to obtain the additional information necessary for a more objective assessment of risk and review the sanitary or phytosanitary measure accordingly within a reasonable period of time."

World Trade Organisation (WTO), "The WTO Agreement on the Application of Sanitary and Phytosanitary Measures (SPS Agreement)."

${ }^{216}$ See Doyle, "Invasive Species Lie in Wait, Strike After Decades."

217 McNeely, "Invasive species," 10.

218 Shine, Williams, and Gündling, A guide to designing legal and institutional frameworks on alien invasive species, 30.
} 
technical assistance agencies. The Pacific Plan is the overarching development framework for the region, with action strategies for biodiversity conservation, food security, and climate change providing more precise goals and objectives on specific aspects of the Pacific Plan. The Guidelines for Invasive Species Management in the Pacific provide a list of best-practice steps that invasive species projects should follow.

Supporting PICT governments and civil society to implement invasive species management initiatives is the Roundtable for Nature Conservation in the Pacific Islands. This is a coalition of more than 50 organisations working on conservation in the Pacific. One of the eight working groups of the Roundtable is the Pacific Island Partnership (PIP), which focuses on invasive species issues. PIP seeks to coordinate the actions of its various members, including the two regional programmes: the Pacific Invasives Initiative (PII) and the Pacific Invasives Learning Network (PILN). Three regional intergovernmental agencies are also involved with invasive species work: the Secretariat of the Pacific Regional Environment Programme (SPREP), the Secretariat of the Pacific Community (SPC), and the University of the South Pacific (USP), who cover biodiversity, biosecurity and trade, and education issues respectively. Other regional actors include state donor agencies, technical assistance agencies, private foundations, and NGOs. ${ }^{219}$ Additionally, the Pacific Ant Prevention Programme (PAPP) and the Pacific Plant Protection Organisation (PPPO) focus on specific aspects of invasive species and are both hosted by SPC.

A simplified schematic of the various strategies and actors involved in invasive species management in the Pacific is shown in Figure 1.

\subsubsection{Regional plans and actions strategies}

\section{The Pacific Plan}

The Pacific Plan ${ }^{220}$ is the overarching strategy for strengthening regional coordination and sustainable development in the Pacific. It provides the direction, priorities, and targets that all regional intergovernmental agencies must follow, but is only a guide for PICTs, other donor governments, and non-state actors to work towards. The Pacific Plan was endorsed by Pacific Islands Forum ${ }^{221}$ leaders in 2005 , and had four key objectives: economic growth, ${ }^{222}$

\footnotetext{
219 The role of private foundations and NGOs will not be examined in this research.

${ }^{220}$ Pacific Islands Forum Secretariat, The Pacific Plan - for strengthening regional cooperation and integration (Port Moresby, PNG: Pacific Islands Forum, 2007), http://www.forumsec.org.fj/resources/uploads/attachments/documents/Pacific_Plan_Nov_2007_version.pdf.

${ }^{221}$ Australia, Cook Islands, FSM, Kiribati, Nauru, New Zealand, Niue, Palau, PNG, Republic of Marshal Islands, Samoa, Solomon Islands, Tonga, Tuvalu and Vanuatu. Fiji was suspended for the Forum on 2 May 2009.

222 Defined as sustainable, pro-poor economic growth.
} 


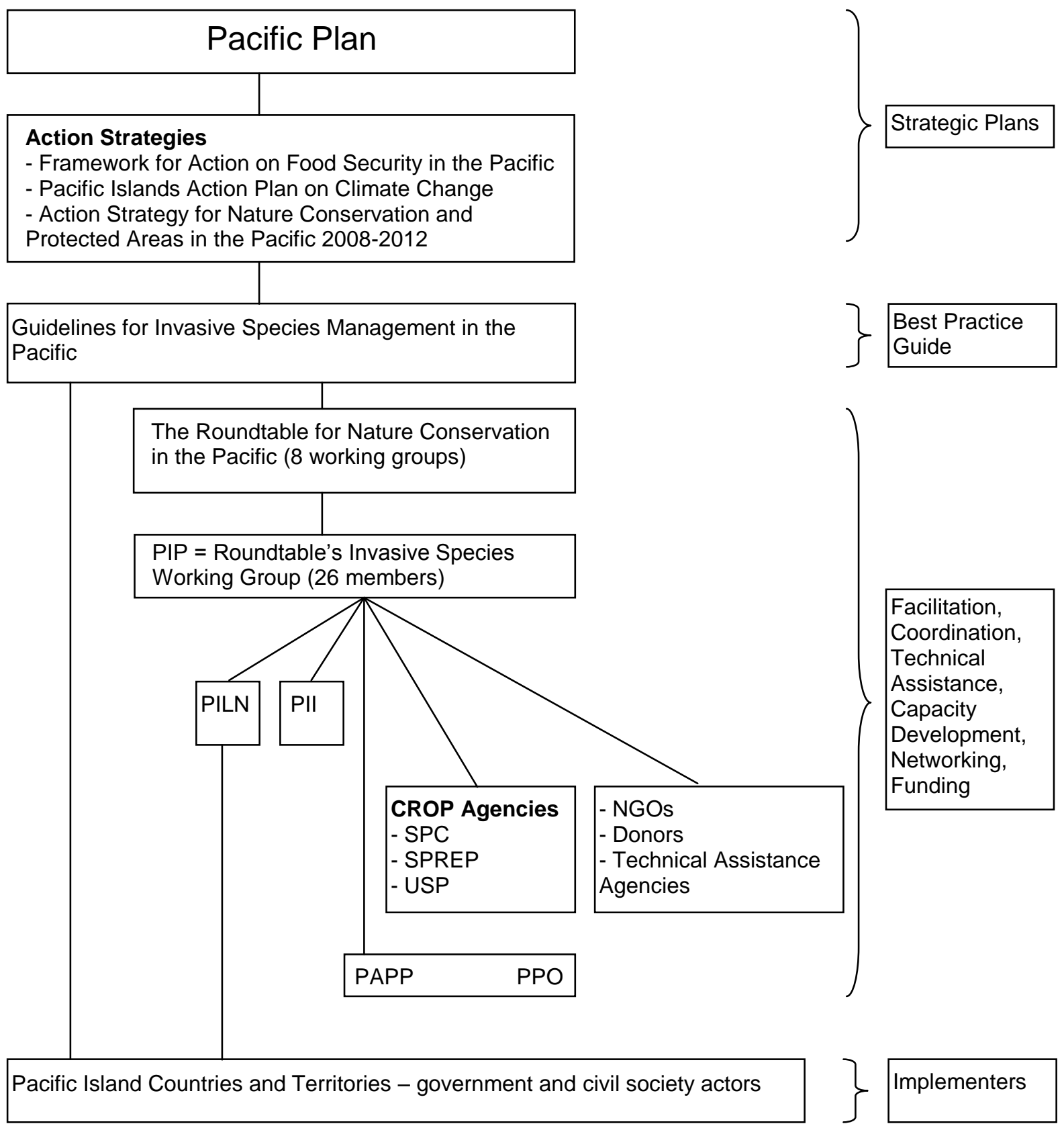

Figure 1. Simplified overview of invasive species management in the Pacific. The Pacific Plan provides the overarching strategy for development in the region, and is supported by various action plans. These plans are not binding on NGOs, donors, and technical assistance agencies. The Guidelines for Invasive Species Management in the Pacific provides a best-practice guide for managing invasive species. Pacific Island Countries and Territories implement invasive species management initiatives, and are assisted by members of the Roundtable for Nature Conservation in the Pacific. PILN is the main network that countries and territories can use to communicate their needs to the appropriate regional agencies.

Note: not all interactions are shown. For example Pacific Island Countries and Territories can request help directly from PII, the CROP agencies, NGOs, donors, and technical assistance agencies. The other actors also communicate with and assist each other directly.

CROP - Council of Regional Organisations of the Pacific; SPC - Secretariat of the Pacific Community; SPREP - Secretariat of the Pacific Regional Environment Programme; PAPP - Pacific Ant Prevention Programme; PILN - Pacific Invasives Learning Network; PII - Pacific Invasives Initiative; PIP - Pacific Invasives Partnership; PPO - Pacific Plant Protection Organisation; USP - University of the South Pacific. 
sustainable development, ${ }^{223}$ good governance, ${ }^{224}$ and security. ${ }^{225}$ Management of the natural environment, biodiversity conservation, and protection of the environment are not the central themes of the Pacific Plan. ${ }^{226}$ Of particular concern to this author is the almost total absence of any reference to invasive species.

The key goals of the Economic Growth objective include increased trade of goods and services including labour, enhanced transportation infrastructure (roads, shipping, and airports), and increased tourism. ${ }^{227}$ A 2007 decision also requested SPC to develop a new agriculture and forestry initiative, including atoll agriculture. ${ }^{228}$ As noted earlier in this report, all of these are potential routes for the unintentional transfer of invasive species.

Sustainable Development ${ }^{229}$ goals include decreasing poverty, improving education, and gender equality. Health is mentioned in the context of HIV/AIDS and immunisations against target diseases, but health concerns caused by ants, rats, parasites of freshwater snails, or other invasive species are not referred to. The success indicators of the Improved Natural Resource and Environmental Management objective were maintaining the same area of native forests, mangroves, and coral reefs; but there was no mention of the fact that those areas might potentially be full of invasive species. There was also a call for increasing the area of ecosystems under conservation management which is welcome, but it is unclear if "management" means for example halting illegal logging, or if it extends to invasive species eradications as well. Cultural values and traditional knowledge were mentioned in the context of maintaining the number of people whose livelihoods depend on the use of traditional products and protecting intellectual property rights, rather than recognising the impact invasive species can have on cultural practices and knowledge.

The only explicit mention of invasive species is in the Security objective where one of the success indicator states that no new plant and animal species have been introduced. ${ }^{230}$ However, this is in the context of international border security, which while appropriate for a regional plan, does not address the spread of invasive species within PICTs, or the potential

\footnotetext{
${ }^{223}$ Defined as the integration and mutual reinforcement between the three pillars of economic development, social development, and environment conservation (where conservation is defined as wise use, including protection, in some circumstances).

${ }^{224}$ Defined as the transparent, accountable and equitable management of all resources.

${ }^{225}$ Defined as the stable and safe social (or human) and political conditions necessary for, and reflective of, good governance and sustainable development for the achievement of economic growth.

${ }^{226}$ Secretariat of the Pacific Regional Environment Programme (SPREP), Action Strategy for Nature Conservation and Protected Areas in the Pacific islands region 2008-2012: empowering local people, communities and Pacific institutions (Apia, Samoa: Roundtable for nature conservation in the Pacific Islands, 2009), 23, http://www.sprep.org/att/publication/000755_RoundtableActionStrategy.pdf.

${ }^{227}$ Pacific Islands Forum Secretariat, The Pacific Plan, 22-23.

228 Ibid., 47.

229 lbid., 25-32.

230 lbid., 34.
} 
for currently benign alien species to become invasive if environmental conditions change. There is also no mention of eradication of established species.

At the 2009 Pacific Island Forum meeting in Cairns, Australia, five key themes and priorities were endorsed by leaders for the 2010-2012 Pacific Plan period. ${ }^{231}$ These were:

- fostering economic development and promoting opportunities for broad-based growth;

- improving livelihoods and the well-being of Pacific peoples;

- addressing the impacts of climate change;

- achieving stronger national development through better governance; and

- ensuring improved social, political, and legal conditions for stability, safety, and security.

These priorities potentially have risks for invasive species issues if not managed properly. For example, initiatives under the Fostering Economic Development objective include: providing greater support to tourism by improving access to Pacific destinations by air and sea; fostering greater international and intra-regional trade opportunities by working to allow for the freer movement of goods and services; addressing issues that hinder the movement of goods and services through expediting fit-for-purpose solutions in the transport sector; and increasing support for infrastructure development across the region. Under Improving Livelihoods and Wellbeing are efforts to better ensure food security by supporting agriculture, aquaculture, and fisheries. I am not saying these initiatives are bad (on the contrary - they are essential for achieving development goals), but serious attention needs to be paid to impacts they could have on invasive species. Possibly the initiative with the most potential to acknowledge invasive species is the initiative to address the impacts of climate change by enhancing the resilience of ecological systems and associated biodiversity in line with the Year of Biodiversity in $2010 .^{232}$

\section{Other regional strategies}

At least three regional strategies specifically mention invasive species, demonstrating some recognition of the wide-ranging nature of their impacts:

- The Action Strategy for Nature Conservation in the Pacific Islands Region $2008-2012^{233}$ is the regional strategy for biodiversity conservation that all parties involved in conservation in the Pacific are encouraged to align with. It highlights the priority concerns for

\footnotetext{
${ }^{231}$ Pacific Islands Forum Secretariat, Pacific Plan 2010 Annual Progress Report (Pacific Islands Forum, 2010), 4, http://www.forumsec.org/resources/uploads/attachments/documents/Pacific Plan 2010 Annual Progress Report_Eng.pdf.

${ }^{232}$ Ibid., 16-18.

${ }^{233}$ Secretariat of the Pacific Regional Environment Programme (SPREP), Action Strategy for Nature Conservation and Protected Areas in the Pacific Islands region 2008-2012.
} 
conservation in the region, and outlines a roadmap for achieving the key goals. ${ }^{234}$ The Action Strategy's fourth objective is to "manage threats to biodiversity, especially climate change impacts and invasive species".

- Towards A Food Secure Pacific: Framework for Action on Food Security in the Pacific $(2011-2015)^{235}$ is the regional strategy for food security. "Strengthening biosecurity and quarantine systems to curb the import of invasive species, pests, and diseases and to respond as necessary at national and regional levels" is suggested as a potential action to increase the production, productivity, and resilience of agriculture and fisheries' systems. ${ }^{236}$ This focus is important as other potential actions in the strategy recognise that reliable and affordable transport systems are essential for food security (particularly in the Pacific where $98 \%$ of the region is covered by ocean and a large amount of food is imported), ${ }^{237}$ but do not mention that invasive species can spread through these same transport systems.

- The Pacific Islands Action Plan on Climate Change 2006-2015 specifically mentions developing and implementing measures against introduced and invasive species as a national action for climate change adaptation. ${ }^{238}$ Interestingly, the Pacific Islands Framework for Action on Climate Change 2006-2015 does not mention invasive species specifically, although it does suggest establishing integrated coastal management and adaptation measures to increase the resilience of coastal systems; protecting, amongst other things, coral reefs, coastal communities, and mangroves; and diversifying economic opportunities in agriculture, biodiversity conservation, and management. ${ }^{239}$

Within these three regional strategies there is no reference to how the invasive species initiatives of the various strategies might coordinate and collaborate with one another. There is also no specific information on how to manage invasive species. Presumably this is to be done in accordance with the Guidelines for Invasive Species Management in the Pacific, ${ }^{240}$

\footnotetext{
234 The Action Strategy includes Principles for Nature Conservation in the Pacific (essentially a code of conduct), and Guidelines for implementation of Community Conservation Programmes (which are fundamental elements to successful conservation such as community ownership and participation, capacity building, political commitment, and sustained funding).

235 The Food Secure Pacific Working Group, Towards A Food Secure Pacific: Framework for Action on Food Security in the Pacific (Fiji: Food Secure Pacific, June 1, 2010), http://www.foodsecurepacific.org/documents/FINAL TOWARDS A FOOD SECURE PACIFIC_June1.pdf.

236 Ibid., 26.

237 Ibid., 39-41.

238 Secretariat of the Pacific Regional Environment Programme (SPREP), Pacific Islands Action Plan on Climate Change 2006-2015 (Apia, Samoa: SPREP, n.d.), 2, http://www.sprep.org/legal/documents/APClimateChange.pdf.

${ }^{239}$ Secretariat of the Pacific Regional Environment Programme (SPREP), Pacific Islands Framework for Action on Climate Change 2006-2015 (Apia, Samoa: SPREP, n.d.), 7, http://www.sprep.org/climate_change/pycc/documents/PIFACC.pdf.

${ }^{240}$ Tye, Guidelines for invasive species management in the Pacific.
} 
which lists the essential components for successful invasive species management programmes in the Pacific. These are:

- generating support (including raising awareness about the wide range of impacts of invasive species);

- building capacity (including developing skills, institutions, infrastructure, and peer networks);

- legislation, policy, and protocols (ensuring appropriate legislation is in place and operating);

- baseline and monitoring (establishing the status and distribution of invasive species, and a system to detect trends and emerging threats);

- prioritisation (establishing risk assessments and prioritising species for management);

- research on priorities (understanding the biology and possible impacts of priority species, and developing effective management techniques);

- biosecurity (preventing the spread of invasive species across internal and external borders). Note: this includes preventing the intentional or unintentional export of priority invasive species.

- management of established invasive species (undertaking eradication, suppression, or containment programmes); and

- restoration.

\subsubsection{Regional actors and organisations}

\section{The Roundtable for Nature Conservation in the Pacific}

The Roundtable for Nature Conservation in the Pacific ${ }^{241}$ is a coalition of over 50 organisations and governments working on conservation in the region. Members of the Roundtable include:

- the regional intergovernmental organisations;

- $\quad$ PICT agencies;

- donors agencies;

- private foundations;

- international, regional, and national NGOs;

- technical assistance agencies; and

- regional and international organisations.

\footnotetext{
${ }^{241}$ Roundtable for Nature Conservation in the Pacific Islands, "Roundtable Home," n.d., http://www.sprep.org/Roundtable/.
} 
The two main roles of the Roundtable are to coordinate the actions of its various members to increase their effectiveness; and to promote, facilitate, and monitor the implementation of the Action Strategy for Nature Conservation in the Pacific Islands Region 2008-2012.

\section{The Pacific Invasives Partnership (PIP)}

The Pacific Invasives Partnership (PIP) is the Roundtable's invasive species working group. It is the regional partnership that coordinates agencies working on aspects of invasive species in more than one country or territory of the Pacific. There are currently 26 members ${ }^{242}$ of PIP who have a combined capacity for peer networking, technical advice and support, project planning, training, processes and tools, funding, research, information, policy, and coordination. ${ }^{243}$ PIP also provides guidance and support to the two main invasive species programmes in the region: the Pacific Invasives Initiative (PII) and the Pacific Islands Learning Network (PILN).

\section{Pacific Invasives Initiative (PII)}

$\mathrm{PII}^{244}$ is the first regional programme of the Cooperative Islands Initiative (CII), a global initiative launched by the New Zealand Government and Invasive Species Specialist Group of the International Union for Conservation of Nature (IUCN-ISSG) in 2002 which aims to disseminate best-practise on invasive species management and to increase capacity and coordination for invasive species on islands. PII was established in 2004 and its main function is to increase the capacity (and enthusiasm) of Pacific agencies for invasive species management, with the eventual aim of building a large pool of people within the region who are able to carry out invasive species management projects (such as single mammal eradications), with outside personnel only being called on for more complex eradication projects. Being based at Auckland University, it is able to easily access New Zealand expertise from universities, agencies such as the Department of Conservation (DOC) and Landcare Research, and commercial companies which greatly assists in PIl's effectiveness. PII is then able to adapt and customise that knowledge and transfer it to the Pacific. As Souad Boudjelas, PII Programme Manager explained:

"Other agencies are sitting close to the problem; we are sitting close to where the technical know-how and experience is and we are able to transfer these to the Pacific." 245

\footnotetext{
242 Including IDG MFAT, DOC, and Landcare Research. MAF is not a member of PIP.

243 Souad Boudjelas, "Meeting the Invasive Species Challenge in the Pacific Region," in (presented at the Helping Islands Adapt workshop, Auckland, New Zealand, 2010), 10, www.conference.co.nz/files/docs/pacific presentation for is workshop april 2010 final.pdf.

244 Pacific Invasives Initiative (PII), February 24, 2011, http://www.issg.org/cii/pii/index.html.

245 Souad Boudjelas, "Pacific Invasives Initiative (PII)," interview by Simon Lovatt, January 26, 2011.
} 
This relationship also helps New Zealand agencies communicate with the Pacific efficiently, enabling them to be helpful but without drawing too many resources. PII has four staff.

\section{Pacific Islands Learning Network (PILN)}

PILN $^{246}$ was established in 2006 and is a professional network for invasive species workers in the Pacific. PILN aims to create and build the skills of multi-agency teams in participating countries and territories which work on invasive species projects covering a wide variety of aspects. PILN provides a link between the various country teams to share information, skills, and lessons; as well as conducting training and organising staff exchanges. PILN also acts as a link from countries to regional invasive species services, expertise, and funding that can be provided by NGOs and other agencies, particularly the PIP agencies including the PII.

In summary, PII provides technical support, applied training, access to experts, and peer reviews for projects. PILN promotes peer learning, networking, and the exchange of information. Both PII and PILN contribute to planning, skill sharing, and training in the region, and their work complements that of SPC and SPREP (see below), the lead agencies for invasive species management in the region. ${ }^{247}$

\section{Regional intergovernmental organisations}

There are 11 regional intergovernmental organisations in the Pacific, collectively known as the Council of Regional Organisations of the Pacific (CROP) agencies. ${ }^{248}$ CROP agencies are intergovernmental agencies mandated by the PICTs to provide technical and policy advice and services in their respective areas of expertise, such as fisheries, power, and tourism. The CROP agencies have a collective aim of achieving sustainable development in the PICTs, while working together to prevent overlaps or gaps appearing between the workprogrammes of the various organisations. ${ }^{249}$ In addition to their service and coordination functions, CROP agencies act as an interface between PICTs (who request assistance on matters that CROP agencies cannot deal with in-house) and the four supporting member countries: Australia, France, New Zealand, and the USA (who provide funding, technical advice, and support). The three CROP agencies particularly responsible for invasive species

\footnotetext{
${ }^{246}$ Pacific Invasives Learning Network (PILN), January 2011, http://www.sprep.org/piln/.

247 Pacific Invasives Initiative (PII), The News, November 2008, http://www.issg.org/cii/Electronic\%20references/pii/PII_News/2008/0811 PII News.pdf.

248 They are: Forum Fisheries Agency (FFA), Pacific Islands Development Program (PIDP), Secretariat of the Pacific Community (SPC), Secretariat of the Pacific Regional Environmental Programme (SPREP), southpacific.travel, University of the South Pacific (USP), Fiji School of Medicine (FSCHM), Pacific Islands Forum Secretariat (PIFS), and Pacific Power Association (PPA). The South Pacific Applied Geoscience Commission (SOPAC) recently (1 January 2011) became incorporated into SPC and has been renamed the Applied Geoscience and Technology Division.

${ }^{249}$ Pacific Islands Forum Secretariat, "Council of Regional Organisations in the Pacific (CROP) Charter," April 2000, http://www.spc.int/Coastfish/CROPcharter.htm.
} 
issues are SPREP (natural environment), SPC (biosecurity, trade, and production sectors), and USP (education and training). This multi-agency approach is important to cover the multi-sector nature of invasive species issues.

Secretariat of the Pacific Regional Environment Programme (SPREP)

SPREP, ${ }^{250}$ based in Samoa, is the organisation responsible for environmental protection in the Pacific. It provides services such as technical advice to member countries on request, and environmental advice without request; manages multi-country projects; and is able to source funding that might not be available to individual governments (such as the Critical Ecosystem Partnership Fund (CEPF) which is only available to NGOs and intergovernmental organisations). One of the main functions of SPREP is to ensure that coordination of all actors occurs - SPREP passes on PICT requests and priorities to other organisations, and helps the latter to refine their own niche and in-country programmes.

Ecosystem and species conservation and management (including invasive species) is one of the four priority areas for the SPREP 2011-2015 Strategic Plan. ${ }^{251}$ SPREP has also published the Guidelines for invasive species management in the Pacific, hosts PILN, and coordinates PIP. However, SPREP's work covers a very large range of complex issues such as climate change, pollution, clean water and sanitation, environmental education, and environmental governance which could be a stretch on the organisation's resources. Of the almost 70 staff at SPREP only two work on invasive species: the Invasive Species Advisor (funded by New Zealand's budgetary support) manages SPREP's invasives programme, including coordination of PIP, supervision of PILN, and management of invasives projects; and the other is the PILN coordinator.

SPC

SPC $^{252}$ is the oldest and largest of the CROP agencies. Established in 1947, it has a staff of approximately 600 and has a key focus on sustainable natural resources management and development, sustainable economic development, and sustainable human development. ${ }^{253}$ SPC is involved with invasive species in the production sectors, such as agriculture and forestry. SPC's role is to assist in capacity building in PICTs for biosecurity; provide technical support and advice for surveillance, emergency response plans, and eradication

\footnotetext{
${ }^{250}$ Secretariat of the Pacific Regional Environment Programme (SPREP), 2010, http://www.sprep.org/.

251 Secretariat of the Pacific Regional Environment Programme (SPREP), Agenda Item 6.1: SPREP Strategic Plan 2011 - 2015 (Madang, Papua New Guinea: SPREP, September 2010), 3, http://www.sprep.org/2010SM21/pdfs/eng/Officials/WP_6_1_Strategic Plan 2011-2015.pdf.

252 Secretariat of the Pacific Community (SPC), 2010, http://www.spc.int/.

253 Secretariat of the Pacific Community (SPC), "SPC will be a 'larger organisation' in 2011," October 28, 2010, http://www.spc.int/en/component/content/article/613-spc-will-be-a-larger-organisation-in-2011-.html.
} 
programmes; and maintain and provide relevant information on invasive species to PICTs. SPC also hosts the Pacific Plant Protection Organisation (PPPO), the regional organisation under the IPPC responsible for cooperation in plant protection from invasive species; and coordinates the Pacific Ant Prevention Programme (PAPP), which aims to prevent the entry, establishment, and spread of invasive ant species within and between the PICTs. ${ }^{254}$

Worryingly, despite SPC's size and the importance of the primary production sectors to Pacific economies and livelihoods, there is currently no-one employed to work on invasive species issues - previously there was one position filled but that person has left because of funding limitations. ${ }^{255}$ SPC has also struggled to implement the Pacific Ant Prevention Programme due to funding problems. ${ }^{256}$

University of the South Pacific (USP)

$\mathrm{USP}^{257}$ is the region's university. Established in 1968 it has campuses in each of the member countries, ${ }^{258}$ with the main campus in Laucala, Fiji. The university has a strong programme in invasive species research and education run through the Institute of Applied Science. ${ }^{259}$

\subsubsection{State donors}

The major state donors in the region are Australia, European Union, France, UK, USA, and New Zealand. There does not appear to be much coordination between the various countries apart from their engagement and contributions to the CROP agencies. France provides invasive species assistance to its territories French Polynesia, New Caledonia, and Wallis and Futuna, ${ }^{260}$ and it funded PILN to translate resources into French for the territories. The U.S. Department of Defense is currently designing the Micronesia Biosecurity Plan which has been initiated due to the shifting of 41,000 military and support personnel, as well as equipment and materials from Okinawa, Japan to Guam and CNMI. Having learned from the huge impact that the brown tree snake caused following its transportation on military equipment after World War II, the Micronesia Biosecurity Plan aims to reduce the risks of

\footnotetext{
254 Pacific Invasives Initiative (PII), "Pacific-wide: Pacific Ant Prevention Programme (PAPP)," October 16, 2009, http://www.issg.org/cii/pii/demo/papp.html. Note: while SPC has taken responsibility for managing the PAPP, full implementation of PAPP is multi-sectoral involving many partners including SPREP, PII, Biosecurity New Zealand, and the US Department of Agriculture.

${ }^{255}$ Roy Masamdu to Simon Lovatt, "Secretariat of the Pacific Community (SPC)," February 11, 2011.

${ }^{256}$ Warea Orapa to Simon Lovatt, "Secretariat of the Pacific Community (SPC)," January 17, 2011.

257 University of the South Pacific (USP), 2011, http://www.usp.ac.fj/.

${ }^{258}$ Cook Islands, Fiji, Kiribati, Marshall Islands, Nauru, Niue, Solomon Islands, Tokelau, Tonga, Tuvalu, Vanuatu and Samoa.

259 University of the South Pacific (USP), "Institute of Applied Science," October 14, 2010, http://ias.fste.usp.ac.fj/.

${ }^{260}$ Being French Overseas Territories they are able to access domestic funding rather than having to go through the Foreign Ministry.

Yves Lafoy, "Government of New Caledonia representative,” interview by Simon Lovatt, February 14, 2011.
} 
further introductions of invasive alien species. The goal is to create the most comprehensive regional biosecurity structure in the world. ${ }^{261}$ New Zealand agencies, including the Ministry of Agriculture and Forestry Biosecurity New Zealand (MAFBNZ) and Landcare Research, as well as SPC and USP, have been involved in providing technical advice in the development of the Plan.

\subsubsection{Other actors}

Other international actors that have a role in invasive species issues in the Pacific include the Global Invasive Species Programme (GISP); the Invasive Species Specialist Group of the International Union for the Conservation of Nature (IUCN-ISSG); the Global Environment Facility (GEF); and the United Nations Environment Programme (UNEP). There are also a number of private foundations ${ }^{262}$ and $\mathrm{NGOs}^{263}$ who provide funding, technical advice and support, and implement invasive species management projects in the Pacific, but they are beyond the scope of this research.

\section{Global Invasive Species Programme (GISP)}

GISP $^{264}$ is an international organisation that focuses on policy advice and technical guidance on invasive species. For example, it analyses economic impacts and looks at national legal and institutional issues, as well as providing training manuals, educational material, and country risk assessments. GISP has also published guidelines and toolkits such as the Global Strategy on Invasive Alien Species and Invasive Alien Species: A Toolkit of Best Prevention and Management.

\section{Invasive Species Specialist Group of the International Union for the Conservation of Nature (IUCN-ISSG)}

The IUCN-ISSG ${ }^{265}$ provides information on invasive species that impact native biodiversity or ecosystems (their ecology, spread, management, and impacts) through the Global Invasive Species Database. IUCN-ISSG provides technical advice - for example if a government department is interested in importing species then IUCN-ISSG can give them advice. It also

\footnotetext{
261 The Micronesia Biosecurity Plan will rank invasive species, pathways, ports, and commodities for prioritisation. It will also make recommendations for required port facilities, staffing levels, staff trainings, technologies needed, best management practices, monitoring systems and rapid response capability for each Micronesian jurisdiction.

Phil Andreozzi, "Micronesia Biosecurity Plan (MBP)," September 11, 2009, http://www.doi.gov/NISC/global/international_cooperation/documents/MicronesianBiosecurityPlanonepager0909v2 .pdf.

262 Such as the David and Lucile Packard Foundation.

263 Including The Nature Conservancy, BirdLife International, and Conservation International.

264 Global Invasive Species Programme (GISP), n.d., http://www.gisp.org/.

265 IUCN/SSC Invasive Species Specialist Group (ISSG), "Invasive Species Specialist Group," n.d., http://www.issg.org/index.html.
} 
publishes publications on invasives such as "100 of the World's Worst Invasive Alien

Species", ${ }^{266}$ provides policy advice on invasive species to the IUCN, and was the coordinating agency for the Pacific Ant Prevention Plan - a regional strategy to prevent the entry, establishment, and spread of red imported fire ants and other invasive ant species. ${ }^{267}$

\section{Global Environment Facility (GEF)}

$\mathrm{GEF}^{268}$ is the one of the major international donors for global environment projects in the world. While the 14 Pacific Island countries only received USD \$84 million over the 15 years from 1991 to 2006, the GEF-Pacific Alliance for Sustainability (PAS) recently allocated USD $\$ 100$ million for environmental national and regional projects over the three years from 20072010. ${ }^{269}$ These projects are in five main areas: biodiversity, climate change adaptation, climate change mitigation, international waters, and persistent organic pollutants. Of the USD $\$ 37.7$ million allocated for biodiversity, $\$ 3.2$ million will be specifically for invasive species activities in ten Pacific island countries. ${ }^{270}$

\section{United Nations Environment Programme (UNEP)}

The UNEP ${ }^{271}$ provides leadership and is an authoritative source of expertise within the United Nations system on environmental issues. Its work includes assessing global, regional, and national environmental conditions and trends (for example it publishes the Pacific Environment Outlook ${ }^{272}$ ); developing international and national environmental instruments; facilitating the transfer of knowledge and technology for sustainable development; and hosting several environmental convention secretariats including the CBD Secretariat. The UNEP is also the implementing agency for the GEF-PAS Prevention, Control and Management of Invasive Alien Species in the Pacific Islands project.

\section{Critical Ecosystem Partnership Fund (CEPF)}

Another important source of funding for invasive species projects is the Critical Ecosystem Partnership Fund (CEPF), which is a partnership between the French Development Agency,

\footnotetext{
${ }^{266}$ Lowe et al., 100 of the World's Worse Invasive Alien Species: A selection from the Global Invasive Species Database.

${ }^{267}$ Pacific Invasive Ant Group (PIAG), Pacific Ant Prevention Plan.

268 Global Environment Facility (GEF), 2010, http://www.thegef.org/gef/home.

${ }^{269}$ Secretariat of the Pacific Regional Environment Programme (SPREP), 2009 Annual Report of the Secretariat of the Pacific Regional Environment Programme (SPREP) (Apia, Samoa: SPREP, 2010), 37, http://www.sprep.org/att/publication/000865_SPREP_ANNUAL_REPORT_2009.pdf.

${ }^{270}$ Cook Islands, FSM, Kiribati, Marshall Islands, Niue, PNG, Palau, Samoa, Tonga, and Vanuatu.

Global Environment Facility (GEF), "Regional - PAS Prevention, Control and Management of Invasive Alien Species in the Pacific Islands," 2007, http://www.gefonline.org/projectDetailsSQL.cfm?projID=3664.

${ }^{271}$ United Nations Environment Programme (UNEP), "Environment for Development," n.d., http://www.unep.org/.

272 Mclntyre, Pacific Environment Outlook.
} 
Conservation International, GEF, the Government of Japan, the John D. and Catherine T. MacArthur Foundation, and the World Bank. This funding source is only available to NGOs and regional organisations, not PICTs.

\subsection{National context}

National government and civil society actors ${ }^{273}$ are the implementers of invasive species management initiatives. Environmental, quarantine, and agricultural agencies all have important roles to play in invasive species management. However, several authors ${ }^{274}$ note that throughout the Pacific most environment departments often have limited human and financial resources to deal with the wide range of issues they face, including threats from invasive species. ${ }^{275}$ For example, Annette Lees notes that in Fiji government departments have far less capacity for conservation than NGOs in the country - there are about 45 government staff working on conservation outcomes for a total budget of USD $\$ 644,000$, compared to 103 people working in NGOs with a total budget of just under USD \$7.73 million. $^{276}$

All signatories to the CBD are required to develop National Biodiversity Strategy and Action Plans (NBSAPs), in which each country identifies their own priorities for conserving biodiversity. Collectively, these are the implementation plans for the Action Strategy for Nature Conservation and Protected Areas in the Pacific Island Region 2008-2012. A 2010 review $^{277}$ found that twelve Pacific Island countries ${ }^{278}$ have developed NBSAPs, and that invasive species management is included in almost all of them. Five (FSM, FSM, Marshall Islands, Palau, and Samoa) have also developed National Invasive Species Action Plans (NISAPs). Of the NBSAPs only the Federated States of Micronesia addressed at least some of the objectives in all nine thematic areas of the Guidelines for Invasive Species

\footnotetext{
${ }^{273}$ For example, the National Trust of Fiji, and the various local partners of Birdlife International (in the Cook Islands, Fiji, French Polynesia, New Caledonia, Palau, and Samoa).

${ }^{274}$ Pacific Invasives Initiative (PII), Invasive Species Management in the Pacific: A Review of National Plans and Current Activities (Auckland, New Zealand: Pacific Invasives Initiative, September 2010), 1.

McIntyre, Pacific Environment Outlook, 51.

275 These threats include mining, logging, land and marine pollution, safe drinking water and sanitation, climate change, natural disasters, land management, and energy.

${ }^{276}$ A. Lees and S. Siwatibau, "Strategies for Effective and Just Conservation: A Summary of the Austral Foundation's Review of Conservation in Fiji," Current Conservation 3, no. 3 (2009): 40.

${ }^{277}$ Pacific Invasives Initiative (PII), Invasive Species Management in the Pacific.

${ }^{278}$ Cook Islands, Fiji, FSM, Kiribati, Niue, Palau, PNG, Samoa, Solomon Islands, Tonga, and Vanuatu.
} 
Management in the Pacific. Only Samoa's NISAP addressed all nine thematic areas of the Guidelines. $^{279}$

\subsection{Summary}

In summary, despite having the best regional invasive species architecture in the world, ${ }^{280}$ there has not been much priority, or funding, given to invasive species issues in the Pacific. The master strategy for development priorities in the region, the Pacific Plan, only mentions them in terms of border biosecurity control, despite the potential for pre-existing invasive species to undermine development gains made in other areas. This is especially worrying given the emphasis placed on increasing trade, tourism, infrastructure, and potentially aquaculture projects - all of which are known pathways of invasive species. The three regional strategies discussed do mention invasive species, but do not mention how they might be managed or how the various projects that might be carried out under the various strategies might interact with one another.

In terms of the regional agencies and programmes the situation would appear to be under control. SPC is mandated to deal with invasive species in the agriculture, forestry, and aquaculture sectors, while SPREP works on invasive species of natural areas. PII provides support to site-based management projects, and PILN provides a regional network for information and skill sharing. International conventions cover various species (CBD, IPPC) and habitats (Ramsar), while GISP provides broad policy advice and IUCN-ISSG provides information on the invasive species themselves. However, there are only four employees in PII and two in SPREP (one is the coordinator for PILN and the other manages projects such as GEF-PAS). SPC currently does not have anyone employed on invasive species issues, which is an even bigger concern given that it coordinates the regional ant prevention programme (PAPP). Compared to the scale of the problem, there is also little funding available from government and multilateral sources - even the three year GEF-PAS project is only USD $\$ 7.5$ million $^{281}$ and is split over 10 countries.

\footnotetext{
${ }^{279}$ Common omissions included post-treatment restoration measures, pre-export control procedures, political support, best practice standards, baseline information gathering, monitoring, prioritisation, and research on priority invasive species.

Pacific Invasives Initiative (PII), Invasive Species Management in the Pacific, 20.

280 Stanley Burgiel, "National Invasive Species Council (NISC)," interview by Simon Lovatt, February 10, 2011.

${ }^{281}$ USD $\$ 3.2$ million is provided by GEF and the rest is co-financed.
} 


\section{The role of New Zealand actors in invasive species management}

Having looked at the international and regional context of invasive species management in the Pacific, this chapter looks at New Zealand's role in this area. New Zealand has a reputation as a world leader in biosecurity and eradication on small islands, and it is one of the major actors working on invasive species in the Pacific. There are four main New Zealand government agencies involved:

- Ministry of Foreign Affairs and Trade, through its International Development Group (IDG MFAT), manages the government's international aid and development programme;

- MAF Biosecurity New Zealand (MAFBNZ) is the division of the Ministry of Agriculture and Forestry charged with biosecurity issues; ${ }^{282}$

- Department of Conservation (DOC) has expertise in invasive species eradication projects; and

- Landcare Research is the country's foremost environmental research organisation specialising in terrestrial ecology.

The chapter begins by looking at IDG MFAT and asks how much aid is given, who receives the aid, and how its main development activities might impact invasive species issues. It then lists some of the main funding streams available for invasive species workers to access, and assesses IDG MFAT's environmental aid and leadership role on invasive species management in the Pacific. The chapter then looks at MAFBNZ, DOC, and Landcare Research and describes some of the ways these actors assist the Pacific.

The chapter concludes by assessing the New Zealand agencies motivations for assisting the Pacific, how much coordination there is between the agencies, and highlights the vital leadership role they have played in the region.

${ }^{282}$ MAF has been restructured as of 1 February 2011.

Ministry of Agriculture and Forestry (MAF), "Our Structure," January 14, 2011, http://www.maf.govt.nz/aboutmaf/our-organisation/our-structure. 


\subsection{International Development Group of the Ministry of Foreign Affairs and Trade (IDG MFAT)}

IDG MFAT, formerly known as the New Zealand Agency for International Development (NZAID), manages the vast majority of New Zealand's Official Development Assistance (ODA) programme ${ }^{283}$ and is the agency responsible for coordinating a whole-of-government effort on development cooperation. ${ }^{284}$ The 2009/2010 aid budget was approximately NZD $\$ 500$ million, of which over half went to the Pacific. While New Zealand is not necessarily a generous donor (in 2009 New Zealand's net ODA was $0.29 \%$ of $\mathrm{GNl}^{285}$, compared to the OECD ${ }^{286}$ average of $0.48 \%$, and less than half of the UN agreed target of $0.7 \%{ }^{287}$ ) it is seen as a very good donor. For example, the 2010 OECD Development Assistance Committee (OECD-DAC) peer review noted New Zealand was seen as being a respectful, open, and flexible partner who is appreciated as a neutral broker and valued for its knowledge and specific understanding of the unique Pacific context. ${ }^{288}$ Another report noted that "New Zealanders are seen as being more responsive, closer to the ground, less arrogant, less driven by multinational or national economic objectives". ${ }^{289}$

These sentiments were echoed in this research as well:

"[IDG MFAT] projects tend to be better focussed to peoples' needs. They actually look at resourcing environmental projects, which demonstrates they have an open mind - rather than building a giant wharf in a tiny lagoon with a shiny plaque." ${ }^{290}$

"[IDG MFAT] has an equal focus on livelihoods and biodiversity conservation. On small islands in particular, the two go hand in hand."291

"Countries develop their own invasive species management priorities - New Zealand's priority is to try and help them."292

\footnotetext{
${ }^{283}$ Other government departments also have some ODA expenditure in their budgets.

John Overton, "The aid industry in New Zealand," Journal of International Education in Business 1, no. 1 (February 2010): 28.

${ }^{284}$ New Zealand Agency for International Development (NZAID), Pacific Strategy 2007 - 2015, 5.

${ }^{285}$ Gross National Income.

${ }^{286}$ Organisation for Economic Co-operation and Development.

${ }^{287}$ Organisation for Economic Co-operation and Development (OECD), Table 1: Net Official Development Assistance In 2009 (OECD, April 14, 2010), http://www.oecd.org/dataoecd/17/9/44981892.pdf.

${ }^{288}$ OECD Development Assistance Committee (DAC), "New Zealand (2010) DAC Peer Review: Main Findings and Recommendations," 2010,

http://www.oecd.org/document/54/0,3746,en_21571361_37949547_46730038_1_1_1_1,00.html.

${ }^{289}$ Senate Foreign Affairs, Defence and Trade Committee, A Pacific engaged. Australia's relations with Papua New Guinea and the island states of the south-west Pacific (Chapter 9) (Canberra, Australia: Parliament of

Australia, August 12, 2003), 234, http://www.aph.gov.au/Senate/committee/fadt_ctte/completed_inquiries/2002-

04/png/report/c09.pdf.

${ }^{290}$ Keith Broome, "Island Eradication Advisory Group (IEAG), DOC," interview by Simon Lovatt, February 4, 2011.

${ }^{291}$ Saunders, "Landcare Research."
} 
The Pacific is the main focus of New Zealand's aid, ${ }^{293}$ and $\$ 253$ million was allocated to the region in 2009/2010. New Zealand's largest development engagements are with PNG, the Solomon Islands, and Vanuatu where the majority of Pacific people live and where development needs are greatest. ${ }^{294}$ New Zealand also supports Fiji, Kiribati, Samoa, Tonga, and Tuvalu, as well as fulfilling its constitutional obligations to support the Cook Islands, Niue, and Tokelau. ${ }^{295}$

IDG MFAT also provides untagged ${ }^{296}$ core budget funding to SPREP and SPC, which the agencies are then able to allocate based on the PICT members' priorities. This core budget support is extremely helpful because, as a number of interviewees noted, core funding is needed to employ enough staff to carry out the routine tasks that are necessary to allow the actual projects to go ahead.

"New Zealand is one of the biggest, helpful, and most reliable supporters of SPREP. We are quite fond of New Zealand as a donor - they have always been flexible and understanding, and permit SPREP and others to decide on priorities within budget and within fairly broad agreed guidelines."297

IDG MFAT has a core focus in supporting sustainable economic development in six main sectors: agriculture, fisheries, infrastructure, private industry, renewable energy, and tourism (as well as a continuing focus on health and education). All projects have environmental impact assessments build into the early stages of planning which are conducted by consultants and engineering firms. While these sectors are important for economic growth and poverty alleviation, some care must be taken to minimise the potential for them to be contributing factors to invasive species impacts. For example, developing infrastructure is seen as a way to achieve development goals in the region, especially in rural areas where there is expensive, nonexistent, or unreliable power supply, road access, shipping services, or water services. Thomson gives an example where poor infrastructure was a factor in the Tongan banana collapse: "the ships did not come, so fewer bananas were grown, so still

\footnotetext{
292 Boudjelas, "Pacific Invasives Initiative (PII)."

293 This is also a key region for New Zealand's foreign policy.

OECD Development Assistance Committee (DAC), "New Zealand (2010) DAC Peer Review: Main Findings and Recommendations."

${ }^{294}$ New Zealand also has a presence in the Solomon Islands as part of the Regional Assistance Mission to the Solomon Islands (RAMSI). Melanesia is also New Zealand's most significant trading area in the Pacific, involving almost half of New Zealand's exports and about $90 \%$ of Pacific imports.

Luamanuvao Laban, "Pacific Cooperation Foundation's Melanesia Symposium," September 30, 2008, http://www.beehive.govt.nz/speech/pacific-cooperation-foundation's-melanesia-symposium.

${ }^{295}$ New Zealand Aid Programme, "Pacific countries overview."

296 "Tagged" aid is where donors allocate money to be spent in specific areas, such as invasive species. "Tied" aid is a similar concept where donors put conditions on how the money will be spent such as requiring recipients to use consultants and service providers from the donor country. New Zealand does not tie its aid.

297 Alan Tye, "Secretariat of the Pacific Regional Environment Programme (SPREP)," interview by Simon Lovatt, January 21, 2011.
} 
fewer ships called". ${ }^{298}$ However, while international shipping is probably the most significant vector, invasive species can also spread within countries, and predators such as mongoose, rats, and cats can move into remote areas through logging roads. ${ }^{299}$ Ultimately these risks may be impossible to avoid, but it would be ideal if invasive species considerations were mainstreamed into the environmental assessments that are required for all IDG MFAT projects.

The Pacific Strategy 2007-2015 (which guides New Zealand's interaction with the region) is a potential avenue for addressing invasive species impacts. While invasive species are not mentioned specifically, climate change, access to sustainable fresh water, and the loss of biodiversity are identified as vulnerabilities in the region. ${ }^{300}$ All of these can be at least partly (and in some cases significantly) mitigated by managing invasive species.

\subsubsection{How does IDG MFAT assist with invasive species work in the Pacific?}

In addition to funding the regional organisations, IDG MFAT has several funding streams that New Zealand government agencies working on invasive species issues in the Pacific are able to access, including the Pacific Security Fund (PSF) ${ }^{301}$ and the State Sector Development Partnership Fund (SSDPF). All projects are required to have a strong partnership and buy-in from a counterpart agency in the Pacific, an assessment of complementarity with other donor initiatives, systems for monitoring and evaluation, and to be sustainable in the sense that long-term benefits continue after funding ceases. The SSDPF proposal form also specifically checks how projects align with partner country development plans.

\section{Pacific Security Fund (PSF)}

The PSF is an interagency annual pool of $\$ 3$ million available to New Zealand government departments and agencies to "undertake activities that will advance or protect New Zealand's security interests by reducing risks from threats arising in or operating through Pacific Island countries". ${ }^{302}$ In other words, the PSF is a fund for strengthening security in the Pacific, and can be accessed by agencies involved in areas such as biosecurity, aviation and maritime transport, fisheries, police, customs, immigration, and the Defence Force. MAFBNZ has

\footnotetext{
${ }^{298}$ S. Thomson, "Aid Directions for Depression Days," New Zealand International Review 34, no. 4 (2009): 18.

${ }^{299}$ A. Lees and S. Siwatibau, Review and analysis of Fiji's conservation sector (The Austral Foundation, November 2007), 18, http://australfoundation.org/Final report PDF Lees.pdf.

${ }^{300}$ New Zealand Agency for International Development (NZAID), Pacific Strategy 2007 - 2015, 24.

301 The PSF is managed by the Pacific Division of MFAT, not IDG MFAT.

${ }^{302}$ Ministry of Foreign Affairs and Trade (MFAT), "Pacific Security Fund," July 13, 2010, http://www.mfat.govt.nz/Foreign-Relations/Pacific/Regional-Security/0-pacsecfund.php.
} 
accessed the PSF to fund x-ray scanners in six Pacific countries, ${ }^{303}$ as well as an ant surveillance and training project under the PAPP. ${ }^{304}$ Interestingly the definition of security appears not to have been broadened to include human health, food security, or security from climate change; the interviewee from DOC had never even heard of the PSF.

\section{State Sector Development Partnership Fund (SSDPF)}

The SSDPF is a contestable funding source for state sector organisations to achieve sustainable development outcomes in their areas of expertise. ${ }^{305}$ The overarching goal for the SSDPF is to "contribute to prosperity, stability and reduction of poverty in partner countries by enhancing the conditions for broad-based sustainable economic development". Fundable activities include capacity building of skills and expertise; providing technical assistance; secondments; and strengthening institutional processes and systems. The main focus areas of the SSDPF are economic development (trade, market access, economic/fiscal/monetary policy); governance; law and judicial; health and education (clean water and sanitation); and vulnerability to natural disasters and climate change. DOC's work in Kiribati for the Phoenix Islands restoration project (see below) was funded through SSDPF.

\section{Other funding streams}

Two other funding sources that could be used for invasive species work are the Sustainable Development Fund and the Pacific Island Countries Participation Fund. The former is a funding source for New Zealand NGOs working in areas such as economic growth, health and education, clean water and sanitation, and protection from natural disasters; ${ }^{306}$ although I am unsure if any NGOs working on invasive species issues have accessed the fund. The latter is available to encourage attendance by Pacific Islanders at regional and international conferences. $^{307}$ This fund enabled six Pacific representatives of Birdlife International to attend the BirdLife World Conference and Global Partnership Meeting in Buenos Aires, Argentina in $2008 .^{308}$

\footnotetext{
303 The Cook Islands, Fiji, Niue, Samoa, Tonga, and Vanuatu.

${ }^{304}$ MAF Biosecurity New Zealand, "The battle for the Pacific: Keeping invasive ants at bay," April 30, 2008, http://www.biosecurity.govt.nz/publications/biosecurity-magazine/issue-77/pacific.

${ }^{305}$ New Zealand Aid Programme, "New Zealand State Sector Development Partnerships Fund," n.d., http://www.aid.govt.nz/what-we-do/dpf.html.

${ }^{306}$ New Zealand Aid Programme, "New Zealand NGO contestable funds," n.d., http://www.aid.govt.nz/what-wedo/nz-ngo-contestable-funds.html.

${ }^{307}$ New Zealand Aid Programme, "Pacific Island Countries Participation Fund," n.d., http://www.aid.govt.nz/pic/.

${ }^{308}$ BirdLife International, "BirdLife Pacific Work," 2011, http://www.birdlife.org/regional/pacific/work.html.
} 


\subsubsection{Assessing IDG MFAT's aid and leadership role}

As mentioned above, New Zealand gives over half of its aid to the Pacific. Storey et al. note that the reasons for this close-to-home strategy are historical, geographical, and strategic, but also reflect a pragmatic approach to using limited resources where they will have the greatest effect. ${ }^{309}$ Interestingly, a recent Parliament Select Committee report recommended increasing the proportion of assistance to the "Realm of New Zealand" entities: the Cook Islands, Niue, and Tokelau. ${ }^{310}$ These islands already have relatively high levels of development compared to the rest of the Pacific, although they have access to fewer services than other New Zealand citizens. It is not clear if this extra funding would come at the expense of other countries' aid or as part of a general rise in the IDG MFAT budget while other Pacific country allocations are kept at constant levels.

Environmental aid makes up a very small proportion ${ }^{311}$ of New Zealand's total ODA, so it is difficult to try and assess the aid in terms of a donor interest/recipient need model such as found in Lewis 2003. ${ }^{312}$ However, I believe that New Zealand's environmental aid is based on recipient need. New Zealand funds local environment issues such as clean water and sanitation, in addition to global issues such as biodiversity loss. Furthermore, the vast majority of New Zealand's environmental aid $\left(\sim 90 \%{ }^{313}\right)$ is given as untagged aid through multilateral institutions, further reducing the opportunity for a donor-interest model.

While invasive species are not a large part of IDG MFAT's budget, ${ }^{314}$ New Zealand is possibly unique in that it has a funding stream specifically for invasive species management. The New Zealand government, through IDG MFAT, has also played a critical leadership role in bringing the Pacific region together on the issue. ${ }^{315}$ It was instrumental in setting up the $\mathrm{Cll}$ in

\footnotetext{
${ }^{309}$ D. Storey, H. Bulloch, and J. Overton, "The poverty consensus: some limitations of the 'popular agenda'," Progress in Development Studies 5, no. 1 (2005): 38.

${ }^{310}$ Foreign Affairs, Defence and Trade Committee, Inquiry into New Zealand's relationships with South Pacific countries (I.4A) (Wellington, New Zealand: NZ Parliament, December 10, 2010), http://www.parliament.nz/NR/rdonlyres/2E654857-C58C-4710-B117-

D71118E6F5D5/175191/DBSCH_SCR_4945_InquiryintoNewZealandsrelationships.pdf.

${ }^{311}$ During the period 2005-2007 New Zealand's biodiversity-related aid was 3.5\% of total ODA, higher than the OECD average of $2.6 \%$. I am not certain if this figure includes funding for regional and multilateral organisations such as the GEF.

OECD Development Assistance Committee (DAC), Measuring aid targeting the objectives of the Rio Conventions (OECD, May 2009), 3, http://www.oecd.org/dataoecd/46/13/42819225.pdf.

312 Donor interest includes aid given to countries where the donor has economic (trade or foreign direct investment) or security interests, or similar political ideologies or post-colonial connections. Recipient need includes aid given to the poorest countries (generally sub-Saharan Africa).

${ }^{313}$ Robert L. Hicks et al., Greening Aid? Understanding the Environmental Impact of Development Assistance (New York: Oxford University Press, USA, 2008), 217.

${ }^{314}$ Funding for PII is $\$ 400,000$ out of a total budget of $\$ 500$ million.

${ }^{315}$ Boudjelas, "Pacific Invasives Initiative (PII)."
} 
2002, it is the main contributor to PII where it funds the salary of 2.6 FTEs, ${ }^{316}$ and it also funds the salary for one of the two invasive species officers at SPREP. New Zealand was also one of the main funders and the host of the 2010 Helping Islands Adapt Workshop, which involved 82 participants from 24 countries and territories, and 29 national, regional, and international organisations ${ }^{317}$ This workshop was a first step towards expanding the Cll into other regions, and a chance for professionals to meet to discuss invasive species management, share lessons learned, and expand links between the Caribbean, Europe/Mediterranean, the Coral Triangle, the Indian Ocean, and the Pacific. Unfortunately, while IDG MFAT provided funding for the event no staff attended, nor did individuals from any other state donor agencies. While it is understandable that donors can not attend every event that they fund, one interviewee believes it was a lost opportunity to educate individuals within the funding agencies about the importance of invasive species management, to raise their overall interest and confidence in the issue, and to build a history of contact between the donors to show them first-hand that they are not the only ones trying to address the issue.

\subsection{Ministry of Agriculture and Forestry Biosecurity New Zealand (MAFBNZ)}

MAF Biosecurity New Zealand is the division of MAF charged with leadership of the New Zealand's biosecurity system. ${ }^{318}$ It is responsible for coordinating all the various groups and agencies involved with invasive species issues in the country, and has the authority to create regulations (and impose fines), ${ }^{319}$ identify the priority issues and give guidance on how to deal with them. ${ }^{320}$

MAFBNZ's work in the Pacific is coordinated through the Pacific Activities Advisory Group (PAAG), which includes representatives from every area of MAFBNZ including border (airport, port), pest management, surveillance, and response teams. MAFBNZ's particular area of

\footnotetext{
${ }^{316}$ The CEPF and the David and Lucille Packard Foundation fund the other 1.4 FTE as well as project activities.

${ }^{317}$ Brian Sheppard, "Helping Islands Adapt," 2010, http://www.conference.co.nz/isw10.

${ }^{318}$ This system includes protecting primary production and trade, human health, and indigenous environments. MAF Biosecurity New Zealand, "History of the Strategy," October 16, 2008, http://www.biosecurity.govt.nz/biosec/sys/strategy/biostrategy/history.

${ }^{319}$ This power is granted under the New Zealand Biosecurity Act 1993.

320 This compares to the USA where the National Invasive Species Council (NISC) is an interagency mechanism that provides a facilitation and information role, but does not have any authority.
} 
expertise is in managing biosecurity risk and facilitating safe trade, and they give assistance to the Pacific. ${ }^{321}$ They have done a lot of capacity building including:

- training quarantine staff to identify insects and pests;

- running risk analysis workshops to enable countries to develop Import Health Standards; ${ }^{322}$

- developing a computer programme to help countries assess where gaps in their plant biosecurity might be, and suggests options to help fill those gaps;

- training port officials in the Sea Container Hygiene System; ${ }^{323}$ and

- $\quad$ helping the Pacific provide evidence needed to meet New Zealand's SPS standards.

In addition MAFBNZ has provided funding for IUCN-ISSG for the last two years.

\subsection{Department of Conservation (DOC)}

DOC has developed a lot of expertise implementing successful invasive species eradication projects. Much of this work has been carried out on small offshore islands, ${ }^{324}$ although DOC also controls invasive species on "mainland islands", where areas (which may also be isolated by fencing or geographical features) undergo intensive management of pests. ${ }^{325}$ DOC was established by the Conservation Act 1987 to conserve New Zealand's natural and historic heritage. As such, DOC does not have a mandate to undertake large or lengthy eradication projects outside the country, ${ }^{326}$ although they do provide advice and support to the Pacific on managing invasive species (especially advice on project management) through their Island Eradication Advisory Group (IEAG). Several interviewees praised DOC as being "very helpful, responsive, and generous - they provide lots of service free of charge" and "very forthcoming in how it helps - it is happy to share its expertise". Often DOC's assistance

\footnotetext{
${ }^{321}$ Much of this assistance is in plant and agricultural sectors, as there is not a lot of trade between the Pacific and New Zealand in animal products. Also note that MAFBNZ does not perform eradications (that is more of an area for PII or potentially even DOC to work on), but they do assist with surveillance activities.

322 These state the SPS requirements that have to be met before goods will be accepted into a country.

${ }^{323}$ This is a collaborative industry-government programme where sea containers are thoroughly cleaned and stored in special areas to reduce the possibility of carrying/transporting invasive species. This also helps lower costs for Pacific exporters as there are fewer inspections and fumigations required for compliant systems.

MAF Biosecurity New Zealand, "Pacific Programmes," September 7, 2010, http://www.biosecurity.govt.nz/biosec/pacific-portal/programmes.

${ }^{324}$ For example on Codfish Island, near Stewart Island, which is home to the critically endangered Kakapo.

${ }^{325}$ Because mainland islands are subject to continual reinvasion by pests they require much more ongoing commitment than actual islands.

Department of Conservation (DOC), "Mainland islands A-Z," n.d., http://www.doc.govt.nz/conservation/land-andfreshwater/land/mainland-islands-a-z/.

${ }^{326}$ DOC does a lot of international relations work such as assisting and advising Ministers with commitments under Multilateral Environment Agreements such as the CBD, as well as environmental provisions in Free Trade Agreements.
} 
is low key, such as an email or a phone call to project managers to discuss planning, methods, and options that can be used to get the job done. This technical support is extremely valuable for PICTs, as due to the small size of the environment ministries and the wide variety of issues they cover, it is very difficult for them to develop expertise in such a specialised area as invasive species management. DOC also assists with the development of PII training workshops.

One example where DOC has had a significant presence in the Pacific is its recent restoration work in the Phoenix Islands, Kiribati. The Phoenix Islands Protected Area (PIPA) is the largest marine protected area in the Pacific Ocean, and in 2010 was named a UNESCO World Heritage Site. The terrestrial ecosystem is also an important biodiversity area and so, using SSDPF funding, DOC partnered with the Kiribati Government Ministry for Environment, Lands and Agricultural Development to plan and implement a project to clear two islands rats and rabbits that were threatening the survival of several seabird colonies located on the atolls. A capacity building training workshop for officials from several government agencies ${ }^{327}$ was also held, and two Kiribati officials assisted with the actual eradication. Further eradication projects on additional islands in the Phoenix group are also planned with support from conservation NGOs, now that the Kiribati officials have demonstrated their commitment to managing invasive species. ${ }^{328}$ While DOC staff can only work outside the country for short periods due to their domestic mandate, they are very generous with that time, and often only charge for actual expenditure such as food, accommodation, and travel rather than salaries. During the Phoenix Island restoration project, all DOC salary time for the high level project management and administration was provided for free, and some staff even took annual leave to be part of the project.

\subsection{Landcare Research}

Landcare Research is a Crown Research Institute that is internationally recognised for its expertise in science-based natural resource management, particularly in terrestrial ecosystems. While its activities are focussed in New Zealand, Landcare Research also operates internationally, undertaking research and providing technical advice in Australia, South America, Asia, and elsewhere. ${ }^{329}$ In the Pacific they advise and assist with biodiversity conservation, as well as natural resource management more generally. They have a close working relationship with SPREP, and a Memorandum of Understanding with the USP which

\footnotetext{
${ }^{327}$ Wildlife Conservation Unit, Quarantine, Customs, Police, and Phoenix Island Administration.

${ }^{328}$ Nadine Koszler, "Restoring Biodiversity One Island At A Time," Currents, June 2010, 12.

${ }^{329}$ In comparison to DOC, Landcare Research is able to devote significant time and resources to projects outside of New Zealand.
} 
includes scientific support and the co-supervision of students from the university. Landcare Research has also set up a business called Invasive Species International (ISI) which advises on preparing invasive species strategies, undertaking feasibility studies, designing management projects, and post-project reviews.

While Landcare Research operates on a cost-recovery basis, it has also provided a lot of advice and assistance to PICTs (for example, through the PII) at no cost - partly because it believes it is the right thing to do, and also because its involvement through regional programmes can create opportunities for cost recovery. ${ }^{330}$

Landcare Research, in association with the University of Auckland (The Centre for Biodiversity and Biosecurity), and in collaboration with IUCN-ISSG, co-hosted the 2010 'Island Invasives: Eradication and Management' conference. ${ }^{331}$

In summary, New Zealand agencies assist with invasive species issues at a variety of levels. IDG MFAT provides budgetary support and funding to regional organisations and several PICTs, while DOC, MAFBNZ, and Landcare Research help with planning, implementation, and training for biosecurity and eradications in the Pacific.

All interviewees (from New Zealand and the region) said that New Zealand's expertise and involvement in invasive species issues in the Pacific was very beneficial for all concerned.

"New Zealand is seen as a world leader in invasive species management - especially in biosecurity and eradicating mammals from islands. The principles for biosecurity and eradications apply wherever you go. It's how you apply them that will be different."332

"New Zealand individuals tend to be understanding of the limitations of working in the Pacific and they are adaptable. DOC and MAF etc are good at getting local buy-in, and are by and large respectful of local sensitivities." ${ }^{333}$

\subsection{Assessing New Zealand's assistance}

Having introduced the main New Zealand agencies, this next section assesses their motivations for assisting the Pacific, how coherent their policies are, and describes the leadership role NZ has played.

\footnotetext{
${ }^{330}$ Saunders, "Landcare Research."

331 This conference concentrated on the technical aspects of invasive species management, whereas the Helping Islands Adapt workshop focused more on policy work and building networks between the various regions.

The Centre for Biodiversity and Biosecurity, "Island Invasives: Eradication and Management Conference," February 23, 2010, http://www.cbb.org.nz/conferences.asp.

332 Saunders, "Landcare Research."

${ }^{333}$ Tye, "Secretariat of the Pacific Regional Environment Programme (SPREP)."
} 


\subsubsection{Motivations of New Zealand agencies for assisting the Pacific}

All interviewees identified that invasive species have environmental, economic, and social impacts.

"The old thinking about invasive species is that they are just a conservation project for the greenies so you don't have to worry too much. The reality is quite different - it's an issue that cuts across all sectors - agriculture, tourism, health, biodiversity conservation, international trade."334

"Invasive species have environment, economic, and health impacts. New Zealand has its own domestic issues with invasives so we can empathise and have expertise in the area of invasive species management." 335

"New Zealanders get involved because they believe it is important, and that recovery and restoration is possible. There are also social and economic benefits to be had (e.g. stronger communities, nature tourism)." 336

While interviewees were partly motivated to act because of benefits to global biodiversity or New Zealand's own biosecurity, all interviewees (both in New Zealand and the region) believed that New Zealand's desire to help for the Pacific's sake was a major driver.

"Over the past five years New Zealand's ODA has been strongly focused on poverty reduction, health, and education. Environment work has focused on biodiversity conservation. Future work is likely to more strongly target economic and trade drivers." 337

"Sure there are pragmatic, political drivers. The best way to do biosecurity is in someone else's backyard, and with climate change and more subtropical fruits being grown in New Zealand, for example, we will be more susceptible to plant diseases which may come from Pacific. So there are good reasons why New Zealand has an interest in seeing biosecurity practises improved and consistently applied in the region. But New Zealand is also part of the Pacific, and we see ourselves as Pacific neighbours." 338

"MAF has a policy to push the risk offshore - if we protect the Pacific then we will protect ourselves. But New Zealand and Australia are also big brothers of the Pacific. We do need to do stuff there even if its not hugely beneficial to NZ...The bottom line is it has to be good for both of us, but there is a sense we should help out if we can. And we are happy to help if there is not a big budget blow out." 339

\footnotetext{
334 Broome, "Island Eradication Advisory Group (IEAG), DOC."

335 Paul Eastwood and Willy Morrell, "International Development Group (IDG) MFAT," interview by Simon Lovatt, January 21, 2011.

${ }^{336}$ Saunders, "Landcare Research."

${ }^{337}$ Eastwood and Morrell, "International Development Group (IDG) MFAT."

338 Saunders, "Landcare Research."

339 Sally Jennings, "International Policy, MAFBNZ," interview by Simon Lovatt, February 4, 2011.
} 
"New Zealand is doing it for the benefit of the countries, their people, and their biodiversity, but also not losing sight that there are also benefits for New Zealand - in terms of increased trade, improved access to markets in both New Zealand and the Pacific, and also an increased awareness of invasives species and biosecurity issues." 340

One of DOC's motivations is to learn and grow their own staff's capabilities to deal with the increasing variety of tropical species such as fire ants, copra blight, cane toads, and tree snakes.

"DOC tends to prioritise projects that are in the Pacific, or that DOC staff can learn from... There are always things to learn. The ecology in the tropics is quite different to temperate NZ in many respects, although there we do share some of the seabird species. So learning experiences and development opportunities for our staff are one of the things we look for." 341

This is not a negative thing either. Souad Boudjelas, programme manager of PII, believes that it is important that relationships are two-way, otherwise it becomes more of a donor/recipient relationship than a partnership.

Interestingly of all the interviewees (in both New Zealand and the region), only two mentioned moral reasons for assisting, possibly because they have had significant first-hand experience of the impacts of invasive species.

"Invasives are causing some of the most rapid changes in our lifetime in the Pacific, particularly on islands. It's only a matter of time until livelihoods as we know them are unsustainable in a growing number of situations." 342

"The Pacific has recognised invasive species in their NBSAPs as being significant threats to their biodiversity and livelihoods...they have asked for help so it's the right thing to do - after all they are our neighbours." 343

\subsubsection{How much collaboration is there between New Zealand agencies?}

There does not appear to be a large amount of collaboration between New Zealand agencies working on invasive species issues in the Pacific. For example, while DOC and MAFBNZ have complimentary expertise and do often work together on issues inside New Zealand, this is not the case in the Pacific. This is understandable given DOC's limited mandate to work outside the country, and the fact that biosecurity requests tend to come through SPC while eradication requests come through SPREP or PII. However, it would be preferable to see

\footnotetext{
340 Boudjelas, "Pacific Invasives Initiative (PII)."

${ }^{341}$ Broome, "Island Eradication Advisory Group (IEAG), DOC."

342 Saunders, "Landcare Research."

${ }^{343}$ Boudjelas, "Pacific Invasives Initiative (PII)."
} 
more interaction between DOC and MAFBNZ to ensure their policies and approaches are coherent and part of a whole-of-government approach. It should be relatively easy to instigate a coordination mechanism, because as one interviewee noted:

"New Zealand is a small country and the networks are pretty tight, so it's unusual for us not to know what others are doing, or hoping to do or not going to do, in the region. There is also a willingness to collaborate." 344

Some inter-agency collaboration is occurring, such as the joint effort by MAFBNZ, Landcare Research, SPC, and USP to provide technical advice to the U.S. Department of Defense's Micronesia Biosecurity Plan. Another example is the Pacific Border Security Working Group which includes officials from New Zealand Customs Service, Department of Labour, New Zealand Police, MAF, Department of Internal Affairs, and MFAT. This group has developed joint strategies and plans on how build capacity and develop border security in the region.

\subsection{Summary}

Ultimately invasive species in the Pacific only make up a small fraction of New Zealand's aid budget and it is not a core part of the other agencies' mandates either. However, despite this relatively small amount of focus, several interviewees (from NZ and the region) noted the vital leadership role that various New Zealand individuals and agencies have played in helping create regional networks, build local capacity, and enable project implementation. This leadership role is perhaps the most important aspect of New Zealand's assistance - as one interviewee pointed out, the amount of money a country provides is not always important, because if there is leadership that can bring other parties to the table that can leverage additional funds:

"New Zealand can do, and has done, a lot to show leadership, best practise, successful examples - it doesn't have to be strict policy and strategy. Leadership and nurture can go a long way."

\footnotetext{
344 Saunders, "Landcare Research."

${ }^{345}$ Burgiel, "National Invasive Species Council (NISC)."
} 


\section{Improving invasive species management}

Invasive species are one of the biggest threats to development and well-being in the Pacific. Their impacts are more immediate than climate change, and positive results are potentially easier to achieve than for climate change, natural disasters, or poverty alleviation. However, as mentioned earlier, invasive species are absent from some important regional documents such as the Pacific Plan; there are only six people working fulltime on the issues at a regional level; ${ }^{346}$ and there is limited funding - even for important programmes like the PAPP. ${ }^{347}$ Given the vast and wide ranging costs of invasive species to nearly every sector of the economy and society, why have invasive species not been not been given more emphasis in the Pacific?

This chapter investigates some reasons why invasive species issues have not been given more attention in the region. While the lack of information about the economic impacts of invasive species is a major reason, the weakness of environment ministries and the need for greater communication about invasive species and their affects are also contributing factors. The chapter concludes by offering some suggestions for the future, based on what interviewees would like to see happen for invasive species management in the region. This included more coordination between donors, long-term commitment to assistance by donors, and for New Zealand to continue to play its vital leadership role.

\subsection{Why have invasive species not been given more attention?}

One of the major reasons for the relative lack of regional attention is that the PICTs themselves are not prioritising invasive species management very highly, both in their domestic actions and in their dialogue with donors. Understandably, PICTs have other legitimate development priorities, and invasive species management can be an intensive, time-consuming, and potentially expensive process. However, there is little information available on the economic costs of invasive species in the Pacific which might otherwise alter decision makers' cost/benefit analyses. Also, environment ministries, who do recognise the importance of invasive species issues, tend to be small and stretched across a wide variety of

\footnotetext{
${ }^{346}$ Four of these people are in PII, and the other two are in SPREP.

${ }^{347}$ SPC has struggled to implement the PAPP due to funding problems.

Orapa to Lovatt, "Secretariat of the Pacific Community (SPC)."
} 
issues. It appears that invasive species workers at all levels could do more to raise awareness of the links between invasive species, livelihoods, food security, climate change, and other national concerns. If PICTs were to prioritise invasive species issues more highly, then presumably donors would fund more activities in the region. ${ }^{348}$

"The NZ view is less important in these things than the views of the Pacific countries themselves." 349

"The region and partner countries set their own goals and agendas. IDG MFAT does not have specific goals for its invasive species funding, although it has traditionally focused on biodiversity conservation. Future work is likely to be linked more strongly to agricultural production, trade, and biosecurity." 350

\subsubsection{Lack of economic information}

The lack of information on the economic impact of invasive species is potentially a major reason why PICTs are not prioritising their management highly. Countries such as New Zealand have very good information on the value of the environment and its ecosystem services. ${ }^{351}$ A 1997 study found that biodiversity contributed well over twice the value of New Zealand's GDP, ${ }^{352}$ and the environment is an essential component of sectors like the tourism industry, which makes up around $10 \%$ of the economy. There is also information available about the current economic costs of invasive species ${ }^{353}$ as well as the potential damage that new pests and diseases could have. For example, a foot and mouth disease outbreak could cost the economy NZD $\$ 10$ billion over two years, put thousands of jobs at risk, and take years to recover from. ${ }^{354}$ Invasive species could also threaten New Zealand's agriculture and forestry industries which are worth billions of dollars. In recognition of these costs and benefits New Zealand spends around $\$ 500$ million on biosecurity each year. ${ }^{355}$

\footnotetext{
${ }^{348}$ Many donors, including New Zealand, have endorsed the Paris Declaration on Aid Effectiveness, which obliges donors to align with recipient priorities and to ensure recipient ownership of programmes.

New Zealand Agency for International Development (NZAID), Pacific Strategy 2007 - 2015, 32-33.

${ }^{349}$ Broome, "Island Eradication Advisory Group (IEAG), DOC."

${ }^{350}$ Eastwood and Morrell, "International Development Group (IDG) MFAT."

${ }^{351}$ For instance, a single conservation area in Otago provides water services at no charge for hydroelectricity, urban water supplies, and farmland irrigation that would otherwise cost NZD \$136million to supply that water from elsewhere.

The Economics of Ecosystems and Biodiversity (TEEB), TEEB for National and International Policy Makers. Summary: Responding to the Value of Nature, 2009, 19, http://www.teebweb.org/Portals/25/Documents/TEEB for National Policy Makers/TEEB for Policy exec English.pdf.

352 New Zealand Biodiversity, "Why we value biodiversity," n.d., https://www.biodiversity.govt.nz/picture/biodiversity/why.html.

353 Giera and Bell, Economic Costs of Pests to New Zealand.

354 MAF Biosecurity New Zealand, “The Biosecurity System," December 17, 2010, http://www.biosecurity.govt.nz/biosec/sys.

${ }^{355}$ MAF Biosecurity New Zealand, "About Us - Our Organisation," November 21, 2008, http://www.biosecurity.govt.nz/biosec/org.
} 
In comparison, in the Pacific there is very little information available on the economic costs of invasive species, ${ }^{356}$ and even less on their social, cultural, and environmental costs. Several interviewees noted this:

“Most decision makers and politicians aren't aware of the economic impacts of invasive species. It's hard to make good decisions about invasive species management when economic information is not available." 357

"We are demand-driven, but there doesn't appear to be a high demand for tackling Pacific invasive species. Many PICTs have other priorities (weeds vs vaccinations). Plus many PICTs don't fully appreciate the potential economic and environmental impacts of invasive species." 358

"Yes [NZAID] is demand driven, but the islands don't know what they don't know - and they can't ask if they don't know. New Zealand has lots of information and technology. If the Pacific knew what we know it would make a difference." ${ }^{359}$

One example where research is occurring is a project between Landcare Research, PII, and other partners to undertake a preliminary evaluation of the economic implications of invasive species in the Pacific. However, if PICT decision makers are to be enabled to make better cost/benefit calculations about invasive species management then, in this author's opinion, donors should provide funding for more comprehensive assessments.

\subsubsection{Weak environment ministries}

Environment ministries in PICTs are prioritising invasive species issues and requesting assistance. Invasive species are part of the regionally-agreed SPREP Strategic Plan 2011$2015,{ }^{360}$ and the various country NBSAPs and NISAPs explicitly refer to them. For New Caledonia, the only country that could be contacted to participate in this research, invasive species are the third-equal priority for donor assistance, coming after health and education but equal with climate change because of the interlinked effects. ${ }^{361}$ Kiribati, a country which is extremely vulnerable to climate change and thus has very good reasons not to be focussing on invasive species, has a strong commitment to managing them. ${ }^{362}$ There have

\footnotetext{
356 The cost of taro blight in Samoa is one of the few available examples. The disease is estimated to have cost USD $\$ 40$ million and taken the industry 20 years to recover from.

Secretariat of the Pacific Regional Environment Programme (SPREP), "Factsheet: Invasive Species."

357 Saunders, "Landcare Research."

${ }^{358}$ Eastwood and Morrell, "International Development Group (IDG) MFAT."

359 Jennings, "International Policy, MAFBNZ."

${ }^{360}$ Secretariat of the Pacific Regional Environment Programme (SPREP), Secretariat of the Pacific Regional Environment Programme (SPREP) Strategic Plan : 2011-2015 (Apia, Samoa: SPREP, 2011), 23, http://www.sprep.org/att/publication/000911_SPREP_Strategicplan_2011_2015.pdf.

${ }^{361}$ Lafoy, "Government of New Caledonia representative."

362 This is possibly because tourism makes up a significant proportion of their national economy.
} 
also recently been two strong messages communicated to New Zealand and other donors that invasive species are one of the top priorities in the region. ${ }^{363}$ However, on the whole, environment ministries in the Pacific are often small, weak, and stretched across a wide range of issues including mining, logging, land and marine pollution, safe drinking water and sanitation, climate change, natural disasters, land management, and energy. ${ }^{364}$ This makes it difficult for PICTs to properly address invasive species.

"Some of these countries are very small. So having an environment ministry with three people might not be undervaluing conservation."365

"Unfortunately in the Pacific it does come down to individuals and it does come down to personalities, because it's such a small field. Their departments might only be made up of one or two people (New Zealand has hundreds) so if they don't either have the training or the interest then it's very hard for the programmes which have a vested interest for New Zealand to continue." 366

"You can't always assume that the government and communities have good links. The environment ministries may only have a few people and they might be tied down with lots of bureaucracy, reporting requirements regarding international or regional agreements and briefing the minister/attending meetings - rather than getting out to the various islands. Even if they have time to get out into the community, often the ministries do not have the budget to do so." ${ }^{367}$

\subsubsection{Communication issues}

Several interviewees also noted that there appears to be a lack of communication between environment ministries and the foreign ministries in PICTs. Although environment departments rate invasive species as one of their top priority issues, ${ }^{368}$ in bilateral discussions with donors, health and education are of higher priority for the Pacific. If this situation is to change, and PICTs are to recognise invasive species as a national security issue as they have done with climate change, ${ }^{369}$ then people working on invasive species issues need to

\footnotetext{
${ }^{363}$ One was from the April 2010 Helping Islands Adapt workshop, and the other was at the annual SPREP member country meeting in September 2010, where all countries supported a working paper tabled by New Caledonia saying that more emphasis needs to be placed on invasive species management.

New Caledonia, Agenda Item 11.1: Mainstreaming invasive species and biodiversity, Working Paper (Madang, Papua New Guinea: SPREP, June 14, 2010), http://www.sprep.org/2010SM21/pdfs/eng/Officials/WP_11_1_NC paper_Mainstreaming Invasive species and biodiversity.pdf.

${ }^{364}$ McIntyre, Pacific Environment Outlook, 1-4.

365 Saunders, "Landcare Research."

366 Jennings, "International Policy, MAFBNZ."

${ }^{367}$ Kevin Clark, interview by Simon Lovatt, January 31, 2011.

${ }^{368}$ Boudjelas, "Pacific Invasives Initiative (PII)."

Tye, "Secretariat of the Pacific Regional Environment Programme (SPREP)."

${ }^{369}$ Invasive species and climate change both impact food security, water security, human health and diseases, subsistence crops and coral reef fisheries, as well as having social impacts. However, currently invasive species have not been recognised as a national security issue to the same extent as climate change.
} 
make the links between invasive species, livelihoods, food security, water security, health, and climate change clearer to officials in both PICTs and donor countries.

"Our job as invasive species stakeholders is to raise awareness that it is not just a conservation issue but it is a livelihood issue. We need to make the links between livelihoods, security, and invasive species."

"Politicians and donors see invasive species that affect livelihoods and economy as a priority. But invasive species that affect ecosystems also affect livelihoods and economies, particularly on islands." ${ }^{371}$

"Some countries have a holistic view, while others are caught by the structure of their governments which often separate these things into different departments. Both in New Zealand and in other countries the 'silo' effect of giving a government department a specific mandate and severely constraining their resources, drives everyone to focus only on their own core business without seeing the bigger picture."372

"Most New Zealand politicians would probably not be aware that invasive species in the Pacific are more than just an environmental concern." 373

\subsection{Some suggestions for the future}

The final section of this thesis offers some suggestions for invasive species management in the future, based on what interviewees said they would like to see occur with New Zealand's assistance to the Pacific, and for the region more generally.

\subsubsection{Ideas for New Zealand}

Although all interviewees praised New Zealand's assistance with invasive species management in the Pacific, many felt that, if possible, New Zealand should increase its engagement and assistance on these issues.

Some interviewees believed that IDG MFAT should continue to fund PII, saying that if funding were cut it would be "a huge setback for invasive species management in the region", and that if similar amounts of funding were to be given to regional organisations instead then invasive species work would not happen to anywhere near the same extent. Several interviewees also said that it would be ideal if MFAT staff communicated with a wider variety of stakeholders in the recipient countries, and even raised invasive species issues during bilateral aid discussions: aid is a two-way negotiation, not IDG MFAT just passively receiving

\footnotetext{
${ }^{370}$ Pagad, "Invasive Species Specialist Group (IUCN-ISSG)."

371 Saunders, "Landcare Research."

372 Broome, "Island Eradication Advisory Group (IEAG), DOC."

${ }^{373}$ Kennedy Graham to Simon Lovatt, "MP, Green Party of Aotearoa New Zealand," March 1, 2011.
} 
requests. Finally, many interviewees expressed their desire for New Zealand to continue its leadership on invasive species management in the region.

\subsubsection{Coordination with other donors}

Many participants also recognised the desirability of greater coordination with other donors in the region. This is important to avoid duplication of efforts so that the relatively small amount of funding that is available is put to the best possible use.

"Getting the donor countries working together would be a good thing. We are working much better with Australia than we have previously; but we need to work closely with all donor countries so we don't continually do the same thing. Because often we'll go in and spend some money doing risk assessment workshops, and then for example the European Union will go in and do some as well." 374

Currently, there does not appear to be much coordination between the various donors apart from their membership in the CROP agencies. Australia and New Zealand have increasing amounts of contact on biosecurity issues in the Pacific, ${ }^{375}$ and New Zealand also has contact with several American government agencies through the PIP network. ${ }^{376}$ However, if invasive species issues are to be managed more effectively then donors need to collaborate even more than happens presently. One avenue to achieve this might be to extend the membership of PIP, which is the lead group responsible for coordinating action on invasive species management in the region. There are currently 26 members of PIP, but it would be beneficial to include donor (and technical assistance) agencies from Australia, France, UK, EU, Japan, and China, as well as MAFBNZ and private donors such as the David and Lucille Packard Foundation.

Another potential opportunity for collaboration is through the recently-created French Great Observatory of South Pacific Environment and Land \& Ocean Biodiversity (Grand Observatoire de l'environnement et de la biodiversité terrestre et marine du Pacifique Sud) which coordinates the research agencies working in the French Territories. ${ }^{377}$

\footnotetext{
374 Jennings, "International Policy, MAFBNZ."

375 lbid.

${ }^{376}$ These are the USDA Forest Service, US Department of State, and the US National Invasive Species Council. The New Zealand government members of PIP are IDG-MFAT, DOC, and Landcare Research.

377 University of French Polynesia, "Creation of the Great Observatory of South Pacific Environment and Land \& Ocean Biodiversity," December 14, 2010, http://webdevel.upf.pf/Creation-of-the-Great-Observatory.html?lang=en.
} 
Regional trade agreements offer a further avenue to broaden and deepen cooperation on invasive species management. ${ }^{378}$ One interviewee pointed out that the Trans Pacific Partnership (TPP) free trade agreement negotiations represent such an opportunity:

"The TPP includes a range of interesting countries, such as New Zealand, Australia, and the USA who have lots of expertise in invasive species management; and others such as Chile, Vietnam, Malaysia and Singapore who are very interested in developing their own invasive species systems. The TPP could be a unique forum to exchange information, expertise, and best practise and look at the issue in the context of a trade agreement. After all, trade is critically linked to the movement of invasive species." 379

If invasive species were successfully incorporated into the TPP and the TPP was used as a forum for discussion and collaboration, then it could provide a template to expand the incorporation of countries into invasive species management networks even further, for example through the Asia Pacific Economic Cooperation (APEC) countries. After all, managing invasive species transported by trade will become increasingly important as global economies become more interdependent.

\subsubsection{Need for long-term commitment}

Most interviewees commented that working on invasive species issues involves a significant amount of time, both in terms of implementing projects and seeing results, as well as building capacity within islands and the region.

They stressed that there needs to be continuity of engagement and funding by donors and technical assistance agencies if lasting results are to be achieved in the Pacific.

"It's very hard to get social outcomes right, especially at the start who knows what's realistic, or what the outcomes will be. The only people who can sustain outcomes are local people - and these will evolve." 380

"Building relations and trust takes a while - they need to know that you have their interests at heart and that you do want to help them get their product into New Zealand or see that kids don't suffer from ants. Pacific Islanders are friendly, very welcoming and they treat you very well. But when you are dealing with their livelihood, or their

\footnotetext{
${ }^{378}$ Burgiel et al. note that ideally regional trade agreements would have invasive species prevention measures that are consistent with the WTO SPS Agreement, take a conservative approach, and place the burden of proof on exporters. At a minimum, countries should work on establishing basic communication structures, such as learning networks, eventually aiming for development of guidelines and approaches for joint regulation of priority pathways for introductions of invasive alien species.

Stas Burgiel et al., Invasive Alien Species and Trade: Integrating Prevention Measures and International Trade Rules (Washington D.C.: Center for International Environmental Law (CIEL) and Defenders of Wildlife, January 2006), 42-49, http://cleantrade.typepad.com/clean_trade/files/invasives_trade_paper_0106.pdf.

${ }^{379}$ Burgiel, "National Invasive Species Council (NISC)."

380 Saunders, "Landcare Research."
} 
community - you need to prove and show them you have their best interests at heart. If you do that you'll have buy-in for your projects. Otherwise the project won't be sustainable."381

While it may not be suitable to build invasive species management expertise in every PICT, all interviewees believed that, as much as possible, skills should continue to be transferred to the region. Although some stated their concern that trained personnel might not pass their new skills and information onto their co-workers when they move on, others felt that donors should expect some level of attrition, and also noted that most people still remained in the region.

“Developing capacity is even about making people aware. It doesn't matter if someone leaves after a few years. They might still be the Pacific, and they would have spoken about the issues at home and with colleagues - and there is value in that." 382

"One view is that if you let enough marked fish go in the pool then eventually you'll have a good chance of catching one with a mark on it. Reaching a critical mass of expertise in an organisation is a challenge for all of us; how l've observed this challenge being met in Pacific countries is to share resources and expertise across countries through organisations like SPC, the Pacific Roundtable, SPREP, PII etc." ${ }^{383}$

\subsubsection{Need for post-export control}

Finally, all countries, including New Zealand, should ensure that adequate pre-export control occurs, as recommended in the Guidelines for Invasive Species Management in the Pacific. $^{384}$ As Meyerson and Mooney note, it is far more effective to control or prevent the spread of invasive species at their source than try to prevent their importation. ${ }^{385}$ Currently, the burden is on the importing country to manage their border and so exporters only fumigate if they are required to. For example, although the New Zealand Defence Force cleans all equipment and vehicles before returning from overseas deployments, when operations leave New Zealand they are only cleaned and inspected to the standard required by receiving countries, if a standard exists. ${ }^{386}$ This may not always be appropriate in countries such as the Pacific that may have adequate capacity or information to deal with potential invasive species from New Zealand. ${ }^{387}$

\footnotetext{
381 Jennings, "International Policy, MAFBNZ."

382 Pagad, "Invasive Species Specialist Group (IUCN-ISSG)."

${ }^{383}$ Broome, "Island Eradication Advisory Group (IEAG), DOC."

${ }^{384}$ Tye, Guidelines for invasive species management in the Pacific, 17.

${ }^{385}$ Meyerson and Mooney, "Invasive alien species in an era of globalization," 207.

${ }^{386}$ Gary Pennefather to Simon Lovatt, "New Zealand Defence Force (NZDF)," February 11, 2011.

${ }^{387}$ For example, the pohutukawa is considered an invasive species outside New Zealand. Graham Harris, "Our native plant invaders," Journal of the Royal New Zealand Institute of Horticulture 5, no. 1 (2002): 6-7.
} 


\subsection{Conclusion}

Managing invasive species can be a time-consuming, complex, and even expensive task. However it is important that management occurs and capacity is built in the Pacific, in order to minimise the wide-ranging economic, environmental, and social costs that invasive species can impose on islands that already have other development issues to contend with. Assisting islands can also be a positive thing for donor countries, as it reduces risks to their biosecurity or even offers opportunities for learning.

New Zealand has played a critical leadership role in helping to bring the region together and raising awareness of invasive species issues. New Zealand agencies have assisted with funding, capacity building, and even project implementation, and all interviewees have been very appreciative of their efforts.

Yet despite having the best regional invasive species architecture in the world, much work remains to be done in the Pacific. All donors must have a long term commitment to supporting Pacific Island countries and territories, as well as increase coordination amongst themselves, if we are to turn the geographic isolation of the Pacific into an advantage to prevent the spread of invasive species. 


\section{References}

$100 \%$ Pure New Zealand. "Smelly NZ birds may need odour protection > New Zealand," September 24, 2010. http://www.newzealand.com/travel/media/pressreleases/2010/9/nature_smelly-nz-birds-may-need-odour-protection_pressrelease.cfm.

Abbott, K. L. "Supercolonies of the invasive yellow crazy ant, Anoplolepis gracilipes, on an oceanic island: forager activity patterns, density and biomass." Insectes Sociaux 52 , no. 3 (2005): 266-273.

Andreozzi, Phil. "Micronesia Biosecurity Plan (MBP)," September 11, 2009. http://www.doi.gov/NISC/global/international_cooperation/documents/MicronesianBios ecurityPlanonepager0909v2.pdf.

Asia-Pacific Forest Invasive Species Network (APFISN). "Invasives: Newsletter of the," February 2007. http://www.fs.fed.us/global/topic/invasives/feb2007.pdf.

Bell, Andrew, Simon Phillips, Eugene Georgiades, and Daneil Kluza. Risk Analysis: Vessel Biofouling. Wellington, New Zealand: Ministry of Agriculture and Forestry, February 15, 2011. http://www.biosecurity.govt.nz/files/regs/imports/risk/vessel-biofouling-riskanalysis-0211.pdf.

BirdLife International. "BirdLife Pacific Work," 2011. http://www.birdlife.org/regional/pacific/work.html.

Boudjelas, Souad. "Meeting the Invasive Species Challenge in the Pacific Region." Auckland, New Zealand, 2010. www.conference.co.nz/files/docs/pacific presentation for is workshop april 2010 final.pdf.

___. "Pacific Invasives Initiative (PII)." Interview by Simon Lovatt, January 26, 2011.

Broome, Keith. "Island Eradication Advisory Group (IEAG), DOC." Interview by Simon Lovatt, February 4, 2011.

Burgiel, S. W, and A. A Muir. Invasive Species, Climate Change and Ecosystem-Based Adaptation: Addressing Multiple Drivers of Global Change. Washington, DC, USA, and Nairobi, Kenya: Global Invasive Species Programme (GISP), September 2010.

Burgiel, Stanley. "National Invasive Species Council (NISC)." Interview by Simon Lovatt, February 10, 2011.

Burgiel, Stas, Greg Foote, Marcos Orellana, and Anne Perrault. Invasive Alien Species and Trade: Integrating Prevention Measures and International Trade Rules. Washington

D.C.: Center for International Environmental Law (CIEL) and Defenders of Wildlife, January 2006.

http://cleantrade.typepad.com/clean_trade/files/invasives_trade_paper_0106.pdf.

CBD Executive Secretary. Invasive Alien Species, Case-studies and Country Comments on Invasive Alien Species. Subsidiary Body on Scientific, Technical and Technological Advice. Montreal: Convention on Biological Diversity, 2001. http://www.issg.org/cii/Electronic references/pii/CBD_IAS case studies.pdf.

Pilot Assessments: The Ecological and Socio-economic Impact of Invasive Alien Species on Island Ecosystems. Subsidiary Body on Scientific, Technical and Technological Advice. Montreal: Convention on Biological Diversity, 2003. http://www.issg.org/cii/Electronic references/pii/CBD_IAS island impacts.doc. 
CBD Secretariat. Global Biodiversity Outlook 3. Montreal: Convention on Biological Diversity, 2010. http://www.cbd.int/doc/publications/gbo/gbo3-final-en.pdf.

Clark, Kevin. Interview by Simon Lovatt, January 31, 2011.

Coates, B. "Getting serious about achieving the Millennium Development Goals in the Pacific: Strengthening Economic Development." Policy Quarterly 5, no. 3 (August 2009): 2837.

Convention on Biological Diversity, 2011. http://www.cbd.int/.

Convention on Biological Diversity (CBD). "Article 8. In-situ Conservation," March 30, 2007. http://www.cbd.int/convention/articles/?a=cbd-08.

—_. "List of Parties," n.d. http://www.cbd.int/convention/parties/list/.

Crosby, M. P., G. Brighouse, and M. Pichon. "Priorities and strategies for addressing natural and anthropogenic threats to coral reefs in Pacific Island Nations." Ocean \& Coastal Management 45, no. 2 (2002): 121-137.

Department of Conservation (DOC). "Ferrets," n.d. http://www.doc.govt.nz/conservation/threats-and-impacts/animal-pests/animal-pestsa-z/ferrets/.

—_ "Mainland islands A-Z," n.d. http://www.doc.govt.nz/conservation/land-andfreshwater/land/mainland-islands-a-z/.

___ "Mana Island Scientific Reserve," n.d. http://www.doc.govt.nz/parks-andrecreation/places-to-visit/wellington-kapiti/kapiti/mana-island-scientificreserve/features/conservation/.

___ "Rainbow lorikeet," n.d. http://www.doc.govt.nz/conservation/threats-andimpacts/animal-pests/animal-pests-a-z/rainbow-lorikeet/.

___ "Rats," n.d. http://www.doc.govt.nz/conservation/threats-and-impacts/animalpests/animal-pests-a-z/rats/.

__ . "The threat of Possums," n.d. http://www.doc.govt.nz/conservation/threats-andimpacts/animal-pests/animal-pests-a-z/possums/the-threat/.

—_ "Weasels," n.d. http://www.doc.govt.nz/conservation/threats-and-impacts/animalpests/animal-pests-a-z/weasels/.

—_. "What is biodiversity," n.d. http://www.doc.govt.nz/getting-involved/events-andawards/international-year-of-biodiversity/what-is-biodiversity/.

Department of Water Affairs. "Welcome to the Working For Water Webpage," n.d. http://www.dwaf.gov.za/wfw/.

Doyle, Alister. "Invasive Species Lie in Wait, Strike After Decades." ABC News, December 20, 2010. http://abcnews.go.com/Technology/wireStory?id=12442736\&page=1.

Eastwood, Paul, and Willy Morrell. "International Development Group (IDG) MFAT." Interview by Simon Lovatt, January 21, 2011.

Environment Canterbury. "Plant Pest: Chilean Needle Grass," n.d. http://www.ecan.govt.nz/publications/General/ChileanNeedleGrassFlyerA.pdf.

Foreign Affairs, Defence and Trade Committee. Inquiry into New Zealand's relationships with South Pacific countries (I.4A). Wellington, New Zealand: NZ Parliament, December 10, 2010. http://www.parliament.nz/NR/rdonlyres/2E654857-C58C-4710-B117D71118E6F5D5/175191/DBSCH_SCR_4945_InquiryintoNewZealandsrelationships.p df. 
Giera, Nick, and Brian Bell. Economic Costs of Pests to New Zealand. Ministry of Agriculture and Forestry, September 2009. http://www.biosecurity.govt.nz/files/pests/survmgmt/economic-costs-of-pests-to-new-zealand.pdf.

Global Environment Facility (GEF), 2010. http://www.thegef.org/gef/home.

. "GEF-PAS Project Identification Form," 2007.

http://www.gefonline.org/ProjectDocs/Pacific Alliance for Sustainability (PAS)/Regional

- Prevention, Control -- Invasive Alien - GEF ID 3664/10-17-08 PIF document revised ID3664.doc.

_- "Regional - PAS Prevention, Control and Management of Invasive Alien Species in the Pacific Islands," 2007.

http://www.gefonline.org/projectDetailsSQL.cfm?projID=3664.

Global Invasive Species Programme (GISP), n.d. http://www.gisp.org/.

. Biofuel Crops and the use of Non-native Species: Mitigating the Risks of Invasion.

Nairobi, Kenya: Global Invasive Species Programme (GISP), May 2008.

http://www.sprep.org/att/IRC/eCOPIES/Global/155.pdf.

___ "Ecology and Management of Invasive Alien Species: Management," 2008.

http://www.gisp.org/ecology/strategies.asp.

__ . "GISP Phase I: Human Dimensions of Invasive Species," 2008.

http://www.gisp.org/about/phase1/human.asp.

__ Invasive Species and Poverty: Exploring the Links. Cape Town, South Africa: Global Invasive Species Programme (GISP), 2007.

http://www.gisp.org/publications/reports/invasivesandpoverty.pdf.

Goddard, Jacqui. "Lionfish devastate Florida's native shoals." The Times, October 20, 2008. http://www.timesonline.co.uk/tol/news/environment/article4974396.ece.

Graham, Kennedy. Letter to Simon Lovatt. "MP, Green Party of Aotearoa New Zealand," March 1, 2011.

Harris, Graham. "Our native plant invaders." Journal of the Royal New Zealand Institute of Horticulture 5, no. 1 (2002): 6-8.

"Helping Islands Adapt - Concept Paper," April 2010.

http://www.conference.co.nz/files/docs/info doc 1 docdm-552471 concept paper v10 high res.pdf.

Hicks, Robert L., Bradley C. Parks, J. Timmons Roberts, and Michael J. Tierney. Greening Aid? Understanding the Environmental Impact of Development Assistance. New York: Oxford University Press, USA, 2008.

Hulme, P. E. "Trade, transport and trouble: managing invasive species pathways in an era of globalization." Journal of Applied Ecology 46, no. 1 (2009): 10-18.

Hunnam, Peter. Lessons in Conservation for People and Projects in the Pacific Islands Region. New York: United Nations Development Programme (UNDP), 2002. www.undp.org.ws/Portals/12/pdf/lessons.pdf.

Hussey, Genevieve. "Fire Ant Battle." Radio Australia, June 11, 2007. http://www.abc.net.au/ra/innovations/stories/s1928616.htm.

International Fund for Agricultural Development (IFAD). Climate Change Impacts - Pacific Islands -. International Fund for Agricultural Development, April 2009. http://www.ifad.org/events/apr09/impact/islands.pdf.

International Maritime Organization (IMO), 2010. http://www.imo.org/Pages/home.aspx. 
—_. "Introduction to IMO," 2010. http://www.imo.org/About/Pages/Default.aspx.

—_. "Sub-Committee on Bulk Liquids and Gases (BLG), 14th session: 8 to 12 February 2010," February 2010.

http://www.imo.org/MediaCentre/MeetingSummaries/BLG/Pages/BLG-14th-

Session.aspx.

International Plant Protection Convention (IPPC), n.d. https://www.ippc.int/.

__. "Convention, model instruments and related information," January 21, 2010. https://www.ippc.int/index.php?id=convention\&no_cache=1\&L=0.

IUCN/SSC Invasive Species Specialist Group (ISSG). "Invasive Species Specialist Group," n.d. http://www.issg.org/index.html.

_- IUCN guidelines for the prevention of biodiversity loss caused by alien invasive species. Gland Switzerland,: International Union for Conservation of Nature (IUCN), February 2000.

http://intranet.iucn.org/webfiles/doc/SSC/SSCwebsite/Policy_statements/IUCN_Guidel ines_for_the_Prevention_of_Biodiversity_Loss_caused_by_Alien_Invasive_Species.p df.

Jennings, Sally. "International Policy, MAFBNZ." Interview by Simon Lovatt, February 4, 2011.

Koszler, Nadine. "Restoring Biodiversity One Island At A Time." Currents, June 2010.

Laban, Luamanuvao. "Pacific Cooperation Foundation's Melanesia Symposium," September 30, 2008. http://www.beehive.govt.nz/speech/pacific-cooperation-foundation'smelanesia-symposium.

Lafoy, Yves. "Government of New Caledonia representative.” Interview by Simon Lovatt, February 14, 2011.

Lees, A., and S. Siwatibau. Review and analysis of Fiji's conservation sector. The Austral Foundation, November 2007. http://australfoundation.org/Final report PDF Lees.pdf.

. "Strategies for Effective and Just Conservation: A Summary of the Austral Foundation's Review of Conservation in Fiji." Current Conservation 3, no. 3 (2009): 21-23.

Lowe, S, M Browne, S Boudjelas, and M De Poorter. 100 of the World's Worse Invasive Alien Species: A selection from the Global Invasive Species Database. Auckland, New Zealand: The Invasive Species Specialist Group (ISSG), 2004. http://www.issg.org/pdf/publications/worst_100/english_100_worst.pdf.

MAF Biosecurity New Zealand. “About Us - Our Organisation,” November 21, 2008. http://www.biosecurity.govt.nz/biosec/org.

_. Balance in Trade: Understanding how the Sanitary and Phytosanitary (SPS) Agreement helps protect New Zealand's people, economy and environment while improving trade opportunities. Wellington, New Zealand: Ministry of Agriculture and Forestry, 2009. http://www.biosecurity.govt.nz/files/biosec/policylaws/intl/sps/resources/new-zealand/balance-in-trade.pdf.

___. "Common wasp," October 22, 2008. http://www.biosecurity.govt.nz/pests/commonwasp.

___. "Didymosphenia geminata Economic Impact Report-March 2006," April 30, 2008. http://www.biosecurity.govt.nz/pests-diseases/plants/didymo/economic-impact.htm.

___. "History of the Strategy," October 16, 2008.

http://www.biosecurity.govt.nz/biosec/sys/strategy/biostrategy/history. 
__ . "Importing Ballast Water from all Countries," June 13, 2005.

http://www.biosecurity.govt.nz/imports/non-organic/standards/ballastwater.htm.

___. "Pacific Programmes," September 7, 2010.

http://www.biosecurity.govt.nz/biosec/pacific-portal/programmes.

__ . "The battle for the Pacific: Keeping invasive ants at bay," April 30, 2008. http://www.biosecurity.govt.nz/publications/biosecurity-magazine/issue-77/pacific.

___ "The Biosecurity System," December 17, 2010. http://www.biosecurity.govt.nz/biosec/sys.

—_. "Varroa Mite," June 30, 2009. http://www.biosecurity.govt.nz/pests/varroa.

Masamdu, Roy. Letter to Simon Lovatt. "Secretariat of the Pacific Community (SPC)," February 11, 2011.

McGeoch, M. A, S. H.M Butchart, D. Spear, E. Marais, E. J Kleynhans, A. Symes, J. Chanson, and M. Hoffmann. "Global indicators of biological invasion: species numbers, biodiversity impact and policy responses." Diversity and Distributions 16, no. 1 (2010): 95-108.

McIntyre, M. Pacific Environment Outlook - Special Edition for the Mauritius International Meeting for the 10-year Review of the Barbados Programme of Action for the Sustainable Development of Small Island Developing States. United Nations Environment Programme (UNEP), 2005. http://www.unep.org/pdf/sids/Pacific_EO_final.pdf.

McNeely, J. "Invasive species: a costly catastrophe for native biodiversity." Land Use and Water Resources Research 1, no. 2 (2001): 1-10.

McNeely, J. A., H. A. Mooney, L. E. Neville, P. J. Schei, and J. K. Waage, eds. A global strategy on invasive alien species. Gland, Switzerland, and Cambridge, UK: IUCN, 2001.

Meyerson, L. A, and H. A Mooney. "Invasive alien species in an era of globalization." Frontiers in Ecology and the Environment 5, no. 4 (2007): 199-208.

Millennium Ecosystem Assessment. Ecosystems and Human Well-being: Synthesis. Washington D.C.: Island Press, 2005. http://www.maweb.org/documents/document.356.aspx.pdf.

Ministry of Agriculture and Forestry (MAF). "Our Structure," January 14, 2011. http://www.maf.govt.nz/about-maf/our-organisation/our-structure.

Ministry of Foreign Affairs and Trade (MFAT). "Pacific Security Fund," July 13, 2010. http://www.mfat.govt.nz/Foreign-Relations/Pacific/Regional-Security/0-pacsecfund.php.

Ministry of Primary Industries. "Silent and sinister - is the American iguana here to stay?," December 2, 2010.

http://www.agriculture.org.fj/index.cfm?si=main.resources\&cmd=forumview\&cbegin=0 \&uid=aigcampaign\&cid=1393.

Minteer, Carey. "I am a Bird Watcher. Why should I care about invasive species?," February 24, 2010. http://www.invasive.org/101/BirdWatcher.html.

Moloney, S., and C. Vanderwoude. "Red Imported Fire Ants: A threat to eastern Australia's wildlife?." Ecological Management \& Restoration 3, no. 3 (2002): 167-175.

Naidu, V. "Changing Gears on the Millennium Development Goals in Oceania." Policy Quarterly 5, no. 3 (August 2009): 10-19. 
New Caledonia. Agenda Item 11.1: Mainstreaming invasive species and biodiversity. Working Paper. Madang, Papua New Guinea: SPREP, June 14, 2010.

http://www.sprep.org/2010SM21/pdfs/eng/Officials/WP_11_1_NC

paper_Mainstreaming Invasive species and biodiversity.pdf.

New Zealand Agency for International Development (NZAID). Pacific Strategy 2007-2015:

Te Ara Tupu - the pathway of growth / Tackling Poverty in our Region. Wellington, New Zealand: NZAID, June 2008. http://www.aid.govt.nz/programmes/wln-pacificregional-strategy-2007-2015-full-june08.pdf.

New Zealand Aid Programme. "New Zealand NGO contestable funds," n.d. http://www.aid.govt.nz/what-we-do/nz-ngo-contestable-funds.html.

__ . "New Zealand State Sector Development Partnerships Fund," n.d. http://www.aid.govt.nz/what-we-do/dpf.html.

—_. "Pacific countries overview," n.d. http://www.aid.govt.nz/programmes/c-paccountries.html.

___ "Pacific Island Countries Participation Fund," n.d. http://www.aid.govt.nz/pic/.

New Zealand Biodiversity. "Pests and weeds," n.d.

https://www.biodiversity.govt.nz/picture/biodiversity/state/pests.html.

__. "Why we value biodiversity," n.d.

https://www.biodiversity.govt.nz/picture/biodiversity/why.html.

3 News. "Imports of NZ kiwifruit cuttings banned," November 10, 2010.

http://www.3news.co.nz/Imports-of-NZ-kiwifruit-cuttings-

banned/tabid/423/articlelD/185663/Default.aspx.

OECD Development Assistance Committee (DAC). Measuring aid targeting the objectives of the Rio Conventions. OECD, May 2009. http://www.oecd.org/dataoecd/46/13/42819225.pdf.

__. "New Zealand (2010) DAC Peer Review: Main Findings and Recommendations," 2010.

http://www.oecd.org/document/54/0,3746,en_21571361_37949547_46730038_1_1_1 _1,00.html.

Orapa, Warea. Letter to Simon Lovatt. "Secretariat of the Pacific Community (SPC)," January 17, 2011.

Organisation for Economic Co-operation and Development (OECD). Table 1: Net Official Development Assistance In 2009. OECD, April 14, 2010. http://www.oecd.org/dataoecd/17/9/44981892.pdf.

Overton, John. "The aid industry in New Zealand." Journal of International Education in Business 1, no. 1 (February 2010): 27-48.

Pacific Invasive Ant Group (PIAG). Pacific Ant Prevention Plan. Pacific Plant Protection Organisation and Regional Technical Meeting For Plant Protection, March 2004. http://www.issg.org/database/species/reference_files/PAPP.pdf.

Pacific Invasives Initiative (PII), February 24, 2011. http://www.issg.org/cii/pii/index.html.

- Invasive Species Management in the Pacific: A Review of National Plans and Current Activities. Auckland, New Zealand: Pacific Invasives Initiative, September 2010.

___. "Pacific-wide: Pacific Ant Prevention Programme (PAPP)," October 16, 2009. http://www.issg.org/cii/pii/demo/papp.html. 
—_. The News, November 2008.

http://www.issg.org/cii/Electronic\%20references/pii/PII_News/2008/0811 PII News.pdf.

— . The PII News, December 2010. http://www.issg.org/cii/Electronic

references/pii/PII_News/2010/the_pii_news_dec_2010.pdf.

_- "Tokelau: Nukunonu and Fakaofo Atolls -

Yellow crazy ant (Anoplolepis gracilipes)," July 6, 2009.

http://www.issg.org/cii/PII/demo/tokelauAnt.html.

Pacific Invasives Learning Network (PILN), January 2011. http://www.sprep.org/piln/.

Pacific Islands Forum Secretariat. "Council of Regional Organisations in the Pacific (CROP) Charter," April 2000. http://www.spc.int/Coastfish/CROPcharter.htm.

—_. Pacific Plan 2010 Annual Progress Report. Pacific Islands Forum, 2010. http://www.forumsec.org/resources/uploads/attachments/documents/Pacific Plan 2010 Annual Progress Report_Eng.pdf.

- The Pacific Plan - for strengthening regional cooperation and integration. Port Moresby, PNG: Pacific Islands Forum, 2007.

http://www.forumsec.org.fj/resources/uploads/attachments/documents/Pacific_Plan_N ov_2007_version.pdf.

Pagad, Shyama. "Invasive Species Specialist Group (IUCN-ISSG)." Interview by Simon Lovatt, February 9, 2011.

Paini, D. R, S. P Worner, D. C Cook, P. J De Barro, and M. B Thomas. "Threat of invasive pests from within national borders." Nature Communications 1, no. 115 (2010): 1-6.

Pennefather, Gary. Letter to Simon Lovatt. "New Zealand Defence Force (NZDF)," February 11, 2011.

Perrings, C., K. Dehnen-Schmutz, J. Touza, and M. Williamson. "How to manage biological invasions under globalization." Trends in Ecology \& Evolution 20, no. 5 (2005): 212215.

Perrings, C., M. Williamson, E. B Barbier, D. Delfino, S. Dalmazzone, J. Shogren, P. Simmons, and A. Watkinson. "Biological invasion risks and the public good: an economic perspective." Conservation Ecology 6, no. 1 (2002): 1.

Perrings, Charles. "The economics of biological invasions." Land Use and Water Resources Research 1, no. 3 (2001): 1-9.

Pfeiffer, J. M, and R. A Voeks. "Biological invasions and biocultural diversity: linking ecological and cultural systems." Environmental Conservation 35, no. 04 (2008): 281293.

Pimentel, D., S. McNair, J. Janecka, J. Wightman, C. Simmonds, C. O'connell, E. Wong, et al. "Economic and environmental threats of alien plant, animal, and microbe invasions." Agriculture, Ecosystems \& Environment 84, no. 1 (2001): 1-20.

Pimentel, D., R. Zuniga, and D. Morrison. "Update on the environmental and economic costs associated with alien-invasive species in the United States." Ecological Economics 52, no. 3 (2005): 273-288.

Plummer, Mary Anne. "Farming Systems Project: Samoa." AusAID, n.d. http://www.ausaid.gov.au/publications/focus/focuspdfs/997/99729.pdf.

Pyšek, P., V. Jarošík, P. E Hulme, I. Kühn, J. Wild, M. Arianoutsou, S. Bacher, et al. "Disentangling the role of environmental and human pressures on biological invasions across Europe." Proceedings of the National Academy of Sciences 107, no. 27 (2010): 12157. 
Radio New Zealand International. "Samoa resumes taro export after blight debacle," July 7, 2010. http://www.rnzi.com/pages/news.php?op=read\&id=54570.

Reaser, Jamie, Brooks Yeager, Paul Phifer, Alicia Hancock, and Alexis Gutierrez. "Environmental Diplomacy and the Global Movement of Invasive Alien Species: A U.S. Perspective." In Invasive species: vectors and management strategies, edited by Gregory M. Ruiz and James T. Carlton, 362-381. Washington D.C.: Island Press, 2003.

Roundtable for Nature Conservation in the Pacific Islands. "Roundtable Home," n.d. http://www.sprep.org/Roundtable/.

Sanu, Praseeda, and Jeyanth Newport. "Invasive alien species dispersal: the millennium biodiversity disaster." Disaster Prevention and Management 19, no. 3 (2010): 291297.

Saunders, Alan. "Landcare Research." Interview by Simon Lovatt, January 25, 2011.

Schmidt, K. A, and C. J Whelan. "Effects of exotic Lonicera and Rhamnus on songbird nest predation." Conservation Biology 13, no. 6 (1999): 1502-1506.

Secretariat of the Pacific Community (SPC), 2010. http://www.spc.int/.

"SPC will be a 'larger organisation' in 2011," October 28, 2010.

http://www.spc.int/en/component/content/article/613-spc-will-be-a-larger-organisationin-2011-.html.

—_. "Welcome to the Plant Protection Service Homepage," May 12, 2008. http://www.spc.int/pps/.

Secretariat of the Pacific Regional Environment Programme (SPREP), 2010. http://www.sprep.org/.

- 2009 Annual Report of the Secretariat of the Pacific Regional Environment Programme (SPREP). Apia, Samoa: SPREP, 2010. http://www.sprep.org/att/publication/000865_SPREP_ANNUAL_REPORT_2009.pdf.

- Action Strategy for Nature Conservation and Protected Areas in the Pacific islands region 2008-2012: empowering local people, communities and Pacific institutions. Apia, Samoa: Roundtable for nature conservation in the Pacific Islands, 2009. http://www.sprep.org/att/publication/000755_RoundtableActionStrategy.pdf.

__. Agenda Item 6.1: SPREP Strategic Plan 2011 - 2015. Madang, Papua New Guinea: SPREP, September 2010.

http://www.sprep.org/2010SM21/pdfs/eng/Officials/WP_6_1_Strategic Plan 20112015.pdf.

___ "Factsheet: Invasive Species," n.d.

http://www.sprep.org/factsheets/invasives/index.htm.

__ . "Factsheet: Pacific Climate Change," n.d.

http://www.sprep.org/factsheets/climate/index.htm.

___. "Pacific Environment Ministers' Communique," September 9, 2010. http://www.sprep.org/article/news_detail.asp?id=822.

. Pacific Islands Action Plan on Climate Change 2006-2015. Apia, Samoa: SPREP, n.d. http://www.sprep.org/legal/documents/APClimateChange.pdf.

Pacific Islands Framework for Action on Climate Change 2006-2015. Apia, Samoa: SPREP, n.d. http://www.sprep.org/climate_change/pycc/documents/PIFACC.pdf. 
- Secretariat of the Pacific Regional Environment Programme (SPREP) Strategic Plan : 2011-2015. Apia, Samoa: SPREP, 2011.

http://www.sprep.org/att/publication/000911_SPREP_Strategicplan_2011_2015.pdf.

Senate Foreign Affairs, Defence and Trade Committee. A Pacific engaged. Australia's relations with Papua New Guinea and the island states of the south-west Pacific (Chapter 9). Canberra, Australia: Parliament of Australia, August 12, 2003. http://www.aph.gov.au/Senate/committee/fadt_ctte/completed_inquiries/200204/png/report/c09.pdf.

Sheppard, Brian. "Helping Islands Adapt," 2010. http://www.conference.co.nz/isw10.

Sheppard, David. "Building Resilience to Climate Change in the Pacific" presented at the Resilience in the Pacific: Addressing the Critical Issues, Wellington, New Zealand, February 17, 2011. http://ips.ac.nz/events/downloads/2011/Pacific Resilience presentations/Session 6 david sheppard.pdf.

—_. "Pacific Biodiversity National Reports," April 4, 2010. http://www.sprep.org/article/news_detail.asp?id=758.

Shine, Clare, Nattley Williams, and Lothar Gündling. A guide to designing legal and institutional frameworks on alien invasive species. Environmental policy and law paper. IUCN environmental policy and law paper. Gland, Switzerland,: International Union for Conservation of Nature (IUCN), 2000. http://data.iucn.org/dbtw-wpd/edocs/EPLP-040En.pdf.

Space, James, Barbara Waterhouse, Melanie Newfield, and Cate Bull. Report to the Government of Niue and the United Nations Development Programme: Invasive Plant Species on Niue following Cyclone Heta. United Nations Development Programme (UNDP), December 17, 2004. http://www.sprep.org/att/IRC/eCOPIES/INVASIVE SPECIES/niue.pdf.

SPC Land Resources Division. "SPC assists Fiji in efforts to manage the termite problem," August 5, 2010.

http://www.spc.int//rd/index.php?option=com_content\&view=article\&id=496:taropest\&c atid $=23 \&$ Itemid $=18$.

Steiner, Achim. "Counting the cost of alien invasions," April 13, 2010. http://news.bbc.co.uk/2/hi/science/nature/8615398.stm.

Stern, N. The Economics of Climate Change: the Stern Review (Executive Summary). London, UK: HM Treasury, 2006.

http://siteresources.worldbank.org/INTINDONESIA/Resources/2262711170911056314/3428109-1174614780539/SternReviewEng.pdf.

Storey, D., H. Bulloch, and J. Overton. "The poverty consensus: some limitations of the 'popular agenda'." Progress in Development Studies 5, no. 1 (2005): 30-44.

The Centre for Biodiversity and Biosecurity. "Island Invasives: Eradication and Management Conference," February 23, 2010. http://www.cbb.org.nz/conferences.asp.

The Economics of Ecosystems and Biodiversity (TEEB). TEEB for National and International Policy Makers. Summary: Responding to the Value of Nature, 2009. http://www.teebweb.org/Portals/25/Documents/TEEB for National Policy Makers/TEEB for Policy exec English.pdf.

. The Economics of Ecosystems and Biodiversity: An Interim Report. Brussels, Belgium: European Communities, 2008. http://www.unep.ch/etb/publications/TEEB/TEEB_interim_report.pdf. 
The Food Secure Pacific Working Group. Towards A Food Secure Pacific: Framework for Action on Food Security in the Pacific. Fiji: Food Secure Pacific, June 1, 2010. http://www.foodsecurepacific.org/documents/FINAL TOWARDS A FOOD SECURE PACIFIC_June1.pdf.

The Ramsar Convention on Wetlands, n.d. http://www.ramsar.org/cda/en/ramsarhome/main/ramsar/1_4000_0

___ "Resolution VII.14: Invasive species and wetlands," May 1999. http://www.ramsar.org/cda/en/ramsar-documents-resol-resolution-vii14/main/ramsar/1-31-107\%5E20830_4000_0_.

___ "Resolution VIII.11: Additional guidance for identifying and designating underrepresented wetland types as Wetlands of International Importance," November 2002. http://www.ramsar.org/cda/en/ramsar-documents-resol-resolution-viii11/main/ramsar/1-31-107\%5E21521_4000_0_.

Thomson, S. "Aid Directions for Depression Days." New Zealand International Review 34, no. 4 (2009): 16-18.

Townsend, C.R., and K.S. Simon. "Consequences of Brown Trout Invasion for Stream Ecosystems." Biological Invasions in New Zealand 186 (2006): 213-225.

Tye, Alan. Guidelines for invasive species management in the Pacific: a Pacific strategy for managing pests, weeds and other invasive species. Apia, Samoa: SPREP, 2009. http://www.sprep.org/att/publication/000699_RISSFinalLR.pdf.

_- "Secretariat of the Pacific Regional Environment Programme (SPREP)." Interview by Simon Lovatt, January 21, 2011.

United Nations. "Preserving Biodiversity Vital For Economic Growth," February 12, 2010. http://www.scoop.co.nz/stories/WO1002/S00300.htm.

United Nations Development Programme (UNDP). Human Development Index and its components. UNDP, 2010. http://hdr.undp.org/en/media/HDR_2010_EN_Tables_reprint.pdf.

United Nations Environment Programme (UNEP). "Environment for Development," n.d. http://www.unep.org/.

University of French Polynesia. "Creation of the Great Observatory of South Pacific Environment and Land \& Ocean Biodiversity," December 14, 2010. http://webdevel.upf.pf/Creation-of-the-Great-Observatory.html?lang=en.

University of the South Pacific (USP), 2011. http://www.usp.ac.fj/.

___. "Institute of Applied Science," October 14, 2010. http://ias.fste.usp.ac.fj/.

USDA Forest Service - Southern Research Station. "Invasive tallowtree spreading rapidly across Gulf coast," October 6, 2010.

http://www.sciencedaily.com/releases/2010/06/100608135038.htm.

Walrond, Carl. "Acclimatisation - Improving upon nature -." Te Ara Encyclopedia of New Zealand, March 2009. http://www.teara.govt.nz/en/acclimatisation/1.

World Bank. Convenient Solutions to an Inconvenient Truth: Ecosystem-based Approaches to Climate Change. Washington D.C.: World Bank, June 2009.

http://siteresources.worldbank.org/ENVIRONMENT/Resources/ESW_EcosystemBase dApp.pdf.

World Trade Organisation (WTO). "The WTO Agreement on the Application of Sanitary and Phytosanitary Measures (SPS Agreement)," n.d.

http://www.wto.org/english/tratop_e/sps_e/spsagr_e.htm. 
World Trade Organization (WTO), n.d. http://www.wto.org/. 


\section{Appendix A: Ethics approval}

TE WHARE WĀNANGA O TE ŪPOKO O TE IKA A MĀUI

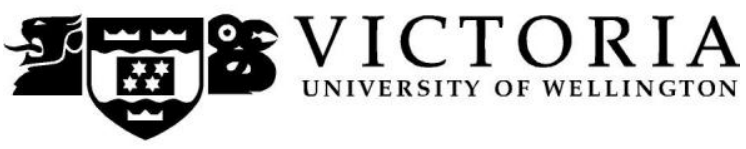

MEMORANDUM

Phone 0-4-463 5676

Fax $\quad 0-4-4635209$

Email_Allison.kirkman@vuw.ac.nz

\begin{tabular}{l|l}
\hline TO & Simon Lovatt \\
\hline COPY TO & John Leslie \\
\hline FROM & Dr Allison Kirkman, Convener, Human Ethics Committee \\
\hline
\end{tabular}

\begin{tabular}{l|l}
\hline DATE & 10 January 2011 \\
\hline PAGES & 1 \\
\hline
\end{tabular}

\begin{tabular}{l|l}
\hline SUBJECT & $\begin{array}{l}\text { Ethics Approval: No 18222 New Zealand and invasive species } \\
\text { control in the Pacific - are the methods used appropriate and } \\
\text { effective for small islands }\end{array}$ \\
\hline
\end{tabular}

Thank you for your application for ethical approval, which have now been considered by the Standing Committee of the Human Ethics Committee.

Your application has been approved from the above date and this approval continues until 31 May 2011. If your data collection is not completed by this date you should apply to the Human Ethics Committee for an extension to this approval.

Best wishes with the research.

Allison Kirkman

Human Ethics Committee 


\section{Appendix B: Participant Information Sheet}

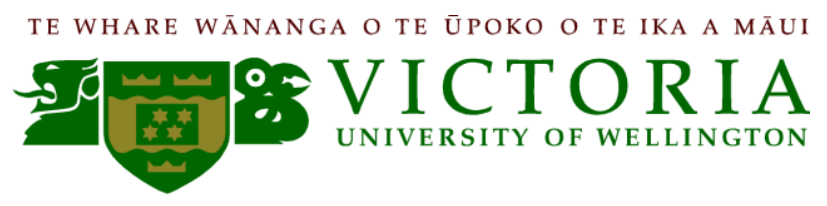

\section{RESEARCH PROJECT INFORMATION SHEET}

Title of project: New Zealand and invasive species control in the Pacific - are the methods used appropriate and effective for small island states

Researcher: Simon Lovatt, School of History, Philosophy, Political Science and International Relations, Victoria University of Wellington

I am a Masters student in International Relations at Victoria University of Wellington. As part of this degree I am undertaking a research project. This project aims to investigate the appropriateness and effectiveness of New Zealand's support for invasive species control in the South Pacific, and does this work aligns with the Principles of the Roundtable for Nature Conservation in the Pacific's Action Strategy for Nature Conservation and Protected Areas in the Pacific Island Region 2008-2012 such as ensuring local ownership and building local capacity for the long-term sustainability of projects. This project has ethics approval from the university Human Ethics Committee.

I intend to conduct a short (30 minutes - 1 hour) interview either over the telephone or at a location that is convenient for the participants. I will digitally record the interviews, and also take notes as the interview progresses. Participation is voluntary and all material collected will be kept confidential. No other person besides me and my supervisor, Dr John Leslie, will see the interview transcripts. Opinions will be attributed to the interviewee (and their organisation). Participants can withdraw from this project if they wish to do so up to 3 weeks after an interview has taken place.

This project will be submitted for marking to the School of History, Philosophy, Political Science and International Relations. It is intended that one or more articles will be submitted for publication in scholarly journals. Interview transcripts will be stored in a locked file and destroyed two years after the end of the project.

If you have any questions or would like to receive further information about the project, please contact me at simon.lovatt@gmail.com or my supervisor, Dr John Leslie, at the School of History, Philosophy, Political Science and International Relations at Victoria University, P O Box 600, Wellington, phone +64 44639494 .

Simon Lovatt 


\section{Appendix C: Participant Consent Form}

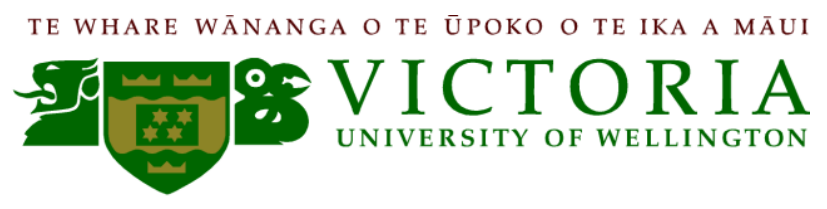

\section{CONSENT TO PARTICIPATION IN RESEARCH}

Title of project: New Zealand and invasive species control in the Pacific - are the methods used appropriate and effective for small island states?

I have been given and have understood an explanation of this research project. I have had an opportunity to ask questions and have them answered to my satisfaction. I understand that I may withdraw myself (or any information I have provided) from this project (up to 3 weeks after my interview) without having to give reasons.

I consent to information or opinions which I have given being attributed to me in any reports on this research. I also consent to my organisation's name to be used in any reports on this research. I understand that the data I provide will not be used for any other purpose or released to others without my written consent.

I would like to receive a summary of the results of this research when it is completed.

Signed:

Name of participant

Email address

(Please print clearly)

Date:

Please email a scanned copy of the completed form to simon.lovatt@gmail.com; or a fax addressed to Simon Lovatt on +64 44635414 . 


\section{Appendix D: Sample Interview Questions}

- Why is controlling invasive species important?

- Which invasive species are the most important to the Pacific, and also to donors?

- How important are invasive species compared to other development goals (such as education, health, or climate change)?

- Which is more of a concern with controlling invasive species - development issues or biodiversity conservation issues?

- What is your organisation's role in invasive species management in the Pacific?

- How do New Zealand agencies interact with your organisation?

- Does your organisation have contact with other donors in the region for invasive species management?

- Why do you think New Zealand agencies want to assist with invasive species management in the Pacific?

- How much national or community involvement is there in invasive species management project design and implementation?

- Are projects allowed enough time and funding to be successful?

- Do you have any successful case studies? Any unsuccessful case studies?

- Can you think of any problems that might occur with using New Zealand invasive species management methods?

- What would you like to see change with invasive species management in the Pacific, and also with New Zealand's assistance? Is there a cost if this doesn't happen? 


\section{Appendix E: Participants}

- Souad Boudjelas, Pacific Invasives Initiative (PII)

- Keith Broome, Island Eradication Advisory Group (IEAG), Department of Conservation (DOC)

- Stanley Burgiel, National Invasive Species Council (NISC)

- Kevin Clark, former consultant, Pacific Invasives Initiative (PII)

- Bernd Cordes, The David and Lucile Packard Foundation

- Paul Eastwood and Willy Morrell, International Development Group, Ministry of Foreign Affairs and Trade (IDG MFAT)

- Kennedy Graham, MP, Green Party of Aotearoa New Zealand

- Sally Jennings, Biosecurity New Zealand, Ministry of Agriculture and Forestry

- Yves Lafoy, Government of New Caledonia representative

- Roy Masamdu, Secretariat of the Pacific Community (SPC)

- Warea Orapa, Secretariat of the Pacific Community (SPC)

- Shyama Pagad, Invasive Species Specialist Group, International Union for Conservation of Nature (IUCN-ISSG)

- Gary Pennefather, New Zealand Defence Force (NZDF)

- Alan Saunders, Landcare Research

- Alan Tye, Secretariat of the Pacific Regional Environment Programme (SPREP) 